\title{
NEW SPECIES OF DREPANULIDAE, THYRIDIDAE, URANIIDAE, EPIPLEMIDAE, AND GEOMETRIDAE IN THE TRING MUSEUM.
}

\author{
By W. WARREN, M.A., F.E.S.
}

\section{FAMILY DREPANULIDAE.}

\section{Albara humerata sp. nov.}

Forewings: fawn-colour, the costal edge from base to middle yellowish; the lines ferruginous, starting from dark brown costal spots; first at one-fourth, oblique outwards, angled on the subcostal, then straight and vertical or slightly oblique to inner margin beyond one-third; second line from costa at middle, runs outward along the subcostal vein for two-thirds of the distance to the apex, is then sharply angulated, incurved opposite the cell and outcurved below it, reaching the inner margin straight at four-fifths; submarginal line strongly denticulate, blackish; marginal area dark grey, with some irregular black marks before the fringe, which is chestnut with a pale basal line; apical one-third of costa with a chestnut streak, the apex itself with one or two snow-white spots; cell-spot large, blackish, followed obliquely below it by four small white spots edged with black, and sometimes altogether black.

Hindwings: fawn-colour, in the $q$ with the costal area ochreous; in the $\delta$ with the ochreous tint suffusing the wing and leaving only the inner and anal margins fawn-colour; a curved postmedian line, abbreviated in the $\delta$, reaching to the ochreous costal part in the $q$, which also has a short antemedian line on inner margin which is wanting in the $\delta$.

Underside glossy yellow, in the forewings more or less suffused with grey. Face and palpi blackish; fillet and antennae purple-black; collar ferruginous; thorax and abdomen fawn-colour; legs and abdomen beneath yellow; the forelegs fuscous-tinged.

Expanse of wings : $22-24 \mathrm{~mm}$.

Many examples from the Khasias, dated Nay, September, and December. Distinguished by the strongly arched base of costa of the forewings.

\section{Cobanilla jaspidea sp. nov.}

Forewings: red, the basal and outer areas tinged with paler and ochreous; first line at one-third, dark red, curved below costa and oblique inwards; basal area varied with ochreous and darker reticulations, the costal portion rosy; second line from costa at three-fourths, sharply angled outwards towards apex, then oblique to inner margin beyond middle, before which it is slightly bent, dark purple, edged with whitish scales; cell-spot lunulate, red with paler centre and surrounded by a bronzy orange patch; marginal area beyond second line pinkish ochreous with a few dark reticulations, becoming deep red again along hindmargin ; apex marked with black. 
Hindwings: with the bronzy orange patch larger, edged by an angulated line; the disc and inner margin spotted with patches of white scales; the outer area towards costa with dark spots between the veins; fringe of both wings deep red.

Underside fulvous, spotted with fuscous; the oblique line and anal angle of forewings deep brown. Face, palpi, and forelegs bright red; thorax paler ; abdomen deep red.

Expanse of wings: $48 \mathrm{~mm}$.

One $q$ from Cedar Bay, south of Cooktown, Qneensland (A. S. Meek).

\section{Drapetodes interlineata sp. nov.}

Forewings: pale brownish ochreous, the costal edge white; a subcostal line of shining black scales from middle of base to near apex, before which it is bent at right angles and waved to third median, and again bent and oblique to inner margin before middle; in the lower part and along the waved apical portion it has a broad pale inner edge; between the two lines are two similar brownish lines from inner margin nearer base, waved before apex; a very fine dark lunulate submarginal line from apex, marked with black dots on veins, divergent inwards from the margin above anal angle, to inner margin at three-fourths, and there thicker; fringe concolorous, with a fine dark line; some black streaks on costa at base and before apex; two black discocellular dots.

Hindwings: crossed by a succession of straight lines; basal area pale; two dark antemedian lines enclosing a brown fascia with a line along its centre; a pale fascia with the black cell-dot in it, edged by a brown line; exterior line black, finely crenulate, with a pale broad inner edge, preceded and followed by a pair of brown lines; submarginal line straight, dark, the margin beyond it darker; fringe with a fine dark basal line.

Underside pale ochreous, with only the outer lines shown. Face and palpi ochreous below, red-brown above; thorax and abdomen brownish ochreous.

Expanse of wings: $\delta, 24 \mathrm{~mm}$; ; , $26 \mathrm{~mm}$.

A pair from South Java, 1891; 1500 feet (Fruhstorfer).

The antennae of the $\delta$ are not only thickened and flattened, but uniserrate, the teeth curved and close together.

\section{Drapetodes lunulata sp. nov.}

Forewings: brownish ochreous; the inner margin at base and an oblique streak from apex to middle of inner margin ochreous yellow; some darker brown irregular streaks on inner area, oblique outwards from costa and inwards to inner margin; the pale streak towards apex is crossed by two series of strongly sagittiform brown markings, succeeded by six broad whitish lunular marks, the last three lying in an oblique line to the inner margin; a triangular space at anal angle dark grey-brown; marginal line dark brown; fringe chequered pale and dark ochreous.

Hindwings: with basal area yellowish, crossed by two brown lines; median area greyish ochreous, with two black discal spots and a postmedian darker line; marginal space narrowly dark grey, broadening towards anal angle, preceded by a cow of large irregular yellow lunules, each edged internally by a paler brown-edged crescentic mark; fringe ochreous grey, with slight pale markings. 
Thorax and abdomen ochreous brown, the latter whitish at sides; face and vertex pale ochreous. Underside cream-colour; the fringe and some submarginal spots greyish.

Expanse of wings : $30 \mathrm{~mm}$.

One $\&$ from West Java.

\section{Euchera absentimacula sp. nov.}

Nearest to substigmaria Hub., from which it is at once distinguished by the entire absence of the round cell-spot in both wings, above and below; in its place on the upperside of forewings is a flattened oval oblique pale spot. All the grey markings are rufous-tinged, especially those towards apex of forewings; the edge of the basal area and the inner edge of the central fascia, after angulation on the subcostal, descend nearly vertically to inner margin, instead of being oblique and curved; the outer edge of central fascia opposite the cell is blunt and vertically waved, not oblique and angulated; and the exterior wavy line is complete throughout, the marginal area coloured with rufous grey. The hindwings are without any dark suffusion or blotches on the outer line towards apex. On the underside the costal region of forewings is broadly tinged with rufous grey. The same size as substigmaria.

One $\delta$, one $q$, from Java.

\section{Gonocilix gen. nov.}

Forewings: with costa arched; apex slightly produced, blunt; hindmargin angled at vein 4 , with a shallow excision above and below; anal angle distinct.

Hindwings : with apex rounded; anal angle square; hindmargin bluntly toothed at vein 4 .

Antennae thickened and flattened; palpi porrect, not reaching beyond face; tongue and frenulum present.

Neuration: discocellular strongly inangulated; the first subcostal free, running close to second; second anastomosing with stem of third and fourth, forming a long areole; the fifth subcostal given off just before the end of areole; the upper radial from the areole. Hind tibiae with four spurs.

Type: Gonocilix ocellata sp. nov.

\section{Gonocilix ocellata sp. nov.}

Forewings: white, the markings blue-grey; first line at one-fourth, marked by three blotches, one on costa, another in the submedian interspace, the third on inner margin ; at end of cell is a large oblique oval pale olive blotch, edged outwardly with fuscous brown, the veins within it silvery white, an oblique costal blotch above it, and a larger diffuse one beyond it; a silvery white streak on the inner edge of the ocellus is continued to inner margin as an olive double streak, the branches of which are divergent ; a subapical costal blotch and submarginal blue-grey band of partially connected spots; a marginal row of dark grey blotches, continued into the paler grey fringe, which has a fine white basal line and is chequered with white at the ends of the veins, and is altogether white at apex and anal angle; between veins 2 and 3 beyond the ocellus is a round hyaline space, and three or four more in the submarginal band, that at the top, beneath the subapical blotch, the largest.

Hindwings: with a double basal line; an ocelloid blue-grey blotch, containing 
first a white line, then the veins silvery, tipped with black, and followed by three hyaline patches; the rest as in forewings.

Underside silvery white, blotehed with cinereous brown, most extensively in forewings. Face and palpi brown; thorax and abdomen white, the latter with the three middle and anal segments marked with blue-grey.

Expanse of wings: $\delta, 36 ;$ ㅇ, $48 \mathrm{~mm}$.

A pair from the Khasia Hills.

\section{Oreta fuscimargo sp. nov.}

Forewings: yellow, tinged with rosy in parts; no first line; a slightly darker cloud on the discocellular; hindmargin tinged with red and darkened by purple and grey scales, with a darker blotch below the middle; an obscure fine reddish line from before apex to inner margin beyond middle.

Hindwings: with the red line central and plainer; traces of an antemedian line; the area between the two tinged with rosy, and the apex also reddish; fringe yellow, but red at apex; altogether dark red in forewings.

Underside glossy yellow; forewings with a brown marginal band. Face, pectus, and forelegs red; thorax and abdomen yellow.

Expanse of wings : $26 \mathrm{~mm}$.

One $q$ from Coomooboolaroo, Duaringa, North Queensland (A. S. Meek).

The antennae are densely serrate.

\section{Phalacra strigata sp. nov.}

Forewings: ochreous, suffused and dusted with pale brownish; a double angulated line at one-third, the inner arm marked by brown spots on the veins, the outer by brown blotches; from the middle of the discocellular a straight brown striga runs to the hindmargin; three brown subapical costal spots, from each of which runs a curved series of vein-dots, those before the margin the largest; a brown blotch at anal angle; fringe ochreous, chequered with brown.

Hindwings: with four or five very faint parallel lines before the middle, and eight in the marginal area; of these last, the second, third, and fourth are distinct; the submarginal one marked with brown dots on the veins; a brown dot at each end of the discocellular, and some brown costal spots; hindmargin excised below apex and with a tooth below third median.

Underside darker, with interrupted brown submarginal fasciae to each wing; space on inner margin between middle line and fascia whitish; this is also visible on the upperside. Face and palpi blackish; head, thorax, and abdomen ochreous.

Expanse of wings : $42 \mathrm{~mm}$.

One $\delta$ from Cherrapunji, December.

\section{Teldenia obsoleta sp. nov.}

Forewings: white; a pale ochreous waved line, formed of small lunules near hindmargin ; faint traces of ochreous lunules, indicating an exterior line, below costa and in middle; fringe white, with concise black spots between the veins at base.

Hindwings: like forewings, without any trace of an exterior line.

Underside pure white. Palpi and upper half of face red-brown; lower half white; vertex, thorax, and abdomen white.

Expanse of wings : $23 \mathrm{~mm}$.

One $\delta$ from Dili, Timor, May 1892 (W. Doherty). 
10. Teldenia unistrigata sp. nov.

Forewings: white, the costa narrowly pale ochreous; a curved ochreous line from two-thirds of costa to four-fifths of inner margin ; fringe white.

Hindwings: with the ochreous line parallel to hindmargin, at four-fifths.

Underside white, without markings. Face, vertex, and palpi dark brown; thorax and abdomen white.

Three $\delta$ \& from Padang Rengas, Perak, Malay Peninsula.

Expanse of wings : $20 \mathrm{~mm}$.

\section{Tridrepana argentistriga sp. nov.}

Forewings: yellow, the outer half with pale red-brown suffusion; a dark redbrown oblique line from before apex to middle of inner margin, meeting there a vertical line which becomes obsolete at the median; an irregularly wavy red-brown submarginal line, its upper half edged externally with silvery white; fringe deep red-brown.

Hindwings: wholly yellow, the oblique line antemedian; a fine threadlike postmedian line; an oval silvery spot at lower end of discocellular, and a fine linear one at the upper end; fringe yellow.

Underside pale yellow, the forewings flushed with reddish, with an abbreviated oblique line and some submarginal spots red-brown. Face bright red above, yellowish below; thorax and abdomen yellow, the latter with a red ring across second segment.

Expanse of wings: $32 \mathrm{~mm}$.

One $\delta$ from Mt. Mulu, North Borneo (1000-4000 feet).

Near to postica Moore and xanthoptera Hmpsn.

\section{Tridrepana septempunctata sp. nov.}

Forewings: rich fulvous, except the base and a patch at anal angle; basal line brown, oblique outwards, forming a blotch below the median; outer line just beyond middle, very sinuous, and indented on the submedian fold towards the blotch on first line; a white spot in cell and two at the ends of the discocellular, the bottom one the plainest of the three; two large white oval blotches before hindmargin in the spaces opposite the cell, with black scales on their inner half; two smaller white spots obliquely above them, edged with black, and four blackish spots below them; apical area red-brown; fringe deep red-brown passing into black, except at anal angle, where it is yellow.

Hindwings: wholly yellow, with a basal and wavy postmedian brownish line, most distinct towards inner margin; a submarginal row of black dots; discal spot large, whitish, ringed with fuscous; fringe yellow.

Underside all yellow; forewings with a blackish subapical blotch and the top of an outer line dark. Face, fillet, palpi, and forelegs rather bright red; thorax and abdomen yellow flushed with fulvous.

Expanse of wings : $34 \mathrm{~mm}$.

One of from the Khasias, November 1895.

Related to albonotata Moore. 


\section{Tridrepana trisulcata sp. nov.}

Forewings: whitish, almost wholly suffused with pale sandy ochreous; first line from costa just before middle, whitish, edged with brown by the costa, angled outwards on subcostal and median veins, incurved in cell, and oblique below the median to inner margin before middle; exterior line straight and oblique from inner margin at two-thirds, twice sharply angled beneath costa, whitish, edged inwardly with brown; submarginal oblique and straight till near apex, where it is bidentate; a fine brown marginal line; space on either side of submarginal line rather darker; costal apical area red-brown between the lines.

Hindwings: pale ochreous, with traces of alternate pale and ochreous bands along inner margin only.

Underside pale ochreous, with the lines faint; base of forewings dull brownish. Face and antennae dark brown; thorax and abdomen yellowish ochreous.

Expanse of wings : $28 \mathrm{~mm}$.

Two $\delta$ o from Darjiling.

The pectinations of the antennae are very delicate and rather far apart.

\section{FAMILY THYRIDIDAE.}

\section{Banisia atriclathrata sp. nov.}

Forewings: reddish cinereous, the basal two-fifths and the costal area throughout dull red-brown; the darker portions with obscure dark reticulation, the paler with distinct black spots and strigae; in the middle of the wing is a pale irregular oval space, not reaching either costal or inner margin, with fairly well defined dark edges; fringe dark red-brown, the marginal area before it tending to become darker.

Hindwings: red-brown, with rows of dark spots, and an ill-defined dark central fascia.

Underside paler, with the markings brown, more distinct. Face, head, thorax, and abdomen all red-brown, the thorax somewhat paler; the abdomen with a deeper dorsal stripe and spotted with black on sides and underneath.

Expanse of wings: $30 \mathrm{~mm}$.

One $\delta$ from the Khasias, July 1895.

\section{Banisia elongata sp. nov.}

Forewings: pinkish ochreous, faintly reticulated with darker, the markings pale chestnut; basal half of costa with four or five small square brown blotches with darker edges, from which obscure reticulated lines arise; just beyond the middle a large brown blotch, from which a brown fascia runs vertically to inner margin, with a slight arm projecting externally below costa; before the apex a large pale brown triangular blotch, the apex pointing basewards; its base concisely edged and parallel with the hindmargin, with a fine brown streak from its lower angle to the anal angle, where another similar streak meets it from the subcostal projection of the central fascia ; fringe concolorous, with a fine basal line.

Hindwings: with a dark basal line, followed by a clear paler ochreous space; a central rich brown fascia, with a duller brown shade following it; a small deep brown spot at anal angle. 
Underside paler, with all the markings bright chestnut, the central fascia of the forewings becoming dark brown on the inner margin; hindwings with the basal area, the central fascia, and the hindmargin chestnut, edged with darker, and with dark brown wavy streaks along the inner margin. Palpi and collar dark chestnut; face, thorax, and abdomen greyish ochreous.

Expanse of wings : $32 \mathrm{~mm}$.

One $\delta$ from Cedar Bay, south of Cooktown (A. S. Meek).

The forewings of this species are more elongate than usual, the costa convex near base and before apex.

\section{Banisia mollis sp. nov.}

Forewings: pale ochreous, the reticulations and markings pale brownish; a narrow fascia at one-third, broadened and angulated on the median; a second before the middle, oblique to the median, then vertical and represented only by an elongated $x$-shaped mark; third beyond middle, broadening outwards to the anal angle, its outer edge curved, and joined above the median to the second fascia; fourth forked at costa and ending at middle of hindmargin; apical area pale brownish; all the pale spaces traversed by wavy slightly interlacing pale brown lines; fringe pale.

Hindwings: without fasciae, but with numerous transverse lines on basal half, and two prominent curved brown lines, one from centre of costa to anal angle, the other from before apex to middle of hindmargin.

Underside precisely the same; the cell of the forewings clothed with pale flossy hairs. Head, thorax, and abdomen ochreous tinged with brownish; the abdomen darker brown.

Expanse of wings : $58 \mathrm{~mm}$.

One $\delta$ from Sikkim, July 1889 (Pilcher leg.).

The costal region of forewings, both above and below, is paler ochreous than the remainder of the wing.

\section{Banisia multifenestrata sp. nov.}

Forewings: greyish fuscous, with darker fuscous reticulations and fasciae; a short curved fascia at one-fifth; an inwardly oblique fascia before middle, with concise outer and diffuse inner edge; beyond the middle a fascia which broadens out towards the centre and below the median becomes bifid, the inner branch reaching inner margin at two-thirds, the outer just before anal angle; apical and marginal area with some ill-defined clouds, containing dark black-spotted reticulated streaks; between veins 2 and 4, on each side of the inner fork of the outer fascia, are hyaline spots traversed by vein 3 .

Hindwings: with an obseure basal fascia, a distinct central band, and the whole marginal third, dark greyish fuscous; the space on either side of central fascia more or less hyaline, intersected by the veins and reticulated by transverse strigulae; fringe of both wings concolorous; the edges of the fasciae, especially in the hindwings, are in places marked by black scaling.

Underside paler, with the fasciae brown and more distinct, especially the black scaling at their edges; hindwings with a square blackish blotch at end of cell. Head, thorax, and abdomen all greyish fuscous.

Expanse of wings : $34 \mathrm{~mm}$. 
Two $\delta \delta$ from Humboldt Bay, New Guinea, September and October 1892, taken by Doherty.

One of these examples, not in so good a condition as the other, is much more ochreous in tone; this may be owing to the colour fading, but it appears natural.

\section{Camptochilus sinuosa sp. nov.}

Forewings: yellow; the basal area marked with an aggregation of bright ferruginous wavy lines, the ferruginous area extending from one-fourth of costa to inner margin near anal angle; a ferruginous costal triangle with paler centre at two-thirds ; fringe yellow.

Hindwings: the same, the basal half deeper ferruginous, dappled with paler. In both wings towards the hindmargin the yellow ground-colour is slightly flushed with orange.

Underside like upper. Head, thorax, abdomen, and legs ferruginous.

Expanse of wings: $32 \mathrm{~mm}$.

One $\&$ from Mao, North Manipur (W. Doherty).

The costa of forewings is strongly convex at base and apex, and as strongly concave between; the hindmargin long and strongly curved.

\section{0xycophina gen. nov.}

9. Like Banisia Wlk., but distinguished by the shape of the cell of forewings; the lower angle of cell is at one-half, the upper angle at two-thirds; the discocellular sinuous and oblique outwards, with a strong bent fold from its middle running through cell to base; the lower radial from below this fold, upper radial from a little below the upper angle; first median at two-thirds, second and third close together from the lower end of cell; all the veins free. Antennae shortly and stoutly pectinate. Hind tibiae flattened, hairy, with stout spines. Palpi porrect; forehead protuberant; basal joint of antennae thickened.

Type: Oxycophina subfenestrata sp. nov.

\section{Oxycophina subfenestrata sp. nov.}

Forewings: greyish ochreous, almost entirely suffused with reddish brown and reticulated finely with darker; costa with five red-brown spots, first close to base, second at one-sixth, third at one-third, fourth just beyond middle, fifth at twothirds; from each of the first three of these spots paler reddish fasciae proceed across the wing, the margins of which are undefined; from the fourth a broad darker red-brown fascia, with irregularly dentate brown edges and strongly angulated opposite the cell, goes to the inner margin beyond middle; the spaces on each side of this fascia are paler; marginal area reddish, traversed by several darker, partially connected, lines; fringe whitish, with a broad brown line near its base.

Hindwings: crossed by numerous interlacing dark lines, forming alternately broader and narrower fasciae, of which that in the middle is the darkest and has in the sinuses on its edges some hyaline patches; fringe as in forewings.

Underside the same; the costa of forewings pale, with dark brown spots; the costa of hindwings darker red-brown. Face and palpi bright chestnut; head, thorax, and abdomen paler red-brown varied with darker.

Expanse of wings: $65 \mathrm{~mm}$.

One of from Kinnigunang, New Britain (C. Ribbe). 


\section{Pharambara bullifera sp. nov.}

Forewings: white, suffused and reticulated with rufous ochreous and fuscous; costa minutely dotted with dark and with five pale rufous tooth-shaped marks; four oblique series of conjoined bubble-shaped white spots, in the second and third arranged in pairs on either side of a rufous reticulation; the first curved and consisting of three or four single spots at one-fourth, starting from the first tooth; second curved from between second and third tooth, and stopping at the submedian fold; the third from apex to inner margin; the fourth along hindmargin above anal angle; the intervals between these series rufous, reticulated and suffused with fuscous; a darker shade along submedian vein and beyond end of cell ; fringe coppery rufous.

Hindwings: with three similar series of spots; fringe as in forewings.

Underside with the markings the same, but the dark markings rich brown, the paler ones yellower; lines of shining black and yellow seales below the subcostal. Palpi, face, antennae, and collar dark rufous; thorax and abdomen rufous varied with grey, the latter with a pale ring across second and third segments corresponding with first pale band of hindwings. Palpi porrect, twice as long as head.

Expanse of wings : $26 \mathrm{~mm}$.

Five examples from the Khasias, September 1895 .

Evidently related to glaphyralis Hmpsn., but smaller; the apex of forewing distinctly produced, and the hindmargin beneath it incurved, and again outcurved above anal angle.

\section{Pharambara quadrovata sp. nov.}

Forewings: shining greyish flesh-colour, with scattered short fuscous transverse striae between the veins; the costa broadly paler; a round black spot before apex; fringe concolorous.

Hindwings: with the reticulations in the centre of the wing darker and more prominent; two pairs of white hyaline oval spots; the first beyond the discocellular ; the second between the origin of vein 2 and the inner margin.

Underside paler, more whitish, the mottlings blacker and coarser; a broad ferruginous subcostal streak, marked with a longitudinal row of black spots above, and with metallic scales along the veins; traces of a brownish submarginal and marginal fascia. Head, thorax, and abdomen concolorous with wings.

Expanse of wings : $45 \mathrm{~mm}$.

One $q$ from Oinainisa, 'Timor, November 1891 (W. Doherty).

\section{FaMILY URANIIDAE.}

\section{Stesichora apicipuncta sp. nov.}

Like S. quadripunctata Warr., but the dots at base of costa very small; the blotch at apex much larger, more greyish black, and extending to and along the hindmargin. Hindwings entirely white. Underside of both wings white, but the apex of forewings with a smoky black triangular mark.

Expanse of wings : $28-34 \mathrm{~mm}$.

Four $q q$ from Humboldt Bay, New Guinea, September and October 1892, collected by Doherty. 
ab. bipunctata ab. nov.

A single $q$ from Biak, Geelvink Bay, New Guinea, collected also by Doherty, agrees with apicipuncta in most respects; but the apical blotch of forewings is more restricted, and has a minute dark dot below it, while the anal angle is marked by a distinet dark spot.

\section{FAMILY EPIPLEVIDAE.}

Chaetoceras gen. nov.

Forewings: with costa sinuous, convex near base and apex, concave between ; apex bluntly subfalcate; hindmargin excised from apex to vein 4 , where there is a bluntly bidentate projection at veins 4 and 3 ; thence again slightly excised to anal angle, which is square.

Hindwings: elongate, the apex rounded; hindmargin rounded below apex and straight to anal angle, which is slightly produced.

Palpi very short, not reaching front of face; antennae of $\delta$ strongly pectinated; legs short and stout; hind tibiae swollen, with four long and stout spurs.

Neuration: forewings, cell not half as long as wing; discocellular vertical; first median at three-fourths, second and third from lower end of cell; lower radial from top end of cell, whence also the stalk of 6 and 7 ; the stalk of $8,9,10$, and vein 11 , both from near base. Hindwings with two subcostals and last two medians from ends of cell.

Type: Chatoceras simplex sp. nov.

\section{Chaetoceras simplex sp. nov.}

Forewings: lilac-grey, dusted slightly with vinous red; the lines vinous red; first at one-third, oblique and slightly curved, touching the blackish cell-spot; second at two-thirds, slightly curved and partially interrupted; costa marked with vinous red, and beyond the outer line with three or four ochreous spots; some reddish scales above anal angle; a ferruginous marginal line; fringe rufous, with dark dots at end of veins below middle, altogether dark along the excision.

Hindwings: with red antemedian and postmedian lines and red-edged ocelloid cell-spot; marginal area thickly irrorated with red.

Underside of forewings dull grey; of hindwings whitish ochreous, with a dull fuscous cloud at anal angle. Face dark brown; vertex very pale grey; antennae, thorax, and abdomen pale grey tinged with red.

Expanse of wings : $22 \mathrm{~mm}$.

One $\delta$ from Amboina, February 1892 (W. Doherty).

\section{Chaetopyga gen. nov.}

Forewings: with costa gradually curved; apex depressed; hindmargin toothed at veins $4,6,7$, slightly excised between, and oblique to anal angle, which is strongly marked; inner margin strongly sinuate, lobed in basal half, and excised before anal angle. 
Hindwings: with costa sinuous, excised in middle, fringed with hair on both sides of the excision; hindmargin toothed at $4,6,7$, the tooth at vein 7 acute; inner margin restricted, with a fold containing a tuft of hair.

Forewings beneath with a large bed of flat scales on inner margin at base. Palpi long, porrect, third joint as long as second; tongue present; antennae simple, lamellate; hind femora and tibiae with thick tufts of hair, the tibiae with four spurs; anal segment of abdomen with enormously developed tufts of hair, the penultimate segment beneath also with thick curled tufts.

Neuration: as in Epiplema.

Type: Chaetopyga horrida sp. nov.

\section{Chaetopyga horrida sp. nov.}

Forewings: fawn-colour, dotted with fuscous; traces of a wavy darker line near base; a darker brown central fascia, broad on costa and inner margin, constricted towards the middle, its edges dark brown; a slightly darker diffuse submarginal shade, and a narrow marginal band from apex to tooth at vein 4 .

Hindwings: tinged with ferruginous; a ferruginous postmedian line, sinuous from costa to vein 4 , where it is acutely angled and joined by a dark ferruginous streak from the base.

Underside, especially of hindwings, paler, without markings, but with coarse fuscous atoms. Face and palpi dark brown; head, thorax, and abdomen fawn-colour. Tufts of anal segment pale shining ochreous; of penultimate segment dark fuscous; those of the legs rufous.

Expanse of wings: $36 \mathrm{~mm}$.

One $\delta$ from Port Mackay, Queensland.

The only example is unfortunately much wasted, and the fringes are gone.

\section{Dirades hepaticata sp. nov.}

Forewings: dark purplish grey; the two lines very slender, ochreous; first at one-third, forming a right angle on the median, with a blackish shade on its outside ; second line at two-thirds, straight, inwardly edged with dark; a dark marginal patch opposite the cell; marginal line thick, blackish; fringe paler.

Hindwings: with both lines bent in middle, the first sharply angled, the second bluntly produced; a ferruginous tint before the teeth and a lustrous pearly marginal line.

Underside duller, without markings. Head, thorax, and abdomen all concolorous.

Expanse of wings: $15 \mathrm{~mm}$.

Three $q$ from the Khasias.

\section{Dirades latibrunnea sp. nov.}

Forewings : brownish fuscous, dusted with dark fuscous; first line at one-third, strongly but bluntly angled in midwing; second line from costa at three-fourths to just before anal angle, irregularly waved; the first line edged outwardly, the second inwardly, with dark red-brown, the space between them below vein 3 filled up with dark brown; outer line followed by linear series of blackish striae, which expand into a blackish apical blotch; a row of black white-tipped dots from before apex to below middle of hindmargin; fringe concolorous, with a fine dark basal line. 
Hindwings: with a wavy black mark on inner margin at one-third; a dark brown postmedian line, bluntly angled on vein 4, edged with whitish and followed on inner-marginal half by a patch of whitish scales; some indistinct submarginal black dots edged with white.

Underside of forewings dark brownish grey, with the margin blackish; hindwings paler. Palpi and face black ; fillet and base of antennae white; thorax and abdomen brownish grey.

Expanse of wings : $26 \mathrm{~mm}$.

One $\&$ from Lifu.

The hindmargin of forewings is vertical to vein 6 , thence curved to anal angle; inner margin strongly sinuous. Hindwings strongly toothed at veins 4 and 7 , with a smaller tooth at vein 6 .

\section{Dirades seminigra sp. nov.}

Forewings: grey-brown with a rufous tinge, with numerous fine and close transverse darker striae; first line not expressed, only indicated by the curved margin of the slightly darker basal area; second line rufous, edged outwardly with paler and then with grey, from costa at three-fourths, running straight outwards to third median, where it is bluntly angled, then inwards to inner margin at two-thirds, where it is followed by a dark brown-black triangle with curved edges; submarginal line pale, rufous-tinged, from just before apex to anal angle, having on its outer edge black spots on the veins; fringe concolorous.

Hindwings: brown-black; the basal half varied with rufous grey scales, and with a broadish streak of the same colour from base along middle of wing; an antemedian curved row of three or four black-brown blotches; an angulated rufous grey postmedian line, the inner edge of which on the marginal half is black-brown; a fine pale submarginal line curving with the hindmargin; fringe black-brown.

Underside cinereous, more rufous in forewings. Face and palpi black-brown; fillet white; thorax rufous grey; abdomen black-brown, the first segment with a velvety black ring.

Expanse of wings: $28 \mathrm{~mm}$.

One $q$ from Cedar Bay, south of Cooktown, Queensland (A. S. Meek).

\section{Dysrhombia gen. nov.}

Forewings: with costa strongly curved; apex sharp; hindmargin with four excisions and prominent teeth at ends of veins 2,3 , and 6 ; inner margin slightly sinuate.

Hindwings: elongate, running out to a prominent tooth at vein 4 ; the hindmargin oblique and straight from the tooth to apical and anal angle; distance from base of wing to tooth greater than from base of forewing to its apex.

Antennae of $\delta$ thick, short, and lamellate; palpi porrect, short; hind tibiae swollen, with four spurs ; costa of hindwings fringed with hair except for a short space just beyond middle.

Neuration: forewings, cell one-third as long as wing; first median at seveneighths, second just before angle of cell, third from angle; lower radial from upper angle; upper radial and last subeostal stalked from upper angle; first and second free; third and fourth stalked. Hindwings with the two subcostals from upper angle, the last two medians on a short stalk.

Type: Dysrhombia longipennis sp. nov. 


\section{Dysrhombia longipennis sp. nov.}

Forewings: purplish fuscous; costa streaked with dark fuscous and paler; the lines indistinct and diffuse, blackish mixed with ferruginous seales; first at one-third, angled in midwing; second from middle of costa to middle of inner margin, outeurved in middle; submarginal line irregularly wavy ; fringe concolorous.

Hindwings: with the basal area diffusedly purplish; exterior line from costa at three-fourths, ferruginous edged with paler, running parallel to hindmargin and angled like it in the middle; its inner arm marked with a bloteh of dark purplish and ferruginous scales; veins towards hindmargin pale; hindmargin on each side of tail with a dark streak intersected by the reins.

Head, thorax, and abdomen concolorous with wings; antennae ochreous. Underside dull cinereous, paler towards the margins.

Expanse of wings : $20 \mathrm{~mm}$.

One $\delta$ from Cedar Bay, south of Cooktown, Queensland (A. S. Meek).

\section{Epiplema ambusta sp. nov.}

Forewings: reddish ochreous, more or less suffused with grey-brown or purplish brown, and slightly irrorated with darker; costa dotted with dark fuscous; first line at one-third, dull ferruginous, angled in cell and on submedian fold, the basal area within it clouded with grey-brown; outer line from costa about middle, dark ferruginous, obliquely bent outwards to middle of wing, then, much finer, inwards to inner margin at two-thirds, where it is followed by a dark ferruginous mark; the line is succeeded by a broad greyish purple fascia which leaves the margin of the ground-colour; a dark ferruginous curved submarginal line from just before apex to below middle, beyond which the extreme margin is again greyish purple; marginal line dark brown; fringe concolorous, mottled with darker.

Hindwings: wholly suffused with dark purplish grey, mixed in the middle with ferruginous; a twice-angulated basal line; a triangular pure white discal spot; outer line dark ferruginous, wavy, obtusely bent in middle, and edged externally with ochreous; a ferruginous submarginal line from upper tooth to anal angle, edged with yellowish, and with a yellowish streak into the lower tooth; fringe dark.

Underside purplish cinereous, darker in forewings; hindwings with a dark curved postmedian line. Head and palpi black; thorax and abdomen cinereous.

Expanse of wings : $18 \mathrm{~mm}$.

One $\delta$ from Banda, August 1892 (W. Doherty).

Forewings bluntly rounded, with a slight sinus opposite the cell; hindwings toothed at veins 4 and 7 , crenulate between 4 and 6 , and 6 and 7 .

\section{Epiplema clathrata sp. nov.}

Forewings: pale greyish fawn-colour, speckled with darker; the two lines pale, angulated in the middle of wing, the inner line followed and the outer preceded by brown blotches between the paler veins; marginal line blackish, preceded by two subapical black dots, and a fine, slightly waved, black mark before the excision; fringe pale, darker at apex, elbow, and anal angle.

Hindwings: the same, but the ground-colour smoother, not varied with 
darker; the inner line acutely angled, and joined by a brown central line from base; some lustrous scales along hindmargin.

Underside pale grey, unmarked. Face and palpi dark brown; thorax and abdomen grey.

Expanse of wings : $20 \mathrm{~mm}$.

One $\delta$ from the Khasia Hills.

\section{Epiplema curvilinea sp. nov.}

Forewings: reddish grey, with numerous reddish and fuscous striae; costa dotted with dark brown; first line reddish, indistinct, at one-third, eurved ; second from before two-thirds, sinuous, brown-black, faint between median and submedian, and forming a blotch at inner margin; a fine curved brown line from below apex to above anal angle, the marginal space included rufous; fringe concolorous.

Hindwings: with acutely angled basal line, from the angle of which a dark brown line runs along the middle of the wing touching a broad brown discal blotch; outer line bluntly angled and sinuous, dark brown edged with pale; a sinuous dark brown line from upper tooth to below lower tooth, with a white dash through it at the lower tooth, and a white dash before it between the teeth.

Underside reddish grey, freckled with darker, the outer line distinct. Face and palpi black; head, thorax, and abdomen concolorous with wings.

Expanse of wings: $18 \mathrm{~mm}$.

One $\delta$ from Amboina, August 1892 (W. Doherty).

32. Epiplema fulvata Warr., Nov. ZooL. III. p. 307.

The type from which the description above referred to was made is a $\delta$. The $\uparrow$, which I have now seen, differs slightly, as follows:-

Expanse of wings: $19 \mathrm{~mm}$., against $16 \mathrm{~mm}$. in the $\delta$. Forewings with two distinct black subapical spots. Hindwings with an obseure dark wavy submarginal line from apex to lower tooth, and with blackish scaling between the dark postmedian line and hindmargin. All else as in the $\delta$.

\section{Epiplema fuscifrons sp. nov.}

Like E. bicaudata Noore, but rather larger; the marginal area beyond outer line suffused as in that species with greyish purple, but the suffusion always leaves an apical costal blotch and another from middle to anal angle white. In the hindwings the ferruginous outer fascia is followed by another ferruginous shade, not, as in bicauduta, by a fuscous line. Face and palpi wholly dark fuscous; in bicaudata the face is white both above and below, with a dark central bar.

Two $q$ of from Sikkim.

Hitherto confounded with bicaudata Moore; but an examination of the type now in the British Museum Collection, proves the two species distinct.

\section{Epiplema nana sp. nov.}

Forewings: whitish; costa strongly spotted with dark fuscous; basal area clouded with grey and fuscous; a central purplish fascia, its inner edge strongly inangulated, the outer waved and followed first by a white, then by a dark grey line; 
apex narrowly fuscous; a large fuscous and ochreous spot on middle of hindmargin, traversed by a line of four or five black spots ; fringe dark.

Hindwings: with basal two-thirds mottled with fuscous and purple, and bounded by a curved shade, followed by a straggling fuscous cloud running to hindmargin below lower tooth; a row of three or four blackish spots from costa before apex; a fuscous dark-edged shade along hindmargin from apex to below lower tooth, where it is cut by a whitish dash.

Underside whitish, in the forewings mottled with fuscous. Head wanting; thorax and abdomen dark grey; metathorax with a white bloteh.

Expanse of wings: $11 \mathrm{~mm}$.

One $\delta$ from the Tenimber Islands, July 1892 (W. Doherty).

Akin to E. quadristrigata Wlk. and lituralis Warr., but not half the size.

\section{Epiplema oculifera sp. nov.}

Forewings: ochreous, tinged with rufous grey; first line brown, at one-third, indistinctly marked; second line at two-thirds, obliquely curved and bent outwards to midwing near hindmargin, where it is angled, then oblique inwards and obsolescent to a brown patch on inner margin at three-fourths; a straight brown line from just before apex to below middle of hindmargin; fringe concolorous.

Hindwings: with a reddish brown-edged discal ocellus; outer line pale, with dark edges, the inner edge broadest, running out into a broad prominence before second tooth; a curved brown line from tooth to tooth, and a brown bloteh with a white dash above it below lower tooth; fringe greyish ochreous, with paler base.

Underside dull ochreous; a dark spot before lower tooth of hindwings. Face and palpi brown-black; thorax and abdomen ochreous.

Expanse of wings : $22 \mathrm{~mm}$.

Three of from Dili, Timor, May 1892 (W. Doherty).

\section{Epiplema perpolita sp. nov.}

Very close to $E$. lilacina Moore, from which it differs by the almost entire absence of darker striae and irrorations, which gives the insect a smoother appearance; outer line of forewings more strongly denticulate opposite the cell, the lower arm forming a single curve to inner' margin, where it ends in a thickened line, not preceded, as in lilacina, by a fuscous blotch. Hindwings with the fuscous mottlings of the inner-marginal half obsolete; the dark brown blotch on the inner edge of the postmedian line towards inner margin reduced to a streak.

Two $\delta$ f from Banda, August 1892 (W. Doherty).

The antennae are, as in lilacina, uniserrate, the teeth close and curved.

\section{Epiplema rufimargo sp. nov.}

Forewings: white; costa spotted with rufous grey, and sometimes the basal twothirds; first line marked by three dark spots across wing; second line shaped as in bicaudata Moore, but rufous grey with hardly darker edges; the whole of the marginal area filled up with rufous, except a small white spot beyond the second line on costa and inner margin; some blackish spots towards apex and a blackish cloud at anal angle; fringe wholly rufous.

Hindwings : with rufous curved antemedian line; angulated rufous postmedian 
band with hardly darker edges, followed by a fuscous line which is thickened towards hindmargin; marginal area rufous; fringe rufous, with a paler line along base, most evident between the teeth; a small black spot before lower tooth, sometimes also visible on forewings.

Underside like that of bicauduta Moore, but the forewings not so dark and the hindwings more discoloured. Palpi and face dull white below, fuscous above; vertex rufous; thorax white; abdomen white towards base, tinged with grey and rufous behind.

Both sexes from Sikkim, April and May (Pilcher leg.).

\section{Epiplema unangulata sp. nov.}

Forewings: brownish grey, mottled with darker; the costa with dark strigulations; first line nearly vertical, from costa just before middle to middle of inner margin, ferruginous; second line at two-thirds, angled outwards in midwing, concave on each side of the angle; a submarginal row of fine black dots from before apex to below middle; fringe dark, with a paler base.

Hindwings: with a postmedian curved and wavy ferruginous line; a fine interrupted black line before hindmargin ; fringe concolorous; a small tooth at end of vein 3 , above which the margin is irregularly excised.

Underside pale grey, irrorated with fuscous. Face and palpi brown; vertex and antennae whitish; thorax and abdomen concolorous with wings.

Expanse of wings : $24 \mathrm{~mm}$.

One $q$ from Batchian, March 1892 (W. Doherty).

\section{Eversmannia diversipennis sp. nov.}

8. Forewings: grey, dappled and irrorated with darker; lines very obscure; the first forming a double dark mark on the cell, and another slight mark below it; the outer marked by a dark brownish triangle on costa at two-thirds and a blotch opposite the cell; fringe grey, mottled with darker.

Hindwings: tinged with rufous, whitish towards inner margin, with a few blotches; faint traces of a basal and postmedian line and ocelloid cell-spot.

†. Darker grey, especially in hindwings, and more reticulated.

Underside uniform grey-brown, somewhat paler in the $\delta$. Face and palpi black; fillet and antennae whitish; thorax and abdomen concolorous with wings.

Expanse of wings : $24 \mathrm{~mm}$.

Three $q+$, one $\delta$, from Amboina, February 1892 (W. Doherty).

The costa of forewings is sinuous, especially in the $q$; hindmargin excised from the bluntly rounded apex to vein 4 , and between veins 4 and 3 , then oblique to anal angle. The hindwings of the $\delta$ are narrow, with the hindmargin rounded throughout; in the $q$ they are broad; the hindmargin vertical from apex to vein $\bar{\tau}$, then straight and oblique to vein 3 , between which and the anal angle there is a deep excision, much as in Thymistada tripunctata Wlk.

\section{Gathynia pernigrata sp. nov.}

Forewings: with the costal half of wing whitish, the inner-marginal half rufous, the whole densely covered with fine dark atoms and striae; the costa grey, with white spots towards base and apex; a broad oblique purplish central fascia, darker on costa 
and inner margin, speckled with white in the middle, its edges irregularly brownblack; basal area with a diffused blackish blotch; marginal area with a diffuse oblique cloudy fascia, and some black dashes and teeth from costa before apex to middle of hindmargin.

Hindwings: wholly suffused with dark purplish fuscous, with a white blotch at end of cell, followed by a dark antemedian line; a dark curved postmedian line and a strongly dentate submarginal line; fringes dark.

Underside dark cinereous, with darker striae; inner half of forewings rufoustinged. Face black; collar rufous grey; thorax and abdomen purplish mixed with rufous ; inner margin of hindwings and tuft pale ochreous.

The specimen above described appears to be a pale form; in another example the white markings are greatly reduced, the central fascia being dark throughout, and the whole forewing suffused with dark; the hindwings without any white blotch at end of cell.

Expanse of wings : $28-30 \mathrm{~mm}$.

Two of o from the Khasias.

\section{Gathynia vinosa sp. nov.}

Forewings: vinous red-brown; the costa darker, fuscous-tinged; traces of a dark line near base; second line brown, from costa at two-thirds, oblique outwards to middle, then sharply incurved to the top of an ill-defined brown triangular blotch on inner margin beyond middle; the line and blotch edged with ferruginous; a fine straight blackish line from just before apex to anal angle; fringe concolorous with wings.

Hindwings: with a curved and slightly elbowed brown paler-edged line at twothirds; some black spots along hindmargin.

Underside dull reddish ochreous. Face and palpi brown; thorax and abdomen brownish grey, the latter becoming paler at end, like the pale inner margin of hindwings.

Expanse of wings: $18 \mathrm{~mm}$.

Three of for from Dili, Timor, May 1892 (W. Doherty).

\section{Lobogethes gen. nov.}

Forewings: with costa straight for three-fourths; hindmargin oblique, hardly eurved ; inner margin straight.

Hindwings: with costa sinuous only, not excised, fringed with hair towards base and apex; hindmargin excised below apex; in the $q$ with a blunt hook at end of third median, and thence rounded to inner margin; in the $\delta$ with a rounded bulge from middle of cell to second median, beyond which there is an incision and the inner-marginal area ends in a broad lobe. At the base of the hindwing below the median vein is an elongated oval hyaline space, the upperside of which is clothed with a tuft of spatulate scales.

Antennae thick, lamellate; palpi inclined upwards, as long as face; hind tibiae of $\delta$ thickened, with four spurs.

Neuration: forewing, first median from near base, second a little before end of cell ; discocellular angulated and apparently all but obsolete below ; the lower radial from the angulation; 6 and 7 on a long stalk; 8 and 9 stalked. In the hindwings 
the first median rises from the base, and the hyaline fovea lies between it and the median nervure.

The insect rests with the wings folded and rolled as in Gathynia Wlk.

Type: Lobogethes interrupta sp. nov.

\section{Lobogethes interrupta sp. nov.}

Forewings: dark grey, speckled with fuscous, this colour being confined to the costa, the inner margin, and the space immediately below the median; the intervening areas dull ochreous, broad on hindmargin and narrowing to a point near base; a dark grey blotch on costa at three-fourths, preceded by a smaller one on the subcostal and another at one-third; fringe grey, with dark basal line.

Hindwings: with the dark areas narrower and the pale ones in proportion wider; traces of an angulated postmedian line, and a row of iron-grey lunules along the hindmargin from apex to middle. The pale spaces are not so conspicuous in the $\delta \delta$, in which sex the whole of the hindwings above the third median is dark grey.

Underside dull cinereous. Face and palpi dark brown; vertex, thorax, and abdomen pale grey, the latter more or less tinged with dark in the middle.

Expanse of wings: $22-28 \mathrm{~mm}$.

Several of both sexes from Coomooboolaroo, Duaringa, North Queensland (A. S. Meek).

\section{Macrostylodes gen. nov.}

Forewings : with costa rather strongly curved throughout; apex broadly rounded; hindmargin rounded, and slightly indented above anal angle.

Hindwings: with hindmargin rounded, and minutely toothed at veins 4 and 7 .

Palpi short, porrect; antennae of $\delta$ flattened and thickened, uniserrate, the teeth close and curved.

Neuration : forewings, discocellular invisible, apparently absent ; first median at one-sixth of wing; second and third on a long stalk, separating at five-sixths; the two radials and last subcostal stalked, the lower radial leaving beyond middle, the other two separating at five-sixths; veins 8 and 9,10 and 11 , stalked. Hindwings with the two subcostals separating at two-thirds, the last two medians at about onethird; radial absent.

Type: Macrostylodes deformis sp. nov.

\section{Macrostylodes deformis sp. nov.}

Forewings: white, irregularly varied with transverse fuscous striae; costa thickly dotted with fuscous; first line obseure, at one-third; second at two-thirds, sinuous and nearly vertical, preceded on inner margin by denser fuscous strigae and a brown erect streak from middle, above which is a brown spot; marginal area more densely striated, especially above anal angle, and with two blackish subapical spots ; marginal line brown.

Hindwings: with the two lines distinct; the second bent outwards before lower tooth; an indistinct row of dark lunules from tooth to tooth.

Underside whitish, in the forewings wholly suffused with fuscous, in the hind- 
wings with only the apex fuscous. Face and palpi dark brown; thorax and abdomen whitish, mottled with fuscous.

Expanse of wings : $12 \mathrm{~mm}$.

Two $\delta$ o from Humboldt Bay, New Guinea, October 1892 (W. Doherty).

\section{- Paradirades gen. nov.}

Forewings: with costa sinuous, slightly incurved in middle; hindmargin sinuous, strongly incurved below apex, then bulged and oblique at anal angle; inner margin straight.

Hindwings : with costa straight, not excised nor tufted; hindmargin sinuate, as in forewings.

Antennae thick, lamellate; palpi short ; forewings of of with a very large double fovea at base, the lower half inflated, the upper depressed; hindwings with no fold and tuft of hair on inner margin.

Neuration: forewings, lower radial from well below the upper angle of cell; 6 and 7 stalked; 8 and 9 stalked; 10 and 11 stalked; 11 auastomosing with 12 .

Type: Paradirades assimilis sp. nov.

\section{Paradirades assimilis sp. nov.}

Forewings: pale grey, speckled with fuscous; a dark blotch on costa at middle, one on the discocellular, and another at middle of inner margin represent the curved first line; a costal blotch at three-fourths and a smaller one on inner margin before anal angle indicate the second line; before the apex is another small blotch, and one on the hindmargin at middle; fringe dark. blotches.

Hindwings: the same, with an antemedian and postmedian line of interrupted

Underside dull grey. Head, thorax, and abdomen all dull grey.

Expanse of wings: $16 \mathrm{~mm}$.

Three $\delta \delta$ from Cedar Bay, Cooktown, Queensland (type) (A. S. Meek); and one $\delta$ from Humboldt Bay, New Guinea.

The insect bears a superficial lesemblance to Epiplema imorata Moore.

FAMILY GEOMETRIDAE.

SUbFamily OENOCHROMINAE.

Oenochlora gen. nov.

Forewings: elongate; the costa strongly arched from base to apex; apex somewhat produced; hindmargin oblique, eurved at anal angle.

Hindwings: with apex and hindmargin rounded.

Antennae three-fourths of wing, in $\delta$ regularly pectinated throughout. Palpi upcurved in front of face; second joint squamous, just reaching above forehead; third joint small, blunt. Tongue present; frenulum present. Hind tibiae somewhat thickened, with a pencil of hairs and four spurs.

Neuration: forewings, cell quite half the length of wing; discocellular slightly 
inangulated; first median at two-thirds, second just before the end, third from the end of cell; lower radial from centre of discocellular; upper from upper angle; last four subcostals stalked from shortly before the angle of cell, the extremity of the subcostal nervure being bent inwards from the origin of the stalk, as is that of the median nervure from the second median nervule; first subcostal from cell, soon anastomosing with the costal, as does the second also. Hindwings with discocellular straight, the radial rising from its centre; costal running close alongside of subcostal for half the cell; first subcostal nervule and second median each from just before angle of cell.

Type: Oenochlora imperialis sp. nov.

The costal neuration of the hindwing forbids this genus being referred to the subfamily Geometrinae, as the green coloration of the type-species would obviously suggest; while the presence of a radial in the hindwing similarly prevents its admission to the Ennominae. I cannot, however, identify it with any of the genera of the Oenochrominae as given by Mr. Meyrick.

\section{Oenochlora imperialis sp. nov.}

3. Forewings: dark apple-green, the costal region with short transverse purple striae; the lines darker green; first at one-third, curved and wavy; second at three-fourths, parallel to hindmargin, crenulated; cell-spot purple; fringe green.

Hindwings: like forewings, without first line, and with the costal region broadly pale rosy, the inner margin white.

Head, thorax, and abdomen green; tips of palpi rosy; antennae ochreous. Underside dull orange-grey, with a broad purple submarginal fascia, the margin itself becoming whitish green; cell-spots purple.

In the $q$ the cell-spots are absent; the lines hardly visible; and the forewings have a pale yellow oval spot edged with red between the second and third medians; while the abdomen bears a purple blotch in the middle.

Expanse of wings: $40 \mathrm{~mm}$.

One $\delta$, one + , from Cedar Bay, Cooktown, Queensland (A. S. Meek).

\section{Oenochroma decolorata sp. nov.}

Forewings: grey, with fine darker irroration; inner line reddish and only distinct on costa; cell-spot dark grey, indistinct, followed by an obseure oblique central shade; outer line pale ferruginous, edged internally with whitish; fringe purplish.

Hindwings: with an antemedian purplish line, and a median line ferruginous with paler internal edge, as in forewings, the ferruginous tint passing into purplish towards apex, which is itself tinged with purplish.

Underside whiter, the outer line marked by vein-dots; the purple spot on inner margin much smaller than in vinaria Guen, hindwings white along inner margin; the hindmargin broadly tinged with ferruginous. Face, thorax, and abdomen grey, the latter paler.

Three examples from Cedar Bay, Cooktown, Queensland (A. S. Meek).

Besides the difference in coloration, the present species differs from $O$. vinaria Guen. in having the hindmargin of hindwings distinctly eurved and the apex obtuse, whereas in vinaria the margin is straight and the apex produced. 
47. Physetostege miranda rufata subsp. nov.

A $q$ from Cedar Bay, Cooktown, and a $\delta$ from Geraldton, Cairns, differ considerably from the type-form, miranda Warr., from Humboldt Bay. They expand only $28 \mathrm{~mm}$., are much brighter red, and towards the costa of hindwings before the outer line are marked with a black blotch.

\section{Sarcinodes compacta sp. nov.}

Forewings: reddish fawn-colour, quite sparsely dusted with fuscous; a faint reddish spot on costa at one-fourth and a black dot on the median vein indicate the first line; a small reddish cloud at middle of costa; a straight deep chestnut line from costa before apex to inner margin beyond middle, followed on third median by a round red-brown spot; fringe chestnut.

Hindwings: with the dark line central, the base pale, with an obscure line at one-fourth.

Underside with the margins flushed with deeper red, and with indications of a central line; the oblique line marked by dark vein-dots; a white subapical and apical costal blotch. Head, thorax, and abdomen somewhat paler than the wings; tips of palpi and frontal tuft blackish. Antennae of $\delta$ with the uniserrate pectinations long.

Expanse of wings : $52 \mathrm{~mm}$.

One $\delta$ from Amboina, February 1892 (W. Doherty).

Related to S. subfulvida Warr, but smaller, more uniform in tint both above and below; the oblique line entirely dark.

\section{Zeuctophlebia gen. nov.}

Forewings: with costa slightly curved and faintly inbent in middle; apex produced, subacute; hindmargin sinuous.

Hindwings: with rounded hindmargin.

Face smooth; palpi porrect, squamous, the third joint indistinct; antennae of $\delta$ strongly bipectinate to five-sixths; hind tibiae with four spurs.

Neuration : forewings with cell half as long as wing; first median at five-sixths, second before end of cell, third from end; lower radial from middle of discocellular ; upper from upper angle of cell ; last three subcostals stalked ; first and second coincident, anastomosing with costal, the second afterwards anastomosing with the stem of third and fourth. Hindwings with first subeostal rising before end of cell.

Type: Zeuctophlebia rufipalpis sp. nov.

\section{Zeuctophlebia rufipalpis sp. nov.}

Forewings: greyish ochreous, finely dusted with fuscous atoms, more thickly along costal region ; costal edge towards base reddish ; first line at one-third, slightly curved below costa, then straight, with some dark scales externally; second line from costa beyond middle, running straight outwards below costa, then sharply angled and slightly curved to middle of inner margin, pale, with brownish edges, met at the angle by a ferruginous oblique streak from apex; a submarginal row of double black points; a marginal row of black dots; fringe glossy, rufous grey, with paler base; a black cell-dot.

Hindwings: the same, without first line. 
Underside reddish, thickly mottled with blackish; the two outer lines and cellspots blackish. Palpi, face, and forelegs bright red; vertex, thorax, and abdomen pale grey, with dark atoms; collar dark grey.

Expanse of wings : $26 \mathrm{~mm}$.

One $\delta$ from Toowoomba, Queensland.

\section{SUBFAMILY ORTHOSTIXINAE.}

\section{Bociraza latiflava sp. nov.}

Forevings: golden yellow; the costa narrowly black at base, the streak thickening to the middle; a broad black fascia from the middle of costa to anal angle, its inner edge curved, its outer edge nearly straight; apex and hindmargin black, leaving a broad yellow fascia from costa to near hindmargin; fringe black.

Hindwings: yellow, with black marginal fascia from anal angle to apex, where it is wider.

Underside the same. Palpi yellow, externally fuscous; face and vertex yellow, sometimes tinged with grey ; collar fuscous ; thorax and abdomen yellow.

Expanse of wings : $36-42 \mathrm{~mm}$.

Two $\delta \delta$, two $q f$, from Humboldt Bay, New Guinea, October 1892 (W. Doherty).

\section{Celerena triflava sp. nov.}

Forewings: yellow, with the costa black from base to middle, whence a black bar runs at right angles towards anal angle, which it does not quite reach; the costal streak and the cross-bar both diffusely edged internally; hindmargin from anal angle narrowly black, the inner edge waved, and bent above third median to costa at twothirds; the apical black area so formed contains an oblique yellowish blotch ; fringe black.

Hindwings: yellow, with narrow black border with wavy edge.

Underside the same, except that the cross-bar of forewings is much broader than above, angled outwards in the submedian interspace and joined along inner margin with the marginal border. Face, thorax, and abdomen yellow; palpi black; collar fuscous.

Expanse of wings: $64 \mathrm{~mm}$.

One + from Biak, Geelvink Bay, New Guinea, collected by Doherty.

\section{Eumelea degener Warr., ab. umbrata nov.}

In this form the space between the outer line and the row of submarginal spots is wholly clouded with brown in the forewings of the $q$, the spots themselves becoming absorbed; in the hindwings the brown shade does not reach the spots; in one $f$ the yellow ground-colour of the entire wing is suffused with pale brown.

In the $\delta$ the whole of the wings is thickly suffused with brown and covered with fuscous striae, the markings being rendered indistinct; the underside yellower, with dark purple fuscous mottlings and markings.

Three $\delta \delta$, one $q$, from Lifu. 


\section{Eumelea feliciata sangirensis subsp. now.}

Forewings: dull yellow, olive-tinged, covered uniformly with dull rosy striae, which are much finer and longer than in the type-form of feliciata Guen.; the usual three lines very indistinct and narrow, the curved central one in particular being almost linear; fringe and marginal lunules bright rosy.

Hindwings: the same.

Underside brighter yellow, with the lines thicker and rosier. Head, thorax, and abdomen concolorous.

Expanse of wings: $58 \mathrm{~mm}$.

Two of from Sangir (W. Doherty).

\section{Eumelea ludovicata atomata subsp. nov.}

Forewings: blood-red, the yellow area, which is restricted to the cell and space beyond and to the submedian fold, being more or less obliterated by coarse spore-like red blotches; cell-spot and vein-spots marking the course of the submarginal line deeper red; a yellow spot at apex.

Hindwings: the same, but the central line darker and denticulate; fringe of both wings red.

Underside with all the red markings dull brown-red. Face blood-red; vertex red, with yellow scales; thorax and abdomen red.

Expanse of wings : $50 \mathrm{~mm}$.

One $\delta$ from South Java, 1500 feet, 1891 (Fruhstorfer).

\section{Eumelea ludovicata biflavata subsp. nov.}

Forewings: wholly irrorated and suffused with deep orange-red, leaving only two round pale yellow spots before the submarginal shade, one opposite the cell, the other on the submedian fold; these spots on the hindwings almost obliterated by rosy strigulae; apex of both wings narrowly yellow.

Expanse of wings: $52 \mathrm{~mm}$.

One $\delta$ from Nias; one $q$, nine $\delta \delta$, from Pulo Laut, S.E. of Borneo (type), May 1891 (W. Doherty).

Consistently smaller than the typical form of ludovicata Guen.; the $q$ not yellow, but concolorous with $\delta$.

\section{Eumelea ludovicata fumicosta subsp. nov.}

Wings less brightly coloured than in ludovicata Guen., somewhat blurred; the costa and apical region and part of the hindmargin in the forewings darkened with dense fuscous striae; both wings without any trace of lines.

Expanse of wings: $58 \mathrm{~mm}$.

One $\delta$ from the Bismarck Archipelago (locality erroneous?) ; two $q q$ from New Georgia and Alu (type), Solomon Islands, respectively.

\section{Eumelea ludovicata insulata subsp. nov.}

Wings with the yellow ground-colour uniformly irrorated with orange-red, the pale yellow spots beyond cell and on submedian fold not conspicuous; central 
fascia of forewings straight, not curved inwards towards the costa; coloration of the two sexes similar.

Expanse of wings : $58-60 \mathrm{~mm}$.

One $\delta$, two $q+$, from the Loochoo Islands.

58. Eumelea ludovicata rubrifusa subsp. nov.

ठ. Forewings: almost wholly suffused with deep orange-red, much more so than in biflavata Warr., leaving, as in that subspecies, only two yellow spots, which are more conspicuous owing to the deejer red of the rest of the wing; a yellow spot on discocellular, and a few yellow scales before the middle of the hindmargin.

Hindwings: with the two yellow spots still smaller; a yellow spot on the discocellular; apex yellow.

. Orange-yellow, irrorated with darker, with the spots marking the lines dull rosy; three spots marking the antemedian line; a spot on discocellular; an interrupted curved postmedian line and blotched submarginal line most distinct towards costa. Hindwings with the cell-spot large, rosy, and a very large rosy blotch on the middle of costa.

Expanse of wings: $65 \mathrm{~mm}$.

One $\delta$, one $q$, from Kina Balu, North Borneo.

\section{Eumelea praeusta sp. nov.}

ठ. Forewings: bright yellow, with orange striae and suffusion; costa thickly streaked with fuscous purple striae; traces of a curved line at one-fourth, formed by two or three orange tawny blotches; a broad ferruginous orange slightly curved fascia just beyond middle; space between the two thickly covered with orange-red striae along costal half; a large purplish red apical blotch, its edge curved from threefourths of costa to near middle of hindmargin, containing a small yellow spot at apex; some orange-red striae and blotches at anal angle.

Hindwings: with costal region covered with orange-red striae; the second line of forewings continued, but narrower and straighter, across centre from middle of costa to two-thirds of inner margin; apex and anal angle orange-red, the former with a yellow spot at tip.

Underside like upper, but the dark markings all tinged with purple. Face and palpi orange-red; thorax and abdomen yellow.

Expanse of wings : $65 \mathrm{~mm}$.

One $\delta$ from Batchian (type), March 1892, taken by Doherty; and two $\delta \delta$, one $q$, from Ternate.

The $q$ is duller yellow, with dull purple-brown markings instead of the bright orange-red of the $\delta$; the middle fascia is narrower, zigzag, and interrupted in the middle; the apical patch is formed only of some scattered dull purplish scales. But on the underside the difference between the two sexes is not so striking.

\section{Ozola marginata sp. nov.}

Forewings: whitish ochreous, uniformly dusted with blackish ; first line at onefifth, dark brown, distinct only towards costa, below which it is angled and becomes more or less obsolete; a dark cell-spot; marginal third, from costa at two-thirds to 
inner margin before anal angle, purplish brown, leaving the apex and a roundish spot in middle of hindmargin pale; fringe purplish brown, chequered with ochreous over against the hindmarginal blotch.

Hindwings: with dark cell-spot and a broad uninterrupted purplish brown marginal fascia from apex to anal angle; fringe concolorous.

Underside exactly the same. Head, thorax, and abdomen ochreous.

Expanse of wings: $32 \mathrm{~mm}$.

Five $\delta \delta$, two $q+q$, collected by Doherty; four $\delta \delta$ from Yamma; one $\delta$ from Humboldt Bay, New Guinea (type); the two $q$ from Gani, Halmaheira, and Salawatti respectively.

Occurs also in Amboina.

\section{Rambara colorata sp. nov.}

Forewings: bluish white, with all four series of spots ochreous, the dircal spots large and with a fulvous centre.

Hindwings: the same.

Underside pure white.

Expanse of wings: $12 \mathrm{~mm}$.

Several from the Tenimber Islands, June and July 1893 (W. Doherty).

Distinguished not only by its minute size, but by the marginal series of dots being ochreous, like the rest, not black.

\section{SubFamily PSEUDOTERPNINAE.}

\section{Actenochroma discolor sp. nov.}

Forewings: bright ochreous, suffused with pale brown and with dark brown and fulvous markings; a fulvous patch on costa at base ; first line at one-third, strongly waved ; second from two-thirds of costa, much excurved beyond cell, wavy and denticulate to inner margin at middle, where it closely approaches the first line; this outer line is marked with brown-black on costa, opposite the cell, and in the submedian interspace; the inner half of the central fascia included between the first and second lines is dull grey-brown, extending along the costa from line to line; an interrupted oblique red-brown shade starting from a triangular red-brown costal blotch follows the exterior line; submarginal line represented by interrupted redbrown blotehes which run into the margin; fringe ochreous, broadly mottled with dull red-brown.

Hindwings: like forewings, but with the whole basal area to exterior line greyish tawny with darker striae; the lines with dark brown blotches opposite the cell; both wings with obscure brown cell-spot.

Underside of forewings bright yellow as far as outer line, which is bent and dark brown with reddish scales intermixed; cell-spot large, blackish, followed by a white blotch; a broad reddish submarginal band, varied with black and separated from outer line by a white band constricted in middle; marginal area reddish and black, leaving a whitish blotch at apex and middle of hindmargin. Hindwings yellow from base to outer line, which is broadly blackish and straight; no cell-spot; marginal third blackish, with a white spot on hindmargin at middle, and separated from outer 
line by a wedge-shaped white costal mark; inner margin and fringes wholly yellowish white. Head, thorax, and abdomen ochreous mottled with darker.

Expanse of wings: $48 \mathrm{~mm}$.

One $\delta$ from Korrido, Dutch New Guinea, eaptured by Doherty.

\section{Actenochroma ochrea sp. nov.}

Forewings: pale ochreous, with olive-grey and rufous mottling; costa dotted with rufous; the lines starting from rufous costal blotches; first at one-third, slightly wavy and oblique outwards, reddish brown; second beyond two-thirds, slightly excurved and dentate to inner margin before anal angle; discal blotch rufous grey, connected with a rufous subcostal spot above it; the space between the lines washed more or less with rufous, especially towards the edges, a semicircular space on inner margin often remaining pale; a rufous grey blotch beyond cell extending to hindmargin, showing two teeth of the submarginal line, which is else unexpressed; some reddish clouds above anal angle; fringe pale ochreous, marked with rufous opposite the cell and above anal angle.

Hindwings: with the markings often very obscure; the basal area sometimes shaded with darker; a curved dentate postmedian line, the teeth showing red-brown, and sometimes some reddish clouds towards margin beyond cell.

Underside brighter ochreous; the discal spot large, black, tinged with red; the lines both distinct, eurved, red-brown, joined along the submedian interspace by a broad crimson streak; marginal area varied with fuscous and reddish. Hindwings with dark reddish cell-spot and curved outer line, and a cloudy crimson submarginal fascia.

Face, head, thorax, and abdomen all ochreous; face with a narrow crimson bar; palpi externally dark red-brown.

Expanse of wings: $40 \mathrm{~mm}$.

Three $q$ from Port Mackay, Queensland.

\section{Hypochroma subornata sp. nov.}

Forewings: pearly grey, with a pink tinge, and dusted with dark grey atoms; first line at one-fourth, dark grey, slightly curved and minutely denticulated ; second line at two-thirds, curved and minutely denticulated, the teeth on second and third median nervules more prominent; submarginal line pale, wavy, with darker edges; discal spot large, pearly grey, with a darker centre; a row of black marginal spots at the ends of the veins.

Hindwings: the same, but the central space much varied with rufous and black scales; the basal area of both wings with tufts of rough whitish scales.

Palpi and lower three-fourths of face dull rufous; top of face, vertex, and thorax grey; abdomen whitish. Underside of forewings with basal two-thirds in $q$ deep orange, in $\delta$ rosy, with an orange subcostal streak; a small white spot preceding and a larger one following the large black cell-spot; marginal third black, with a row of white spots down the centre, beyond which the black becomes discoloured; hindwings the same, with no cell-spot; the extreme margin whitish.

Expanse of wings: $48 \mathrm{~mm}$.

One $\delta$, one $q$, from Cedar Bay, south of Cooktown, Queensland. 
65. Terpna crassistriga sp. nov.

Forewings: dull olive-green, thickly and coarsely speckled with dark purplish fuscous; the lines of the same colour; a short mark close to base; first line at one-fourth, outwardly oblique and slightly toothed in cell; second at two-thirds, thick and curved to vein 4 , where it is bluntly angled, then lunulate and inwardly oblique to inner margin at three-fourths; marginal area more densely speckled, especially above anal angle; an oblong dark cell-spot; a row of dark spots at ends of veins; fringe olive, with a paler line at base.

Hindwings: densely speckled with fuscous and reddish; a dark cell-spot and denticulate postmedian line; submarginal line indicated by blackish blotches above anal angle and opposite cell.

Underside whitish, with slight striation; cell-spot of forewings large, blackish; of hindwings small; marginal third of both wings blackish, rufous-tinged; in the hindwings with the margin itself paler. Face deep brown; palpi green; vertex and collar pale ochreous; thorax and abdomen cinereous green, with dark specks.

Expanse of wings : $46 \mathrm{~mm}$.

One $q$ from Bunguran, Natuna Islands, October 1894 (Ernest Hose).

\section{SubFamly GEOMETRINAE.}

\section{Acrortha gen. nov.}

Forewings: with costa arched at base, then straight for four-fifths, where it is abruptly elbowed and again runs straight to apex; apex rounded; hindmargin obliquely curved.

Hindwings: with hindmargin produced to a blunt point at third median; apex rounded ; margin sinuate to the point, thence straight to anal angle.

Palpi short, porrect; second joint roughly scaled beneath; third smooth. Tongue present. Antennae of $\delta$ pubescent. Frenulum invisible.

Neuration: forewings, cell one-third of wing; discocellular vertical, the lower two-thirds hardly visible; first median at three-fourths; second and third stalked; lower radial from above centre of discocellular; upper from upper angle of cell ; the five subcostals stalked from the angle; first and second coincident and becoming coincident with the costal, which reaches costa at the elbow. Hindwings with the discocellular oblique; the two subcostals and last two medians stalked.

Type: Acrortha flexicosta sp. nov.

\section{Acrortha flexicosta sp. nov}

Forewings: pale green, the fringe paler; first line whitish, edged outwardly by a deeper green shade, bent below the costa, then slightly oblique inwards; second from the elbow, faintly bent near costa, then parallel to hindmargin to inner margin at three-fourths, edged with darker green internally.

Hindwings: with a curved whitish postmedian line, and dark green cell-spot.

Face, vertex, thorax, and abdomen green; fillet white. Underside pale silvery green,

Expanse of wings: $20 \mathrm{~mm}$.

One $\delta$ from Kandy, Ceylon. 


\section{Agathia disconnecta sp. nov.}

Forewings: apple-green; base dark brown on costal half; costa ochreous, with grey speckles; first line before middle, formed by three disconnected brown spots, one below costal streak, one on inner margin in middle, the third on median vein, angled outwards; second line at three-fourths of costa, formed by two pairs of brown spots lying in an oblique line on veins 7 and 6 , and 4 and 3 ; and two smaller spots lying on veins 2 and 1 , near to hindmargin; brown marginal spots at end of veins, that at the apex being square and prominent, that at the angle on vein 4 conspicuous; fringe yellowish white, with a brown spot at vein 4 , and discoloured at anal angle.

Hindwings: with the outer line as in forewings, only that each pair of spots is coalescent and forms a blotch with its inner edge straight; the last spot, on the internal vein, is much nearer base of wing; marginal tooth wholly filled up with dark chocolate-brown, with a pale whitish band across the base; marginal spots at veins 6 and 7 conspicuous; fringe yellowish white, brown round the tooth and at vein 6 .

Underside pale green, with the markings vinous and tending to become connected into fasciae. Face and palpi pale ochreous below, brown above; vertex, thorax, and abdomen green; the latter with patches of greyish red with darker red centres on each segment.

Expanse of wings : $36 \mathrm{~mm}$.

Two $\delta \delta$, three $q q$, from Geraldton, near Cairns, North Queensland (A. S. Neek), and a pair marked North Queensland only. The red-brown markings become in the + more ferruginous, as in all the allied species; in both sexes the spots are more or less edged with yellow; in some examples, especially in the $q q$, the spots of the central fascia tend to become united above.

\section{Agathia rubrilineata sp. nov.}

Forewings: green, with an olive tinge; base narrowly red-brown on lower two-thirds; costa grey, with darker specks, edged beneath by a fine red line, the grey streak starting fine at base and broadening to the central fascia; this runs nearly straight from the costal edge at one-third to the inner margin at two-thirds, whitish with irregular red edges, which are slightly broadened and uneven at the veins; marginal one-fourth reddish grey, edged inwardly by a broad, slightly irregular, inwardly white-edged, red-brown line, which forms two small teeth outwardly on veins 4 and 5; in this area is a subapical subquadrate green patch, the inner edge rounded, the outer straight and parallel to hindmargin, which it nearly touches, and having above and below it a round whitish spot adjacent; area above anal angle yellowish; marginal line thick, brown; fringe ochreous, with a darker central line.

Hindwings: green, the inner margin narrowly red; marginal area as in forewings, containing an irregularly oval green patch from veins 4 to 7 ; the red-brown line that edges it having an additional tooth on vein 3 ; a red-brown semicircular spot on lower part of the marginal tooth edged with ochreous; fringe as in forewings, but reddish brown at the tooth.

Underside pale green, washed towards base with dull rufous; marginal fasciae dull red-brown; middle fascia of forewing brighter red. Palpi and face below ochreous; 
palpi above, upper part of face, fillet, and antennae brown; crown of head, shoulders, and base of patagia green; rest of patagia, thorax, and abdomen ochreous mixed with reddish scales; metathorax green; basal segment of abdomen with a pair of dark spots.

Expanse of wings : $40 \mathrm{~mm}$.

One $\delta$ from Mt. Mulu, North Borneo, 1000—4000 feet (Charles Hose).

\section{Anoplosceles gen. nov.}

Forewings: with costa arched throughout; apex produced; hindmargin obliquely curved.

Hindwings: kite-shaped; the hindmargin tailed in middle, curved slightly above the tail, straight below to anal angle, which is very strongly developed.

Antennae of $\delta$ lamellate, thick, subdentate; palpi with second joint stout, squamous; third almost as long, narrower, and blunt, with appressed scales; middle tibiae with only a pair of spurs; hind tibiae swollen, with a groove and pencil of hairs, but with no spurs. Frenulum present.

Neuration: forewings, cell one-third as long as wing; first median at twothirds; second and third short-stalked; lower radial from above the centre of discocellular; upper from top angle; last four subcostals stalked from upper angle; first free, anastomosing with the costal. Hindwings with the two subcostals on a short stem; the last two medians on a very long one.

Type: Anoplosceles nigivipunctata sp. nov.

Shape of wings as in Thalerwra Warr.; distinguished by the lamellate antennae and the spurless hind tibiae.

\section{Anoplosceles nigripunctata sp. nov.}

Forewings: pale green, the costa dotted with fuscous towards the apex; the lines dark green, strongly denticulate; the first at one-third, indistinct; the second at two-thirds, parallel to hindmargin; marginal line red-brown, broadly interrupted by ochreous spots at ends of veins; fringe ochreous at base, with grey tips; cell-spot distinct, black.

Hindwings: like forewings; no first line; second line forming a strong projection in middle opposite the tooth; the dark green line on both wings ends on inner margin as a dark red-brown spot.

Thorax and abdomen green; face, palpi, and antennae red-brown; vertex white. Underside whitish green, with the outer line of forewings dark.

Expanse of wings : $30 \mathrm{~mm}$.

One of from West Java.

\section{Chrysochloroma electrica sp. nov.}

Forewings: very deep emerald-green, in certain lights shading into blue, and towards base to yellow ; lines very obscure, slightly paler and faintly lustrous; first curved, at one-fifth ; second at three-fourths, parallel to hindmargin ; a small cell-spot and the fringe deep violet-brown.

Hindwings: like forewings, with the cell-spot much larger; the outer line alone present, bent in middle. 
Head, thorax, and abdomen paler, more yellowish green ; face bright ferruginous ; palpi above brown-red, whitish below. Underside uniform electric-blue; the fringes dark brown.

Expanse of wings: $42 \mathrm{~mm}$.

Two $\delta$ from Roon Island, New Guinea.

The absence of one of the median spurs of the hind tibiae of the $\delta$, recorded as one of the characteristics of the genus, Nor. ZooL. III. p. 288, does not appear to be constant. The present species has all four spurs.

\section{Chrysochloroma subalbida sp. nov.}

Forewings: apple-green, slightly varied with whitish, the costa narrowly pale; the lines paler ; first at one-third, slightly curved; second at three-fourths, straight, parallel to hindmargin; cell-spot ferruginous.

Hindwings: with outer line curved; cell-spot much larger than in forewings, elongated, ferruginous, with darker brown centre. Fringe in both wings white, with a fine ferruginous basal line.

Face and palpi ochreous below, rufous above; vertex white; antennae whitish; thorax and abdomen green, the latter with small white dots on back at the edge of the segments. Underside pale green, the costa of both wings broadly whitish.

Expanse of wings: $44 \mathrm{~mm}$.

One 3, one + , from Cedar Bay, south of Cooktown, Queensland (A. S. Meek).

Distinguished from $C$. meeki from Fergusson Island by the different coloured underside.

\section{Chrysochloroma subalbida rubritincta subsp. nov.}

A single $q$ from Humboldt Bay, New Guinea, must be regarded as, at least, a subspecies. In this example the discal spot of hindwings is a very large oblong ferruginous blotch; the apical angle of hindwings is marked with a large brown-red blotch; the dark brown basal line of fringes is much more developed, especially in the forewings, where the lunules that form it encroach upon the ground-colour of the wing, that above the anal angle forming a narrow brown-red blotch; the whitish fringes are tinged with red-brown opposite the veins.

\section{Chrysomphe gen. nov.}

Forewings: triangular; costa straight from base, curved before apex, which is produced and subfalcate; hindmargin faintly sinuous, with an almost imperceptible elbow at end of second median; anal angle rectangular.

Hindwings: with inner margin elongated; the hindmargin bluntly elbowed at the third median, above which it is faintly sinuous.

Antennae of $\delta$ subserrate, ciliated; face slightly prominent; palpi short, obliquely porrect; second joint squamous beneath, third short, blunt; tongue present ; hind tibiae of 8 rather thickened, with four short spurs. Frenulum present.

Neuration: forewings, cell not half as long as wing; discocellular angulated, the lower arm oblique, the upper bent in middle; first median at three-fourths; second and third shortly stalked; lower radial from the bend in the upper arm of discocellular; upper radial stalked with last four subcostals from end of cell ; first 
subeostal free, just before their stalk. Hindwings with last two medians and two subcostals stalked; radial as in forewings. Abdomen marked with three raised drops of golden scales; wings with semihyaline patches near base.

Type: Chrysomple venusta sp. nov.

\section{Chrysomphe venusta sp. nov.}

Forewings: dull mealy green, bluish-tinged, paler yellow-green at base along inner margin ; costa broadly ochreous straw-colour, the extreme edge whitish, speckled with reddish; a reddish blotch at base, and a reddish oblique streak at one-third indicating the origin of first line, which is only distinct again on inner margin as an olive-orange spot; a pale yellowish blotch beyond base reaching to beyond middle of wing, forming a sinus outward between the first and third medians, and not touching the inner margin; cell-spot dark green; second line at three-fourths, olive-orange, oblique and slightly curved; marginal area narrowly paler green, sometimes lemonyellow; fringe lemon-yellow, with a very fine orange line at base, and a red spot at apex of wing.

Hindwings: like forewings, but with a round pale yellowish blotch close to base.

Face, palpi above, fillet, and shaft of antennae red; palpi below white; vertex, thorax, and abdomen green; the abdominal tufts golden. Underside silky whitish green, with the pale patches yellowish; costa of forewing yellowish, with fuscous speckles and a red dash at apex; anal angle of both wings and apex of hindwings with the fringe dark olive mixed with reddish, above and below.

Expanse of wings: $30-36 \mathrm{~mm}$.

Five $\delta \delta$ from Cedar Bay, south of Cooktown, Queensland.

\section{Comostolodes deliciosa sp. nov.}

Forewings: bright blue; costa yellowish, with red and fuscous atoms; hindmargin with a row of bright rosy lunules, edged internally with yellowish white, and with a brilliant steely dot in the centre of each lunule on the hindmargin; fringe yellow.

Hindwings: the same.

Underside pale silvery blue, with the margins dull reddish. Face, palpi, vertex, and collar reddish; thorax blue; abdomen blue, with a broad reddish dorsal stripe.

Expanse of wings: $19 \mathrm{~mm}$.

One $q$ from Bunguran, Natuna Islands, October 1894 (E. Hose).

\section{Euxena gen, nov.}

Forewings: with costa well curved; apex rectangular; hindmargin strongly crenulate, vertical above, oblique below.

Hindwings: with inner margin lengthened, hindmargin crenulate; a deeper excision between veins 4 and 6 .

Antennae of $\delta$ quite simple; palpi porrect, reaching slightly in front of face, terminal joint short; tongue present; frenulum present; hind tibiae of $\delta$ with four spurs, hardly thickened; abdomen without tufts.

In forewings the first subcostal approximates to the costal, and again to the 
second, but does not anastomose; the last four subcostals stalked, the second rising before the fifth.

Type: Euxena crypsichoma sp. nov.

Distinguished from Chlorodontoperc Warr. by the simple antennae of the $\delta$ and the absence of abdominal tufts.

\section{Euxena crypsichroma sp. nov.}

Forewings: dull olive-green ; the costa red, dotted with black; the lines faintly darker, denticulated; first at one-fifth, very obseure; second from two-thirds of costa to two-thirds of inner margin; submarginal half-way between second and hindmargin ; fringe concolorous.

Hindwings: like forewings; both with an oval reddish grey ocellus, strongly edged with brown-black and pointed at the costal end.

Underside bright fulvous; forewings with a shining cinereous space below the median ; a dentate curved thick postmedian line dark fuscous; a dark fuscous marginal fascia, with the submarginal line clearly marked by fulvous lunules between the veins; hindwing the same, but without the postmedian line. Palpi and face blackbrown ; head, thorax, and abdomen olive-green.

Expanse of wings : $50 \mathrm{~mm}$.

One $\delta$ from Mt. Mulu, North Borneo, 1000-4000 feet (Charles Hose).

\section{Hemithea ornata sp. nov.}

8. Forewings: dull green; the costa and hindmargin broadly dull yellow; the costa speckled throughout with purplish brown atoms; the hindmargin with a row of broad similar-coloured dashes, interrupted at the veins, the fringe beyond yellow; both lines very fine and undulating, whitish, at one-third and two-thirds.

Hindwings: with the outer line only ; cell-spot darker green.

Underside gilded green. Face and palpi dull reddish; vertex white; thorax and abdomen green, the latter with red scales on back.

. With the yellowish border swollen across apex and at anal angle, it yellow ground-colour much freckled with brown throughout; the underside with a dark brown blotch at anal angle of forewings and apex of hindwings.

Expanse of wings : $\delta, 20 \mathrm{~mm}$; $\uparrow, 26 \mathrm{~mm}$.

Two $\delta$ ठ , two $q$, from Adonara, November 1891 (W. Doherty).

\section{Hemithea (?) punctifimbria sp. nor.}

Forewings: pale green (faded to yellow), with numerous paler strigulae; no trace of lines; fringe paler, with dark grey spots along the basal half opposite the veins.

Hindwings: the same.

The underside is unmarked, whitish green. Face and palpi reddish; thorax and abdomen green, the latter with red scales on the middle segments.

Expanse of wings : $20 \mathrm{~mm}$.

One $q$ from Bombay.

The type being a $\$$, the genus is doubtful; I plave it in Hemithea, because the first subcostal of forewings is free, and the abdomen is marked with red. The hindmargin of hindwings is only bluntly elbowed in middle, and the general aspect of the insect reminds one strongly of $N$ solidaria Guen. 


\section{Hemithea quadripunctata sp. nov.}

Forewings: dull yellowish green, subtransparent; costa ochreous, dotted with fuscous; first line at one-third, outcurved in cell and again below it, indicated by small dark dots on veins, the line itself threadlike and scarcely visible; second line at two-thirds, incurved in cell and on first median, the vein-dots linear; fringe concolorous.

Hindwings: the same, without the first line, and with a dark cell-dot.

Underside of both wings dull gilded yellow. Palpi green, with the tip brown; face pale ferruginous; head, thorax, and abdomen concolorous; second and third segments of abdomen each with a pair of red-brown dots, those on the fourth the larger, surrounded by a fuscous patch.

Expanse of wings : $32 \mathrm{~mm}$.

One $\delta$ from Oinainisa, November 1891 (W. Doherty).

Nearly related to $H$. subflavida Warr.

The antennae have rather strongly developed fascicles of cilia.

\section{Hemithea subflavida reducta subsp. nov.}

Like the type above, but smaller in size, the $f$ expanding only $26 \mathrm{~mm}$; ; on the underside the hindwings are marked with a broad blackish submarginal fascia, which is non-existent in subflavida Warr.; the black bloteh at anal angle of forewings is present in both forms.

One $\delta$, one + , from Cedar Bay, south of Cooktown, Queensland.

\section{Metallochlora dotata sp. nov.}

Forewings: pale apple-green; the costa yellowish, with a few reddish spots; a red-brown cell-spot; two slightly darker dentate shades, one in middle of wing, the other at three-fourths, forming the edges of a central fascia ; the outer edge of the exterior shade is marked on the upper radial by a red-brown linear spot; the yellow fringe has a row of minute reddish dots at base at end of the veins, and a small reddish blotch at anal angle.

Hindwings : similar, but without the red dot at the edge of the fascia.

Underside pale green. Palpi above and face dark brown; vertex, thorax, and abdomen green; the abdomen, instead of the metallic drops of $M$. flavifimbria Warr., is marked with shining red-brown spots.

Expanse of wings : $\delta, 26 \mathrm{~mm}$.;,$+ 28 \mathrm{~mm}$.

A pair from Port Mackay, Queensland.

The darker edges of the central fascia, which are well expressed in the $q$, are scarcely perceptible in the $\delta$.

\section{Metallochlora flavifimbria sp. nov.}

Forewings: bright apple-green; the costa finely yellow, with a few black dots; a minute brown-red cell-spot; fringe yellow.

Hindwings: the same, with the cell-spot crimson.

Underside pale yellowish green. Face and palpi above ferruginous; thorax and abdomen bright green; the drops silvery, edged with white scales. 
Expanse of wings: $22 \mathrm{~mm}$.

One $\delta$ from Geraldton, near Cairns, Queensland (A. S. Meek).

In this species the hindmargin of forewings is straight and oblique, of the hindwings obtusely angled.

\section{Metallochlora tenuilinea sp. nov.}

Forewings: olive-green; the costa broadly grey-green, with fine black dots at its edge; before the hindmargin is a fine curved silvery line, preceded by a very obscure dark green shade; a marginal line of black dashes hetween the veins; fringe metallic grey.

Hindwings: the same; discal spot dark green.

Underside hoary green, tinged with pinkish; a curved submarginal fascia on both wings, and an apical blotch on hindwings, black. Head, thorax, and abdomen green; the dorsal drops deep red.

Expanse of wings : $32 \mathrm{~mm}$.

One $\delta$ from Humboldt Bay, New Guinea, October 1892, taken by Doherty.

\section{Microloxia (?) coerulea sp. nov.}

Forewings: blue-green, the fringe concolorous; the lines white and broad; first at one-third, oblique inwards, slightly curved; second from costa at five-sixths to inner margin at two-thirds, straight and oblique; cell-spot indistinctly whitish.

Hindwings: with the outer line of forewings produced as a postmedian line, slightly curved inwards; cell-spot white.

Thorax and abdomen green; face, palpi, forelegs, and antennae bright ferruginous. Underside pale blue-green.

Expanse of wings : $24 \mathrm{~mm}$.

One of from Songive Valley, Lake Nyassa.

The position of the radials shows this species to belong to the Geometrinae; but in the hindwings the costal anastomoses for half the length of cell with the subcostal. In the forewings the first subcostal rises free, but soon becomes coincident with the costal ; the other four subcostals are stalked from just before the end of the subcostal nervure, which is then depressed, the upper radial rising from the end.

\section{Probolosceles gen, nov.}

Forewings: with costa nearly straight, convex before apex; hindmargin obliquely curved.

Hindwings : with hindmargin rounded; apex rounded; inner margin produced; anal angle well marked.

Antennae of $\delta$ pectinated; palpi longer in $q$ than $\delta$; frenulum present; hind tibiae of $\delta$ with four approximated spurs, and a long process from the end.

Neuration: forewings, cell hardly half as long as wing; last two medians from lower angle of cell; upper radial from upper angle; last four subcostals stalked, the fifth starting before the second. Hindwings with both subcostals and last two medians stalked.

Type: Probolosceles biplaga Wlk.

To this genus must be referred the species placed by Hampson under Nemoria, Sect. I. B. b., viz. Geometra detenta and dissessa Wlk., Comibaena quadrinotata Butler, and Comibaena integranota Hmpsn. 


\section{Probolosceles attenuata sp. nov.}

Like $P$. biplaga Wlk., but with the spots of quite different shape and larger in size; the inner edge of each sinuous (in biplaga it is straight); that in the forewings reaching to the third median, where it is attenuated and has a larger round blotch contiguous to it between veins 4 and 5 ; both blotches wholly brown, without pale centres.

One $\delta$ from Mt. Mulu, North Borneo, 1000-4000 feet (C. Hose).

This is the insect which Walker, after describing his typical biplaga, which was a $q$, suggests may be the $\delta$ and a variety of that insect. All his specimens were from Sarawak. Hampson in Faun. Brit. Ind. Vol. III. p. 504, at the end of his description of integranota, adds, "The $q$ has a black submarginal patch on forewings above vein 4." The $q$ in the British Museum Collection comes from Burma and belongs, I think, here.

\subsection{Thalerura (?) decorata sp. nov.}

Forewings: dull olive-green; the costa very minutely dark-dotted, and with a short fine red line just before apex; no distinct lines; a faint reddish spot on inner margin before middle denotes the first line, and a very obscure series of darker green blotches between the veins at four-fifths indicates the second; fringe white, tinged with reddish at apex and anal angle; hindmargin with a fine red line.

Hindwings: green, with a bright red cell-dot, and the red marginal line thicker and more diffuse; the tail wholly red; fringe white, reddish black round the tail, with a black tuft at base of the tail on both sides.

Underside pale green; fringes likewise, except round tail of hindwings, where they are blackish. Face and palpi pale ochreous; top of palpi and face and two dots at base of face bright orange-red; vertex and antennae white; thorax and abdomen green.

Expanse of wings : $26 \mathrm{~mm}$.

$q$ from Cedar Bay, south of Cooktown, Queensland (A. S. Meek).

\section{Subfamily STERRHINAE.}

\section{Anisephyra gen. nov.}

Forewings : with costa straight, convex just before apex; apex slightly produced; hindmargin sinuous.

Hindwings : with well-rounded hindmargin.

Forehead protuberant; palpi porrect, broad, squamous beneath, third joint small ; antennae of $\delta$ strongly pectinated to four-fifths, of $q$ simple; hind tibiae with four spurs.

Neuration: cells half as long as wings; discocellulars vertical ; in forewings the stalk of 10 and 11 anastomoses with that of $7,8,9$, to form the areole.

Type: Anisephyra rufaria sp. nov.

In this genus will come also albiannularia Wlk. 


\section{Anisephyra albiannularia incorrupta subsp. nov.}

Differs from the type-form with its variations in being entirely devoid of darker atoms or suffusion, both wings with their fringes being yellow; the ocelloid cell-spots distinct; in the forewings there are slight traces of a darker outer line, which in the hindwings is marked by dark dots on the veins.

Underside of both wings somewhat strigulated with darker, especially in the forewings ; outer line rather more distinct.

A long series, all exactly alike, from Dili, Timor, May 1892 (W. Doherty).

\section{Anisephyra rufaria sp. nov.}

Forewings: reddish testaceous, covered with fine short transverse darker striae, the striae more fuscous in the $\delta$; lines at one-third and two-thirds, in the $q$ deeper red, in the $\delta$ blackish, starting from costal blotches of the same colour, and both more or less obsolete between the median and submedian veins; fringe concolorous.

Hindwings: with the whole costal half fuscous, the reddish tinge confined to the inner margin and less intense; a dark curved postmedian line not reaching costa.

Underside dull grey, with a pinkish tinge. Palpi, face, thorax, and abdomen greyish, reddish-tinged, the thorax in $q$ quite reddish.

Expanse of wings: $26 \mathrm{~mm}$.

One $\delta$, one $q$, from Ajmere, Rajputana.

The forewings are narrower, in proportion to the size, than those of $A$. albiannularia Wlk.

\section{Chrysocraspeda croceomarginata sp. nov.}

Forewings: wholly deep rosy, except a narrow uniform marginal space which is pale yellow; the red colour forming a minute tooth into the yellow at vein 3 , but not reaching the fringe; fringe yellow; a very minute dark cell-dot.

Hindwings: the same; the cell-dot white.

Underside paler. Head, face, thorax, and abdomen all rosy.

Expanse of wings: $22 \mathrm{~mm}$.

One $q$ from South Java, 1891, 1500 feet (Fruhstorfer).

\section{Chrysocraspeda gibbosa sp. nov.}

Forewings: brownish grey, purple-tinged, the grey predominating along costa and hindmargin; the cell yellow, with ferruginous speckling and a black linear cell-spot; base of wing ferruginous; inner line indistinct, marked by blackish dots on veins; outer line indicated by a curved row of brown dots on veins, followed by an obscure pale yellowish line, succeeded by two dull reddish brown blotches, one opposite the cell, the other on vein 3 ; hindmargin red-brown; fringe yellow from apex to middle, then broadly red-brown at base with yellow tips.

Hindwings : pinker, becoming red-brown towards margin, with a paler waved submarginal line and traces of two dark median lines on inner margin; cell-spot white; fringe yellow throughout. 
Underside dull rosy grey, with cell and submarginal line on both wings yellowish. Palpi red; antennae pinkish; thorax pinkish grey; face damaged; abdomen wanting.

Expanse of wings : $26 \mathrm{~mm}$.

One $\delta$ from Tezpore, Assam.

Distinguished from all others of the genus by its peculiarly gibbous hindmargin, the inner margin being quite as long as the costal, the apex minutely produced; hindwings broad, with hindmargin nearly straight.

\section{Craspedia aequidistans sp. nov.}

Forewings: ochreous, thickly irrorated with very fine fuscous atoms; the lines dull fuscous, ending on inner margin at one-fourth, one-half, and three-fourths respectively; the first at one-third of costa, bent on the subcostal; central shade diffuse, from costa at three-fifths, incurved below middle; outer line darker, irregularly waved and bent, but without distinct denticulations; marginal line fine, dark fuscous, interrupted by the paler veins; fringe ochreous, dusted with darker; a small dark cell-spot.

Hindwings: with a diffuse antemedian shade, followed by the obscure cellspot ; submarginal and marginal lines as in forewings.

Underside whitish, the outer and marginal lines very distinct. Face and palpi fuscous above, ochreous below ; thorax and abdomen pale ochreous.

Expanse of wings : $30 \mathrm{~mm}$.

One $q$ from Oinainisa, Dutch Timor, December 1891 (W. Doherty).

\section{Craspedia nigristellata sp. nov.}

Forewings: greyish ochreous, slightly pink-tinged, and finely dusted with blackish atoms; the lines shown by deep black vein-dots; first line represented by three dots placed in a curve; outer line of dots approximated to hindmargin; the upper three oblique outwards; the fourth, on the lower radial, displaced basewards ; the remaining four in a curve parallel to hindmargin; marginal dots black; cellspot black, followed by an oblique curved grey shade.

Hindwings: the same, but the grey shade antemedian; the outer row of dots farther from the hindmargin; a pale submarginal line between two dark greyish shades,

Underside whitish, the forewings suffused with grey. Face and palpi dark brown ; vertex white; thorax and abdomen ochreous.

Expanse of wings : $24 \mathrm{~mm}$.

One $\delta$, four $q+$, from Batchian, May 1892 (W. Doherty).

\section{Craspedia subdecorata sp. nov.}

Forewings: glossy, bone-colour, sparsely irrorated with coarse fuscous atoms; the lines indicated by blackish scales and darker vein-dots; first line at one-fourth, curved above and vertical below; outer line at three-fourths, forming small dark teeth on the veins and strongly incurved opposite the cell; cell-spot obscure, ochreous, followed by a curved ochreous central shade; submarginal line of the pale ground-colour, with an ochreous waved fascia on either side; marginal spots large, black; fringe pale ochreous. 
Hindwings: the same; cell-spot minute, black, preceded by the ochreous shade.

Underside glossy, more whitish; the forewings suffused with grey from base; the central shade and a waved fascia beyond outer line dark grey; cell-spot and marginal spots distinct; hindwings with the markings fainter. Face and palpi brown; thorax and abdomen concolorous with wings.

Expanse of wings : $28 \mathrm{~mm}$.

One $q$ from Mt. Mulu, North Borneo (C. Hose).

\section{Craspedia subtincta sp. nov.}

Wings ochreous, with a reddish tinge, and dusted with grey, especially on basal half of hindwings; lines as in addictaria Wlk.; outer line of forewing dull ferruginous, followed in $\&$ by a greyish fascia; marginal line wavy, rarely interrupted.

Underside rufous ochreous in forewings, the costa brownish; the outer lines brownish; hindwings paler.

Expanse of wings : $22 \mathrm{~mm}$.

A long series from the Tenimber Islands, July 1892 (W. Doherty).

Distinguished from the allied forms by the rufous tint.

Dizuga gen. nov.

Forervings : with costa straight, rather strongly arched at base and convex before apex; apex blunt; hindmargin obliquely rounded.

Hindwings: with hindmargin erenulate, and with a deeper distinct excision opposite the cell.

Palpi as in Perixera; antennae of o pectinated; hind tibiae of o with four spurs.

Neuration: forewings, cell not quite half as long as wing; discocellular straight; first median at one-half, second before, third from, end of cell ; radials normal; all the five subcostals stalked from middle of cell, the fifth rising well before the end of cell. Hindwings with the two subcostals and last two medians from ends of cell.

Type: Dizuga parva sp. nov.

Distinguished by the four spurs of hind tibiae of $\delta$.

Anisodes illepidaria Guen. probably should be referred here.

\section{Dizuga parva sp. nov.}

Forewings: ochreous, slightly dusted with dark fuscous; first line formed by three black dots on veins; a black discal dot, with a smaller one before it in the cell; a faintly darker central shade, much outcurved beyond cell; exterior line formed by dots on veins, also much outcurved beyond cell; submarginal line of dots regularly curved, the dots between, not on, the veins, the second and fifth from the costa obsolete or very faint; a marginal row of dots between the veins; fringe ochreous.

Hindwings: the same, with a dark dot at base, and the dots towards inner margin enlarged. 


\section{$(.373)$}

Palpi externally bright rosy; face ochreous below, rosy above; vertex, thorax, and abdomen ochreous, the last with a dark spot on second segment. Underside of forewings bright rosy; of hindwings ochreous, tinged with rosy.

Expanse of wings: $22 \mathrm{~mm}$.

Two $\delta \delta$ from Cedar Bay, Cooktown, Queensland.

\section{Leptomeris (?) uniformis sp. nov.}

Forewings: rather glossy, pinkish grey, dusted with brown-red scales; marginal line of deep red dashes between the veins; fringe concolorous; cell-spot darker; lines hardly visible; traces of an inner line on inner margin at one-third, and of a slightly curved outer line at two-thirds, sinuate slightly inwards above inner margin; submarginal line denoted by small dots on veins.

Hindwings: like forewings, but with no lines visible.

Underside paler, in the forewings tinged with pink. Face reddish (damaged); thorax and abdomen concolorous.

Expanse of wings : $26 \mathrm{~mm}$.

One o from Mackay, Queensland.

A very obscure-looking insect, whose position, in the absence of the $\delta$, must remain doubtful.

\section{Lycauges mollis sp. nov.}

Forewings: uniform flesh-coloured ochreous, without dusting; cell-spot darker; the only line distinct is the denticulate outer one from near apex to inner margin beyond middle; submarginal line pale, between two slightly darker flesh-coloured bands; fringe concolorous.

Hindwings: with costal region whitish; a brownish cell-dot and three curved flesh-coloured submarginal lines.

Underside paler. Palpi ochreous; face dark brown; thorax and abdomen concolorous with wings.

Expanse of wings: $19 \mathrm{~mm}$.

One $\delta$ from the Khasias.

\section{Mesotrophe nephelospila (Meyr.).}

\section{Perixera nephelospila Meyr., Tr. E. S. 1889. p.487 (q).}

Mr. Meyrick, who made his description from a single $q$, at the end of it remarks that the dark anal blotch is probably variable. The examination of five examples, three $\delta \delta$, two $q \&$, from Cedar Bay shows that Mr. Meyrick's surmise was right, and also enables me to refer the species to its right genus. Only one $q$ example answers the description precisely; two others, a $\delta$ and $q$, have the dark tints at the anal angles much reduced; while in the remaining males there is no trace of any dark blotehes at all. In the type-form the basal segment of abdomen is also black. The structural peculiarity remarked by Meyrick in the bar between veins $1 a$ and $1 b$ of forewing holds in both sexes. As his description was made from a $q$ not in good condition, I append one made from a $\delta$.

$\delta$. Forewings: ochreous buff, thickly speckled with black atoms; the lines grey ; first twice curved and marked by black specks on veins; a faint oblique grey annulus, 
with a minute black dot at each end; an obseure curved greyish central shade; exterior line grey, with black dots on veins, nearer hindmargin than usual, followed by a cloudy grey shade forming blotches at anal angle, below middle, and apex; a marginal grey shade; a double marginal row of dots, those on veins smaller than those between; fringe pale ochreous.

Hindwings: like forewings; the cell-spot small, oval, of raised white scales.

Face and palpi rosy brown, beneath whitish; vertex, thorax, and abdomen ochreous; sides of abdomen rosy towards base. Underside ochreous, much suffused with rosy ; costa of forewings marked with fuscous.

\section{Organopoda olivescens sp. nov.}

Forewings: dull reddish, almost wholly suffused with olive-fuscous scales; the costa, base, hindmargin, and all the lines olive-fuscous; first at one-fourth, eurved and wavy; central shade diffuse, outwardly denticulate; exterior line irregularly denticulate, nearer the hindmargin than usual; submarginal line edged outwardly with paler reddish; fringe reddish, with a fuscous line along hindmargin, interrupted at ends of veins by slightly paler dots; extreme costa pale ochreous; cell-spot large, blackish.

Hindwings : the same.

Palpi bright rosy, pale beneath; face deep red-brown; thorax and abdomen like wings. Underside of forewings wholly dull rosy, with an ochreous subcostal streak and the inner margin whitish; of hindwings yellowish ochreous, tinged with rosy.

Expanse of wings: $28 \mathrm{~mm}$.

Two $\delta$ from Cedar Bay, Cooktown, Queensland (A. S. Meek).

Smaller and duller than either of the Indian species.

\section{Perixera confiniscripta sp. nov.}

Forewings: ochreous, finely irrorated with rosy ; first line marked by three veindots placed in an oblique line outwards; cell-spot small, blackish, followed by an obscure obliquely curved central shade; outer line close to hindmargin, taking the place of the submarginal, marked by blackish dots on veins, that on vein 5 large and cloudy and strongly displaced towards base; a row of dark marginal dots between the veins; fringe ochreous.

Hindwings : similar.

Underside paler; costal half of forewing suffused with rosy towards base. Palpi ochreous below, bright rosy above; face ochreous below, dark fuscous above; thorax and abdomen ochreous.

Expanse of wings: $22 \mathrm{~mm}$.

One $\delta$ from the Tenimber Islands, July 1892 (W. Doherty).

Distinguished by the position of the outer line, as well as by its much smaller size.

\section{Perixera (?) erubescens sp. nov.}

Forewings: wholly dull rosy red; with the cell-spot, a central shade, and the outer line slightly deeper red; the latter marked slightly with dots at the veins; fringe pale, with no trace of dark marginal spots or line.

Hindwing : the same, the cell-spot minute, white, and oval. 
Underside wholly dull reddish. Palpi whitish beneath, red above; face wholly red; fillet white; thorax and abdomen deep red.

Expanse of wings: $40 \mathrm{~mm}$.

One $q$ from Mt. Mulu, North Borneo (C. Hose). Another example, likewise a $q$, from Sandakan, North Borneo, has the basal half of costa broadly brown.

\section{Perixera (?) flavirubra sp. nov.}

8. Forewings: dull yellowish, but so densely dusted and suffused with brick-red as to appear red, the yellowish ground-colour only showing through in patches between the lines; first line very obscure, marked by black dots on veins; cell-spot minute, white, with a black edge; a cloudy straight dark central shade beyond it; second line marked by a sinuous row of dark dots on veins at five-sixths; submarginal line hardly denoted; fringe concolorous, with dark dots at ends of veins.

Hindwings: similar; the cell-spot larger.

Underside whitish, tinged with red in the forewings. Palpi white, bright rosy above; face white, with a rosy bar at top; antennae, rertex, thorax, and abdomen red.

The $q$ is wholly suffused with red, the yellowish ground-colour being quite obliterated; all the dark spots more prominent; the submarginal line with a double black blotch on each side of it opposite the cell in the forewings, and in the hindwings with the whole anal angle black. These black markings are, however, most probably, not sexual.

Expanse of wings : $32 \mathrm{~mm}$.

One $\delta$, one $q$, from Cedar Bay, Cooktown, Queensland (A. S. Meek).

Similar black markings to those occurring in this $q$ are mentioned by Meyrick in his description of the type of porphyropis, also a $q$; but that insect is pale ochreous, not suffused with red.

The hindlegs of the only $\delta$ are wanting, so that I have been obliged to query the genus.

\section{Perixera furcata sp. nov.}

Forewings: bone-colour, finely dusted with rosy atoms; first line curved, indicated by dots on veins; second at four-fifths, evenly curved, finely reddish, with dots at the veins; basal and apical fourth of costa dark red-brown; from the apical blotch a broad diffuse oblique red-brown fascia runs to middle of inner margin; from hindmargin opposite cell a similar streak runs horizontally to the oblique fascia, and is continued narrowly along the median vein half-way down the cell, where it throws out a blotch across the cell to the subcostal; a row of reddish brown marginal dots between the veins ; fringe bone-colour.

Hindwings: with a fine curved basal line, dotted on veins; a central thick red-brown fascia containing a blackish linear cell-spot; a curved outer line as in forewings; the horizontal blotch so swollen as to occupy the whole apical area.

Underside bone-colour, with a dull reddish tinge; cell-spot, oblique fascia, and outer line indicated, but more obscurely than above. Face and palpi bone-colour, dull reddish above; vertex, thorax, and abdomen bone-colour; collar red-brown; anal segments of abdomen dull red-brown, corresponding to the red-brown central fascia of hindwings.

Expanse of wings : $30 \mathrm{~mm}$.

One $q$ from Moroka, British New Guinea, October 1895, 3500 feet (Anthony). 
103. Perixera pallida Moore ab. ampligutta nov.

Among a long series of this species, all from Cedar Bay, Cooktown, several exhibit a marked difference from the type-form in having the discal spot of the hindwings developed into a long sinuous mark, edged with black, and filled up with shining whitish scales; in two of the whole of this space is coal-black. In all other respects they agree with the usual form.

\section{Perixera pallida Moore ab. perscripta nov.}

In this form the wings are not obscured by grey clouds, as in the type-form; but all the markings, especially the zigzag central line, are distinctly and concisely black, while the red dusting is very conspicuous.

Two of of from the Khasias, caught in December.

\section{Perixera roseofusa sp. nov.}

Forewings: ochreous, dusted with very fine rosy atoms; all the markings rosy, viz. the cell-spot, an indistinct shade beyond it, a dentate wavy outer line, and an obscure submarginal one; a double row of rosy marginal dots, those between the veins twice as large as those at the ends; fringe pale.

Hindwings: exactly the same, but with the cell-spot pale, triangular, edged with red.

Underside of forewings suffused with pale rosy, except the hind and inner margin; the cell-spot and two outer lines distinctly darker rosy; hindwings paler, with the two lines rosy. Face and palpi whitish, rosy above; head, thorax, and abdomen like wings.

Expanse of wings : $36 \mathrm{~mm}$.

One $\delta$, one $q$, from Mt. Mulu, North Borneo, 1000 -4000 feet (Charles Hose).

\section{Pisoraca sordidata sp. nov.}

Forewings: dull ochreous, dusted and suffused with grey; first line denoted by three black vein-dots; outer line at five-sixths, also formed by vein-dots, slightly connected by a darker shade; submarginal faintly paler, waved; a row of black dots at the ends of the veins; fringe concolorous; the hindmargin is strongly crenulate and very oblique in its lower half.

Hindwings: with a strong black cell-spot, followed by an obseure straight dark grey line; otherwise like forewings.

Underside of forewings dull brick-red, the inner margin whitish; of hindwings greyer red. Palpi ochreous below, bright red above; face ochreous below, brown above; vertex white; collar and thorax pale ochreous; abdomen greyer, with darker rings towards base; legs red.

Expanse of wings : $34 \mathrm{~mm}$.

One $\delta$ from Humboldt Bay, New Guinea, taken by Doherty, October 1892.

Plocucha gen. nov.

A development of Perixera, with which it agrees generally ; distinguished by having the costa of forewings in $\delta$ folded over flat and scaled, from one-fourth to three-fourths, much as in the genus Bardanes Wlk.

Type: Plocucha irregularis sp. nov. 


\section{Plocucha irregularis sp. nov.}

Forewings: yellowish ochreous, suffused with darker and dotted with pink ; first line very fine, threadlike, marked by dark red dots on veins, strongly angulated outwards in the submedian interspace; a dark discal dot at the upper angle of cell, preceded by another on the fold within the cell; an obscurely waved and dentieulate darker central shade; outer line threadlike, marked by distinct dark red veindots; these are placed somewhat irregularly; the fourth from the inner margin, on the third median, instead of being, as usual, in the same oblique line as the lower three, is situated vertically above the third, and the top three are strongly recurved to costa ; submarginal line pale, with a cloudy space on each side; a row of dark marginal spots between the veins, and of almost imperceptible dots at the ends; fringe concolorous.

Hindwings: the same, but with a whitish dark-edged discal ocellus, and the marginal dots at ends of veins plain.

Underside, especially of forewings, suffused with rosy, more deeply towards the margins; lines and marginal spots deeper red. Head, face, thorax, and abdomen ochreous; palpi red; abdomen with red dorsal spots.

Expanse of wings : $\delta, 28 \mathrm{~mm} . ; \quad$, $26 \mathrm{~mm}$.

A pair from Humboldt Bay, New Guinea, October 1892 (W. Doherty).

108. Problepsis margaritata sp. nov.

Forewings: dull white, dusted with coarse silvery scales; the markings very pale ochreous ; these consist of a curved inner line, very faint; a thick postmedian line, followed by three other lines, all four being curved towards costa ; cell-spot faintly darker ; fringe white, with a fine dark grey marginal line.

Hindwings: the same.

Underside wholly dull white. Face brownish grey above, becoming whitish below ; palpi pale ferruginous ; thorax and abdomen white.

Expanse of wings: $46 \mathrm{~mm}$.

One of from Brisbane, Australia.

Distinguished by the entire absence of ocellus.

\section{Ptochophyle inornata sp. nov.}

Forewings : reddish grey, dusted with darker and clouded in places with fuscous; lines very indistinct, indicated only by dots on the veins, first at one-fourth, second at three-fourths, the latter outcurved in midwing; a comparatively large blackish cell-spot; a row of marginal black dots ; fringe slightly paler.

Hindwings: the same.

Underside of forewings, except inner margin, dull rosy, with a faint pale submarginal faseia; inner margin and hindwing whitish; cell-spots dark in both wings. Palpi reddish; face and vertex white ; thorax and abdomen reddish.

Expanse of wings : $22 \mathrm{~mm}$.

Three $\delta$ o from the Tenimber Islands, July 1892 (W. Doherty). 


\section{Ptochophyle lineata sp. nov.}

Forewings: ochreous, densely irrorated with reddish striae; first line obsolete ; second line at two-thirds, strongly curved in the upper part, to inner margin at threefourths; fringe unicolorous, with no basal line or dots, but with reddish dots in the fringe opposite the ends of the veins; a small dark cell-spot.

Hindwings: the same, but with the cell-spot white with darker edge; hindmargin faintly crenulate.

Underside of both wings whitish, with a pink tinge, which is strongest along the margins. Face and vertex white; thorax and abdomen concolorous with wings.

Expanse of wings : $22 \mathrm{~mm}$.

Three ơ ठे, one $q$, from Dili, Timor, May 1892 (W. Doherty).

\section{Ptychopoda deflavaria sp. nov.}

Forewings: yellow ochreous, with fine dark dusting; the lines much as in remotata Guen., but the outer line not so dentate; marginal area clouded with grey; a marginal row of minute black dots ; fringe concolorous.

Hindwings: the same, but the central line thickened; both wings with small black cell-spot.

Underside whitish ochreous; the forewings yellow-tinged along costal half. Palpi yellowish, with the last joint dark brown; face dark brown; thorax and abdomen like wings.

Expanse of wings : $22 \mathrm{~mm}$.

Three $\delta$ o from the Tenimber Islands, July 1892 (W. Doherty).

Distinguished at once by the strong yellow ground-colour.

\section{Ptychopoda nigranalis sp. nov.}

Like actiosaria Wlk.; pale bone-colour, dusted with darker, with the lines similar; distinguished by the outer line of both wings ending on inner margin in a small blackish blotch; the submarginal line also in the forewings dark on inner margin.

One $\delta$ from Dili, Timor (type); two $f$ f from Wetter, May 1892 (W. Doherty).

\section{Ptychopoda pallidivestis sp. nov.}

Forewings: bone-colour ; first line brown, indistinct, marked on costa by a dark spot; exterior line at three-fourths, concise, strongly denticulate, parallel to hindmargin, starting from a large dark brown costal spot; marginal area tinged with fuscous, the lower half darker, with fuscous lunules; fringe bone-colour, with a row of small dark dots at base; cell-spot large, black.

Hindwings: the same.

Underside like upper, but duller. Face and collar black; thorax and abdomen ochreous.

Expanse of wings: $12 \mathrm{~mm}$.

One $\delta$ from East Java.

The antennae have very long ciliations. 


\section{Rhodostrophia inornata sp. nov.}

Forewings: mouse-colour, with an undertone of reddish; basal area rather darker, edged by an obscure curved line at one-fourth; cell-spot round, black; a eurved, uniformly broad, darker fascia beyond it; exterior line at five-sixths, dark brown, evenly curved and denticulate; fringe concolorous, with darker basal line.

Hindwings: the same, but the discal spot elongated and accompanied by two or three whitish dots.

Face and palpi dark brown-red; thorax and abdomen concolorous with wings; vertex and antennae paler. Underside paler; both wings suffused with rufous except along hindmargins.

Expanse of wings : $32 \mathrm{~mm}$.

One $\delta$, one + , from Bandong, Java.

\section{Somatina rufifascia sp. nov.}

Forewings: greyish ochreous, olive-tinged; a deep red fascia at and beyond the centre, its edges waved, with a curved line down centre within which the red is deeper; the red tint fades into olive above the cell, only the edges remaining red and reaching the costa; submarginal line white, irregularly waved, preceded by a darker olive tint, containing two red-black blotches, one on each side of the upper radial, and two more above anal angle; a marginal line of curves, white, preceded and narrowly followed by olive, with two cloudy reddish blotches below apex and some red scales at anal angle; fringe glossy ochreous; a small dark cell-dot in the red fascia.

Hindwings: with the fascia olive, its inner edge diffusely reddish, and its outer only red at inner margin; submarginal and marginal lines as in forewings, but without any red blotches.

Underside milk-white, with black cell-dots and three or four black marginal dots towards apex of each wing. Palpi and face pale below, brownish above; fillet reddish brown; collar ferruginous; thorax cream-colour; abdomen cream-colour, tinged with reddish grey.

Expanse of wings: $32 \mathrm{~mm}$.

One $q$ from Cedar Bay, Cooktown (A. S. Meek).

\section{Somatinopsis gen. nov.}

Like Somatina in all essential points, but the hind tibiae of $\delta$, as well as the tarsi, not abbreviated; the tibiae with a terminal pair of spurs; antennae shortly eiliated.

Type: Somatinopsis nigridiscata sp. nov.

\section{Somatinopsis nigridiscata sp. nov.}

Forewings: whitish, dusted with black scales; a large blackish cell-spot; an irregularly dentate dark exterior line at five-sixths, incurved opposite the cell; a blackish subapical costal blotch; a row of black dots between veins before the hindmargin ; fringe concolorous. 
Hindwings: similar; the cell-spot smaller; the exterior line more regularly denticulate.

Underside the same, but whiter and more glossy. Face and vertex blackish; palpi (?); thorax and abdomen like wings.

Expanse of wings: $36 \mathrm{~mm}$.

One $\delta$ from South Java, 1891, 1500 feet (Fruhstorfer).

\section{Stibarostoma gen. nov.}

A development of Perixera Meyr., distinguished from it and all other of the allied genera by the remarkably developed palpi; in these the second joint is three times as long as the head and correspondingly stout, thickly clothed with hair beneath, porrect, towards the end becoming decumbent; third joint decumbent, short and blunt, smoothly scaled; the hind tibiae of $\delta$, as in Perixera, with two spurs; the hind femora simple.

Neuration: as in Perixera.

Type: Stibarostoma griseata sp. nov.

\section{Stibarostoma griseata sp. nov.}

Forewings: greyish ochreous, covered with pinkish atoms; the costa dark greyish; first line marked by three black dots on the veins, the lower portion also by a diffuse grey streak; a diffuse oblique and somewhat waved central grey shade; exterior line shown by black vein-dots on an obscure curved grey line; followed by a subterminal and marginal grey fascia, the former interrupted opposite the cell and below the middle; a marginal row of black spots at ends of veins and minute dots between them; fringe pale clear ochreous.

Hindwings: the same; no cell-spot on either wing.

Underside shining ochreous, tinged with flesh-colour; the central and two outer lines expressed; the marginal dots and dots of the exterior line purple, the latter with the three nearest the costa close together and distinct; cell-marks just indicated. Palpi whitish ocbreous below, bright rosy above; face, vertex, thorax, and abdomen ochreous, the last dusted with darker, and with dark dorsal spots.

Expanse of wings: $30 \mathrm{~mm}$.

Three $\delta \delta$ from Cedar Bay, Cooktown.

Superficially resembling $P$. pallida Moore, but larger and without discal spots.

\section{SUBFAMILY TRICHOPTERYGINAE.}

\section{Coptogonia gen. nov.}

8. Forewings: with costa curved at base and apex, faintly incurved in middle; apex blunt, rectangular; hindmargin straight and vertical to below third median, then sharply but shallowly excised to above first median; the anal angle lobed; the inner margin sinuous; vein 1 running to middle of inner margin, and there followed by a round hyaline blister.

Hindwings: as in Remodes Guen., with three lobes.

Antennae lamellate, thickened; palpi porrect, twice as long as head, the second 
joint long and hairy, the third slender and smooth; hind tibiae shortened and swollen, without spurs; hind tarsi also thickened at base; abdomen with tufts of hair.

Neuration: forewings, cell half as long as wings; first median at three-fourths, second half-way between first and lower end of cell ; radials normal; the areole long; first subcostal from close to its end, the fifth from a little beyond the end, the other three separating near the costa. The hindwings of the only example are too much broken to admit of the neuration being made out.

Type: Coptogonia turpipennis sp. nov.

\section{Coptogonia turpipennis sp. nov.}

Forewings: olive-green, with a strong rufous tinge; traces of dull reddish fasciae, most distinct on costa; the first close to base, the second and third on each side of the middle, the last two submarginal and narrower, darker beyond the cell; traces of purplish spots at ends of veins from apex to middle; fringe rufous olive.

Hindwings: pale ochreous, the terminal lobe dark fuscous.

Underside greyish ochreous. Palpi ochreous olive; face brown; antennae blackish; thorax and abdomen olive ochreous.

Expanse of wings : $38 \mathrm{~mm}$.

One of from Batchian, March 1892 (W. Doherty).

The insect described is unfortunately somewhat worn, and an exact description is impossible.

\section{Helminthoceras gen. nov.}

Distinguished from Sauris, Remodes, and their allies by the formation of the antennae; these are lamellate and laterally flattened, the upper edge with four distinct curved swellings, each with short tufts of scales; palpi long, the second joint with loose scales, the third smooth.

Type: Helminthoceras sinuaticomis sp. nov.

\section{Helminthoceras sinuaticornis sp. nov.}

Forewings: very pale greenish, with diffuse transverse wavy fuscous lines, most distinct towards inner margin ; the outer line dentate and angled outwards in midwing, preceded by fuscous scales, which in the lower half of wing reach the straight central line and form a more or less distinct dark central fascia, the dark cell-spot lying in the unsuffused greenish upper half; an indistinct fuscous submarginal line, joined by fuscous scaling opposite the cell to the outer line; apical space pale green, unclouded.

Hindwings : pale greenish grey.

Underside pale greenish grey. Face brown ; palpi dull olive-green ; thorax and abdomen green; antennae fuscous ochreous.

Expanse of wings: $26 \mathrm{~mm}$.

One $q$ from Humboldt Bay, New Guinea, October 1892 (W. Doherty). 


\section{Remodes (?) angulosa sp. nov.}

Forewings: pale greyish green, olive-tinged, the markings dull purple; a wavy dark purple line near base, followed by two broad zigzag olive-green shades; then a pale dentate fascia with a central dark line, followed by a double dentate purplish line forming the inner edge of the central fascia ; discal spot oblique, purple, touching the inner edge of fascia ; outer edge formed of two deeply dentate purplish lines, oblique outwards below costa and excurved round cell; then an olive fuscous externally dentate fascia broad on costa and becoming a line on inner margin, the teeth filled up with purplish; next a pale curved fascia with dark green central line; a dark green fascia with strong purple wedge-shaped marks between the veins; the submarginal line pale green and dentate ; another purplish fascia before margin ; a row of dark dots at end of veins; fringe green.

Hindwings: fuscous grey.

Underside dull grey. Palpi and antennae black; vertex and thorax olive-green ; abdomen cinereous.

Expanse of wings: $34 \mathrm{~mm}$.

Two $q q$ from Amboina, February 1892 (W. Doherty).

Distinguished especially by the strongly dentate character of all the lines. Though I have placed it under Remodes, I am by no means sure of its proper place in the absence of the $\delta$.

\section{Subfamily ASTHENINAE.}

\section{Bardanes flavata sp. nov.}

Forevings: yellow ; costa purple-brown, with yellow intervals; in $\delta$ wholly ferruginous ; the markings ferruginous, the only distinct line being one just beyond the middle of forewings; all the usual waved lines more or less obsolete, especially in the $\delta$.

Hindwings: with the line central and often broken; fringes of both wings yellow, sometimes with ferruginous dots at end of veins.

Face, vertex, and collar ferruginous; fillet white; thorax and abdomen yellow. Underside duller yellow, with the central line dull rosy brown.

Expanse of wings : $26-30 \mathrm{~mm}$.

Two $\delta \delta$, four $q \circ$, from West Java.

\section{Bardanes nigricosta sp. nov.}

Forewings: greyish ochreous, slightly pink-tinged, with fine rosy irroration ; a small brown blotch on costa near base; first line strongly angled, marked only by dots on veins; one on costa just beyond the subbasal blotch, a small one obliquely outward on subcostal, and a third beyond it in cell; the fourth at the base of first median nervule, and the fifth on the submedian near base; outer line at four-fifths, indicated by black dots on veins, the upper two being included in a large brown-black costal bloteh; the costal fold strongly marked with brown-black; a row of black marginal dots between the veins, and minute points at the ends; fringe concolorous; cell-spot large, brownish. 


\section{$(383)$}

Hindwings: the same; cell-spot lunulate, edged with brown, and followed by an obscurely darker central shade, which can also be faintly discerned on the forewings.

Underside whitish, tinged with rosy towards costa in both wings; the outer line marked with dark vein-dots in the costal half. Face, vertex, thorax, and abdomen pinkish grey; palpi dull red above.

Expanse of wings : $30 \mathrm{~mm}$.

One $\delta$ from Humboldt Bay, New Guinea, October 1892 (W. Doherty).

\section{Cleptocosmia gen. nov.}

Forewings: with costa nearly straight, slightly curved at base and just before apex, which is somewhat produced and acute; hindmargin obliquely curved, bent in the middle, the lower part more oblique than upper and slightly excised above anal angle.

Hindwings: kite-shaped, the hindmargin with a prominent elbow in middle.

Antennae of $\delta$ lamellate, finely pubescent; palpi very short; tongue present; hind legs of $\delta$ fully developed; the tibiae with four spurs, the two outer ones long and hairy, the tibiae themselves also hairy; a very long straggling tuft of hair from base of hind tibiae. Forewings of $\delta$ with a rather large hyaline fovea, and with the basal half of wing clothed with erect furry hair.

Neuration: as in Chrysocraspeda, the five subcostals on one stalk.

Type: Cleptocosmia mutabilis sp. nov.

\section{Cleptocosmia mutabilis sp. nov.}

8. Forewings: yellowish, overlaid with dull red and crossed by wavy diffuse reddish grey lines, which are only visible towards the hindmargin, the basal half being covered, except just at base of costa, by the fulvous furry hair ; fringe yellow beyond a reddish, slightly crenulated, marginal line.

Hindwings: with the cross-lines visible throughout.

Underside dull rosy. Fillet and base of antennae white. Face, vertex, thorax, and abdomen dull ferruginous.

Expanse of wings : $24 \mathrm{~mm}$.

One $\delta$ from Cedar Bay, Cooktown (A. S. Meek).

\section{Hydrelia pallidula sp. nov.}

Forewings: pale ochreous, with traces of waved brown lines across the wing; cell-spot ferruginous; a row of ferruginous spots at end of veins; fringe ochreous.

Hindwings : similar.

Underside whitish, the costa of forewings ferruginous at base. Palpi and face ochreous, ferruginous above; thorax and abdomen ochreous.

Expanse of wings : $26 \mathrm{~mm}$.

One $q$ from South Java, 1891, 1500 feet (Fruhstorfer).

I leave this at present in Hydrelia; but the neuration is peculiar. Veins 10 and 11 , and $7,8,9$ are stalked; 10 and 11 first anastomose with the stalk of the other three, and subsequently 8 and 9 abruptly leave 7 and anastomose again with 10 . In both wings the cell is very short, vein 3 rising before the lower end; the two subcostals of hindwings are shortly stalked. 


\section{Psilocambogia semirubra sp. nov.}

Forewings: yellow, with the base, the costa, a large postmedian costal blotch, reaching below the median and there bilobed, and a smaller narrower subapical streak, all blood-red; fringe yellow.

Hindwings: wholly yellow, deeper towards the fringe.

Underside pale yellow, with the markings brown. Face, vertex, and shoulders deep ferruginous; fillet and antennae snow-white; collar yellow; thorax and abdomen reddish mixed with yellow.

Expanse of wings : $18 \mathrm{~mm}$.

One $\delta$ from Humboldt Bay, New Guinea, October 1892 (W. Doherty).

\section{SUBFAMILY HYDRIOMENINAE.}

\section{Anticlea canaliculata sp. nov.}

Forewings: whitish grey, finely dusted with dark grey; a chestnut basal patch edged by the curved and inwardly oblique basal line; first line treble, starting from a chestnut blotch on costa before middle, at first angled inwards, then running outwards to the median vein, then again sharply angled and becoming obsolete to the inner margin at middle; outer line double, at two-thirds, also starting from a chestnut costal blotch, running at first obliquely outwards nearly to hindmargin, then strongly bent inwards to the end of cell, where it meets the angulations of the first line, thence to inner margin describing four long reddish teeth; submarginal line from a large costal blotch, wavy to the median, then strongly dentate, and approximating to the outer line; hindmargin greyer; all the lines are slightly chestnut-tinged, especially the submarginal, and the veins beyond the middle are also reddish; in the pale space between the basal patch and central fascia are two or three faint undulating grey lines, and between the central faseia and the submarginal line is a single fine line; cell-spot linear, oblique; an interrupted dark reddish grey marginal line; fringe grey, tinged with red; the inner margin between the edges of the central fascia is filled up with grey.

Hindwings: white; a very faint eurved grey submarginal line; fringe white, slightly tinged with grey towards anal angle, and preceded on margin by two or three pairs of dark dots.

Underside whitish, in the forewings tinged with dirty rufous, especially towards apex ; face and palpi chestnut ; collar, thorax, and abdomen mixed grey and chestnut. Expanse of wings: $36 \mathrm{~mm}$.

One $\delta$ from Sikkim (Pilcher leg.).

The costa of forewings at base is rough-haired.

\section{Coenocalpe (?) legalis sp. nov.}

Forewings: with ground-colour whitish ochreous, but so much suffused and dusted as to appear red-brown; crossed by numerous minutely dentate red-brown lines; costa dotted pale and dark; two or three dark sharply angulated lines close to base, followed by a red-brown fascia with pale edges before the central fascia, of which the inner edge is angled in the cell and on the submedian fold; outer edge from just beyond middle of costa to middle of inner margin, curved and minutely waved and 
denticulated; the space between the edges black-brown; outer edge margined with pale and followed by four or five exactly similar red-brown lines separated by pale intervals; submarginal line obscure, waved, preceded by a curved red-brown shade which narrows downwards; hindmargin and fringes reddish; marginal line crenate, black; the veins beyond the middle are dotted dark and light.

Hindwings: like forewings, but with no dark central fascia.

Underside white, with the costa and cell of both wings yellow; forewings with three or four vertical black streaks across the middle, the outermost angled in middle and followed by a pale band, beyond which the whole margin is blackish except a small spot at apex and middle of hindmargin; hindwings with indistinct cross-lines, except the outermost, which is broad and angled. Head, thorax, and abdomen all reddish grey.

Expanse of wings: $39 \mathrm{~mm}$.

One $\&$ from Lifu.

\section{Collix multifilata sp. nov.}

Forewings: reddish ochreous, suffused with fuscous, and crossed by numerous fuscous lines, all more or less strongly denticulate; the costa more reddish; the line limiting the basal patch and those edging the central fascia thicker and forming costal blotches; submarginal line double, its outer arm formed of thick double lunate blotches, the inner with black dots on veins; two lines close to base, and a line before and beyond the central fascia; the latter, like the outer line of fascia itself, marked with dark dots on the veins; a dentate line within the fascia preceding the outer edge; marginal area with a dark dentate line, joined to marginal line by black dashes; fringe dark fuscous, with bright ochreous dashes opposite the veins; a large black cell-spot of raised scales.

Hindwings: the same.

Palpi reddish ochreous, externally black; face black below, mixed with ochreous above; front of head and thorax and base of patagia blackish; rest of patagia ochreous; abdomen reddish ochreous, ringed and spotted with blackish. Underside grey, with the cell-spots and two outer fasciae thick and blackish.

Expanse of wings: ठ , $26-28 \mathrm{~mm}$.; $\uparrow, 32 \mathrm{~mm}$.

In large numbers from Cedar Bay, south of Cooktown, Queensland.

\section{Collix subligata sp. nov.}

Forewings: reddish grey, with dark fuscous markings; two or three dark curved lines at base; a dark central fascia, its edges formed of two or three wavy lines, more or less coalescent below, but leaving a paler central space above in which lies the sinuous black cell-spot; submarginal line reddish ochreous, wavy, preceded by a broad fuscous fascia which is interrupted between veins 3 and 4 ; margin brown; the veins paler, with dark horizontal dashes between them; marginal line black; fringe reddish.

Hindwings: the same.

Underside glossy whitish; the cell-spots large; two postmedian thick purpleblack velvety curved lines which are partially interlaced. Palpi reddish grey, the tips blackish; face dark; head, thorax, and abdomen dark cinereous.

Expanse of wings : $36 \mathrm{~mm}$.

One $\&$ from Lifu. 


\section{Gonanticlea multistriata sp. nov.}

Forewings: pinkish brown, with deeper brown lines and fasciae; the edge of basal patch and the edges of the central fascia formed by dark velvety brown fasciae traversed by blackish lines; edge of basal patch sinuous, the patch crossed by three dark brown lines; inner edge of central fascia sinuous, incurved below costa and above inner margin; space between basal patch and central fascia pinkish brown, traversed by two dark brown lines; its extreme edge marked by a slightly lustrous grey line; inner brown band of central fascia traversed by three dark blackish brown lines; outer band also by three lines; the narrow central space pinkish brown, traversed by one brownish line; outer edge of central fascia wavy, followed by a lustrous dark-edged line, which is succeeded by a darker brown minutely waved line, from which an oblique dark brown blotch runs into the apex; submarginal space pinkish brown, with three darker lines; the extreme margin darker, with two or three lunules above anal angle; the last four lines are dentate below the costa; fringe dark brown, with a blackish line at base.

Hindwings: bright coppery orange, tinged with blackish along inner margin and hindmargin; fringe dark brown, with black line along base.

Head, face, thorax, and abdomen reddish brown, the thorax mixed with paler, the abdomen with darker segmental rings. Underside of forewings dull orange, with the apex fuscous; of hindwings dull orange, speckled all over with fuscous, with two curved fuscous lines and a black cell-spot.

Expanse of wings : $42 \mathrm{~mm}$.

One $q$ from West Java.

\section{Perizoma rubridisca sp. nov.}

Forewings: dull rust-colour; the basal area, costa, apical area, and a small blotch above anal angle purplish grey; the grey basal blotch is crossed by three or four curved darker lines; the costa is marked with dark grey; the outer line, shaped as in seriata Moore, is denoted only by double dark dots on the veins; the submarginal line in the apical blotch is margined with blackish; marginal line composed of pairs of dark spots; fringe rust-coloured, but dark grey along the apical blotch.

Hindwings: fuscous, with marginal line as in forewings.

Underside dull dark grey, rufous-tinged in forewings. Head, thorax, and abdomen purplish grey.

Expanse of wings : $26 \mathrm{~mm}$.

One $q$ from Sikkim (Pileher leg.).

\section{Perizoma seriata Moore ab. fulvistriga nov.}

Differs from the type-form in having the submarginal line fine and evenly waved throughout, instead of being broken up into round spots; and instead of the large white (or rufous) blotch at middle of hindmargin, a horizontal yellow streak from outer line to margin.

One $q$ from Darjiling (Pilcher leg.). 
133. Polyphasia calamistrata Moore ab. albimedia nov.

Differs from the type-form in having the dark median fascia broken up by white scaling, the upper part sometimes being wholly white with the black cell-spot prominent in the middle. The hindwings pure white, whereas in calamistrata they are always more or less tinged with grey.

Several examples from Sikkim.

\section{Polyphasia cinereata Moore ab. flavifusa nov.}

Like cinereata Moore, but with the greyish white tints of the middle area replaced by dull yellowish. The form is analogous to the European commanotata.

Several from Sikkim.

\section{Polyphasia dentifera sp. nov.}

Forewings: pale dull yellowish; basal area greyish, with the lines blackish; outer edge of median band velvety black, edged with white below the costa, and strongly toothed in its lower half; the submarginal line forming a velvety black wedge-shaped mark on the submedian vein at anal angle.

Hindwings: yellowish grey.

Face and thorax yellowish grey; abdomen cinereous.

Expanse of wings: $42 \mathrm{~mm}$.

One $q$ from Darjiling (Pilcher leg.).

A very large form and very distinct from any other.

\section{Triphosa acutipennis sp. nov.}

Forewings: dull grey, with numerous darker indistinct wavy cross-lines; the veins spotted blackish and pale; first line at one-third, curved and irregularly wavy, starting from a blackish spot on costa, which is followed closely by another blackish spot connected with the black cell-spot; second line at two-thirds, wavy, and darker towards costa, angled below veins 7 and 4, then slightly incurved; marginal area darker grey; the submarginal line not expressed; fringe grey; the hindmargin subcrenulate.

Hindwings: paler grey, without markings, except on inner margin above anal angle, where traces of three or four dark wavy lines are present; the veins spotted dark and light; fringe grey.

Underside shining dull pale grey, with traces of the darker markings showing through. Face and palpi dark fuscous; thorax and abdomen grey.

Expanse of wings: $52 \mathrm{~mm}$.

Three of from Kumaon (Pilcher leg.).

Resembling the grey form of the European $T$. dubitata, but distinguished by the more pointed forewings.

\section{Triphosa pallescens sp. nov.}

Forewings: whitish grey, suffused with darker grey and with blackish markings; the base dark grey; first line at one-third, angled below costa, then oblique and slightly wavy inwards, followed by a similar line which passes through the dark 
cell-spot; second line at two-thirds, bluntly angled below costa and forming a strong acute angle below vein 4 ; the line is preceded by a blackish suffusion, especially towards costa; three blackish costal spots before apex; veins obscurely marked with pale and dark; submarginal line very faint, indicated by pale spots, one larger and more distinct towards anal angle; marginal line black, crenulate, interrupted by a small pale dot at ends of veins; fringe grey.

Hindwings: pale grey, darker towards margin; a distinct regularly waved dark postmedian line, with traces of a central line; veins dotted dark and pale.

Underside duller grey, with the markings indistinct. Face and palpi black; thorax and abdomen dark grey.

Expanse of wings: $45 \mathrm{~mm}$.

One of from Kumaon (Pilcher leg.).

\section{Xanthorhoë farinata sp. nov.}

Forewings: grey, with very fine dark irroration; the lines blackish; first near base, angled in cell and preceded by a finer line; second line beyond one-third, angled on the subcostal, then oblique inwards and waved to inner margin before middle, followed by a similar finer line, the two marked with black on the median; outer line at two-thirds, angled on vein 6 , bidentate below median, then incurved and wavy, preceded by a similar finer line; submarginal line pale grey, denticulate, with a darker grey shade on both sides; fringe grey, slightly mottled with dark, with no dark basal line; in the pale spaces before and beyond the central fascia, and in that fascia itself, traces can be seen of darker transverse lines; the space between the double lines forming the edges of the central fascia is filled up with blackish from the costa to the angulation.

Hindwings: paler grey, with traces of a sinuate still paler submarginal fascia with a dark line through it.

Underside grey, with the outer line blackish. Head, thorax, and abdomen all grey ; forelegs blackish, with white joints.

Expanse of wings: $26 \mathrm{~mm}$.

Two $\delta$ o from Wellington, New Zealand.

This insect has a somewhat furry appearance; the costa is slightly shouldered at about one-sixth from the base. Distinguished from cinerearia Dbld, and semisignata Wlk., first by the uniform coloration of the wings, the veins of which are never dotted and spotted with dark and light; and, secondly, by the entire absence of a dark basal line to the fringes. In cinerearia Dbld., which is smaller, the basal line consists of pairs of black dots; in semisignata Wlk., which is a larger species, the veins are strongly dotted, and the fringe-line consists of black dashes.

\section{Xanthorhoë perviridis sp. nov.}

Forewings: dark greyish green, suffused with dull purple; the first and second lines, at one-third and two-thirds respectively, double and sinuous, the whole wing crossed by fine wavy dark lines which are only distinct as dark spots on the veins, giving the wings a reticulated appearance; fringe concolorous; marginal line formed of small black interrupted dashes.

Hindwings: dark fuscous grey, becoming slightly rufous towards base; traces of a paler double submarginal line towards anal angle. 
Underside dull dark cinereous, with the outer lines and marginal area dull blackish. Face rufous ochreous; palpi dark green; thorax and abdomen dark green, the former slightly, the latter considerably, varied with rufous ochreous; antennae dark green.

Expanse of wings: $36 \mathrm{~mm}$.

In some numbers from Newcastle, Jamaica.

Though apparently common, I have not been able to find a description of this species.

\section{Subamily TEPHROCLYSTINAE.}

\section{Chloroclystis leucopygata sp. nov.}

Forewings: red-brown, suffused in parts with fuscous; basal patch small, followed by a curved pale fascia, with a dark central line; inner edge of central fascia curved, wavy; outer edge irregularly wavy, angled on vein 4, and edged by a pale line, followed immediately by a dark one; this central fascia is darkest on the costa and towards its outer edge, and is traversed by three or four waved paler lines; cell-spot black; submarginal dentate, finely whitish, preceded by blackish blotches at costa, opposite the cell, and above inner margin ; fringe concolorous, with some finely paler dark-edged markings at base; veins throughout spotted, dark and light.

Hindwings: similar, but the submarginal line whiter, with one distinct white tooth below vein 4 , and preceded by a distinct denticulate black line.

Underside whitish, blotched with dark fuscous; cell-spot and a broad strongly angulated outer line blackish; marginal area blackish, with submarginal pale spots. Head, thorax, and abdomen red-brown, the last with the anal segment white.

Expanse of wings : $30 \mathrm{~mm}$.

Two of from the Khasias, November 1895.

The hindmargin of the forewings is slightly, that of the hindwings distinctly, crenulate.

\section{Chloroclystis semivinosa sp. nov.}

Forewings: whitish, with rufous fuscous markings; middle third of wing occupied by a fuscous fascia with darker denticulate edges, both curved, and the outer slightly angled, with traces of other denticulate lines between; the outer dark edge followed by a whitish line; marginal area suffused with rufous fuscous, through which a wavy pale submarginal line can be traced; marginal line dark, interrupted at the veins; fringe grey, with paler base, and yellowish dashes at end of veins.

Hindwings: suffused with vinous red, the base paler; a broad diffuse red central fascia, with the veins marked with coarse black seales, and edged externally by a red line, followed by a narrow pale fascia; marginal area reddish, mixed with grey, preceded by a reddish line; the submarginal line wavy, paler, with the teeth internally dark-edged.

Underside rufous cinereous. Head, thorax, and abdomen ochreous, the abdomen tinged with reddish grey.

Expanse of wings: $14 \mathrm{~mm}$.

One $\&$ from East Java, 1892 .

Distinguished by the colour of the hindwing: 


\section{Chrysoclystis gen. nov.}

ๆ. Forewings: with costa faintly curved; hindmargin well rounded.

Hindwings : with rounded hindmargin.

Antennae of $q$ simple, filiform; palpi three times as long as head, obliquely decumbent, laterally flattened; second joint squamous; third as long as second, narrow at base and apex, swollen between; forehead with a prominent cone of scales below ; tongue present ; hind tibiae of $q$ with four spurs.

Neuration: as in Chloroclystis; the first and second subcostals of forewing stalked, the first anastomosing with the costal, the second with the stem of the other three. In the hindwings the discocellular is oblique, the radial from the centre; the two subcostals short-stalked; the second median from before the end of cell. Scaling smooth, the markings oblique and metallic.

Type: Chrysoclystis perornata sp. nov.

142. Chrysoclystis perornata sp. nov.

Forewings: fulvous yellow, without striations; the costa broadly paler; a subcostal line of interrupted patches of red-brown and brilliant silvery scales; the lines oblique; the first from below costa before middle to inner margin near base, white, edged outwardly with red-brown and overlaid with brilliant silvery scales; second line from inner margin at two-thirds, oblique and straight to the third median, white internally, edged with red-brown and overlaid with silvery scales, retracted above the third median towards costa, and there only red-brown and silvery; a lustrous metallic marginal line starting on costa before apex, slightly interrupted just at apex and thrice interrupted above anal angle between the veins.

Hindwings: with the costal region broadly pale; the two lines produced across the wings, the first close to base, the second postmedian; marginal line uninterrupted from below apex; fringes of both wings concolorous.

Underside gilded yellowish; the apex of forewings broadly bronzy pinkish. Palpi yellow, tip of terminal joint dark; face and antennae yellow; collar and base of patagia metallic greenish white; rest of patagia yellow, with an orange band in middle ; thorax and abdomen yellow ; basal segment of abdomen metallic greenish white, edged with reddish brown, being a continuation of the first line of the wings.

Expanse of wings : $32 \mathrm{~mm}$.

Three $q q$ from Humboldt Bay, collected by Doherty in September and October 1892 .

An insect of very striking appearance, with a superficial resemblance to Plutodes. The inner margin of the hindwings is scantily developed; the $\delta$ will probably exhibit sexual distinctions.

\section{Eriopithex gen. nov.}

Distinguished from Chloroclystis, of which it is a development, by the antennae of the $\delta$, which have the basal joint swollen, the shaft thickened and flattened, and clothed above with thick downy hairs for four-fifths of its length.

Type: Eriopithex lanaris sp. nov. 


\section{Eriopithex lanaris sp. nov.}

Forewings: pale dull grey, the lines darker grey; three or four in the basal area; a thick dark line beyond one-third, angled below costa, then oblique inwards, with dark marks on veins; second line at two-thirds, oblique outwards, angled on vein 6 , and again on vein 4 , then oblique inwards, followed by whitish dots on veins and preceded by a dark shade which runs in along the veins; submarginal line fine and pale, preceded by a dark shade and a blotch opposite the cell; marginal line dark grey, interrupted at the veins; fringe concolorous.

Hindwings: whitish grey, with blackish cell-dot and postmedian line, the latter incurved opposite the cell. In both wings the paler interspaces between the lines are traversed by faint wavy darker lines.

Underside greyish white, with the outer line showing darker. Head, thorax, and abdomen cinereous.

Expanse of wings: $\delta, 16 \mathrm{~mm} . ;+1,14 \mathrm{~mm}$.

A pair from the Khasias.

\section{Micrulia gen. nov.}

A development of Chloroclystis; distinguished by the hindwings of the $\delta$, which are triangular in shape, with the hindmargin nearly straight; the inner margin puckered above, and bearing beneath from the anal angle to the median vein tufts of thick hair.

Type: Micrulia tencilinea sp. nov.

To this genus will belong also Chloroclystis emarginaria Hmpsn. and recensitaria Wlk.

\section{Micrulia tenuilinea sp. nov.}

Forewings: dark grey; first line beyond one-third, oblique outwards to the largish black discal spot, then sharply angled and oblique inwards, preceded by a darker grey shade; basal area with two or three obscure dark lines; second line at two-thirds, curved outwards below costa, regularly waved and curved to inner margin at two-thirds, pale, followed by a fine dark line and preceded by a thick dark grey shade; submarginal line fine and pale, regularly waved, preceded by a dark grey shade; marginal area dark grey; all the lines start from dark costal blotches; marginal line blackish, interrupted at the ends of the veins by small pale dots; fringe ochreous grey, rather glossy.

Hindwings: the same, with a dark diffuse blotch in disc before the postmedian line.

Underside whitish, with the cell-dots and curved fasciae dull dark grey; tufts of hindwing black, ochreous at their base. Face, palpi, and vertex ochreous; thorax and abdomen grey.

Expanse of wings: $18 \mathrm{~mm}$.

Two of of from the Khasias.

The veins are often marked with black dashes.

\section{Opistheploce gen. nov.}

8. Forewings: very broad; costa nearly straight; apex blunt; hindmargin long and strongly curved; inner margin convex beyond the middle. 
Hindwings: small, narrow, puckered below towards hindmargin, and with the hindmargin convolute and folded over above,

Frontal tuft acute and prominent; palpi porrect, twice as long as head, rough ; hind tibiae with three very long spurs, the single one from near the base.

Neuration: as in Tephroclystia.

Type: Opistheploce cinerea sp. nov.

Certainly related to Walker's genus Mariaba, but the hindwings are not produced to a point at apex.

\section{Opistheploce cinerea sp. nov.}

Forewings: dingy grey, with darker lines; one near base, indistinct; the second central, passing over the large black cell-spot; the third postmedian, broad, with the outer edge waved; submarginal broad, curved and waved, followed by a fine pale waved line and preceded by a pale fascia with a dark line along its centre; hindmargin dark, with a dark marginal line, interrupted by minute pale dots on veins; fringe grey, with paler base.

Hindwings: dull ochreous grey, without markings, becoming darker along hindmargin.

Underside whitish, with the bands all darker and clearer. Head, thorax, and abdomen grey.

Expanse of wings : $18 \mathrm{~mm}$.

One $\delta$ from Batchian, March 1892 (W. Doherty).

\section{Subfamily DEILINIINAE.}

\section{Aplochlora subflava sp. nov.}

Like Aplochlora vivilaca Wlk., but smaller, paler green above, and with the underside of both wings dull yellow.

Expanse of wings : $30 \mathrm{~mm}$.

One $q$ from Humboldt Bay, New Guinea, October 1892, taken by Doherty.

\section{Bapta lucens sp. nov.}

Forewings: silvery white, dusted with fine olive atoms; costa bright yellow, broader towards apex; no inner line; exterior line at three-fourths, nearly parallel to hindmargin, yellowish, with olive scales; discal spot round, olive, edged with yellowish; fringe ochreous, greyer towards the apices.

Hindwings: the same, the discal spot hardly marked.

Palpi rufous; face dark red-brown; thorax and abdomen white, with fine olive atoms. Underside wholly pure white; the fringes white.

Expanse of wings : $36 \mathrm{~mm}$.

One \& from West Java.

\section{Borbacha lineata sp. nov.}

Forewings: sandy ochreous, speckled and marked with dull ferruginous; the costa with smaller, more reddish atoms; no distinct inner line; exterior line at threefourths, diffuse and partially double, not reaching costa or inner margin, irregularly 
waved and dentate, accompanied by dark dots on veins, which are produced in places towards hindmargin as streaks on the veins; submarginal line near hindmargin, running into apex; a double straight oblique line mixed with greyish scales from inner margin at one-third to middle of hindmargin, running out into the fringe as a dark spot; a row of blackish marginal spots ; fringe pale ochreous ; cell-spot small, dark.

Hindwings: with the oblique double line of forewings continued across the basal region; an indistinct double postmedian line, becoming single and denticulate towards costa; followed by another line, distinct and denticulate also only towards costa ; submarginal line straight and fine, from just above anal angle towards apex, before which it is eurved to costa ; cell-spot small, dark; fringe ochreous, with a dark spot at end of third median, as in forewings.

Palpi ochreous, blackish above; face ochreous, with a dull red bar at top; vertex pale ochreous, with a very fine red line across middle; thorax and abdomen ochreous. Underside very pale ochreous, with the markings as on upperside but dull brownish.

Expanse of wings: $38 \mathrm{~mm}$.

Two $\delta$ from West Java (type), and one $\delta$ from Nias.

Distinguished from B. pardaria Guen., not only by the different coloration and markings, but by the outline of the wings: in pardaria the hindmargin of both wings is simply rounded; in lineata the forewings are bluntly elbowed at the third median; the hindwings are produced to slight points at veins 4,6 , and 7 , being slightly excised between each, and straight from the end of 4 to anal angle.

\section{Parasynegia borbachodes sp. nov.}

Forewings: pale yellowish, with coarse spots of dull blood-red; the markings formed of dull purplish grey red-edged blotches; basal line obscure, but forming a squarish blotch in cell, and another obliquely below it basewards underneath the median vein; cell-spot dark brown; central shade entire, angled below costa, its inner edge regularly waved, its outer edge bluntly and irregularly toothed; outer and submarginal lines consisting of blotches, visible only at costa and opposite cell, and here confusedly running into each other and joined to the central shade; fringe yellowish, with purple-grey spots at end of veins.

Hindwings: with the blood-red spots clearer; a grey basal mark; a grey, largely lunate, central fascia, double on inner margin; a broad grey submarginal streak from inner margin above anal angle to apex, swollen in centre and there followed by a blotch which touches the margin; cell-spot brightly black.

Underside dull straw-colour, with the markings dull grey. Face and palpi yellowish below, ferruginous above; fillet yellow ; thorax and abdomen yellow, dotted with blood-red; the latter with a dark grey band on basal segment.

Expanse of wings : $30 \mathrm{~mm}$.

One $\&$ from West Java.

Akin to P. erythra Hmpsn. and suffusa Warr.

The antennae are distinctly serrate. The markings bear a strong resemblance to those of Borbacha.

\section{Parasynegia nigrifasciata sp. nov.}

Forewings: straw-colour, suffused with fulvous, and with a few blackish atoms; costa with strong black striae; a black spot on costa at base; a square black spot on costa at one-fourth and one on inner margin at one-third denote the first line; cell- 
spot round and large, black, connected above with a black costal spot; a broad black fascia from costa at three-fourths, ending at vein 2 ; its inner edge sinuous, with a fulvous margin and line of dark dots on veins; its outer edge strongly angled at vein 4 , then excised, margined with paler straw-colour; a black blotch from its angle to hindmargin; fringe straw-colour.

Hindwings: with two black spots on inner margin, an indistinct antemedian line, small cell-spot, and blotched submarginal fascia, which is narrowed from middle to anal angle.

Underside similar, but with no fulvous suffusion. Face and palpi straw-colour; palpi black on sides; head and thorax fulvous-tinged; abdomen straw-colour, with black dorsal stripe; metathoracic tuft black.

Expanse of wings: $38 \mathrm{~mm}$.

One $\delta$ from South Java, 1891, 1500 feet (Fruhstorfer).

Plectoneura gen. nov.

Fonewings: with costa slightly curved; apex produced, but blunt; hindmargin obliquely curved.

Hindwings : with the inner margin lengthened, the hindmargin bluntly elbowed at vein 4 , straight or nearly so on either side.

Antennae of $\delta$ subdentate, ciliated; palpi upturned and erect in front of face, third joint small ; tongue present ; hind tibiae not thickened, with four spurs ; forewings without fovea; hindwings with frenulum.

Neuration: forewings, cell half as long as wing; discocellular straight; first median at two-thirds, second and third from lower angle of cell ; lower radial from middle of discocellular, upper from upper angle; all five subcostals stalked from some way before end ; the costal forked towards costa, and the first subcostal anastomosing with the lower fork; the submedian thickened and strongly sinuous near base. Hindwings with first subcostal from considerably before top end of cell.

Type: Plectoneura albida sp. nov.

This genus is related to Leucetciera, but is sufficiently distinguished by the neuration of the forewings.

\section{Plectoneura albida sp. nov.}

Forewings : milk-white, sparsely sprinkled with black scales; costa ochreous ; lines faintly ochreous ; first at one-third, angled below costa ; second at four-fifths, parallel to hindmargin, regularly dentate; cell-spot black, ringed with ochreous; a narrow grey marginal blotch from below apex to middle of margin ; fringe greyish ochreous.

Hindwings: similar, without the first line.

Palpi and face deep red-brown ; collar dull greyish ; thorax and abdomen white, fuscous-speckled. Underside white, suffused with reddish yellow.

Expanse of wings : $32 \mathrm{~mm}$.

One of from Moroka, British New Guinea.

\section{Subfamily ABRAXINAE.}

\section{Abraxas nigriclathrata sp. nov.}

Forewings: white; the costa black, broadening to the apex; a black spot at base and a smaller one at edge of fovea ; first line from costa at one-third to inner margin 
at one-fifth, blackish, composed of confused striae; a blackish blotch in middle of inner margin, with a crescentic blotch above it, almost connected with a short projection from the costal streak; outer line at three-fourths, curved and wavy, broad where it leaves the costal streak, narrow below middle, preceded by a row of black spots on veins, and followed by a series of wedge-shaped and lunular white marks before the broad black hindmargin; fringe black.

Hindwings: white, with a black basal streak; an irregularly curved and wavy outer line, preceded by small vein-dots, that on the inner margin expanded into a blotch; hindmargin narrowly black, touching a series of elongated blotches on the veins which do not quite reach the outer line.

Underside exactly the same. Palpi black; face yellow, with a black central bar ; vertex yellow; thorax and abdomen yellow, spotted with black.

Expanse of wings: $52 \mathrm{~mm}$.

One ơ from Sukabumi, West Java, 1893 (2000 feet).

\section{Percnia albinigrata sp. nov.}

Forewings: white, tinged with grey, with six rows of black spots ; first basal, of two spots; second subbasal, curved, of four spots, on subcostal, median, submedian, and inner margin respectively; third antemedian, straight, of three double spots, first on costa and subcostal vein, second on either side of the median, third on submedian and inner margin; fourth row postmedian, outcurved round cell, the eurved part formed of six irregular-sized and confluent spots, with three spots below, one on the first median nervule and two confluent on submedian and inner margin; fifth row submarginal, of ten spots between the veins, the third and sixth small; sixth row marginal, between the veins, also of ten spots, large and round, except the apical and anal angle spots, which are flattened; fringe white; a large discal blotch.

Hindwings: with four rows; first antemedian, of three spots; second median, of seven spots, the second and third and the fourth and fifth confluent; third row submarginal, of seven small spots; fourth marginal, of eight spots; a large discal spot.

Underside like upper, but with the costal and hindmargins of forewings smoky grey ; this tint is also visible on the upperside, but not so strikingly. Face, palpi, and antennae black; mouth parts whitish; collar, shoulders, patagia, thorax, and abdomen all white, with pairs of black spots.

Expanse of wings: $65 \mathrm{~mm}$.

One $q$ from Niphon, Japan.

\section{Potera flavimacula sp. nov.}

Forewings: with basal and marginal areas brown-black, central area white; the black at the base extends to beyond middle of costa and nearly to middle of inner margin, its edge sinuous ; its outer edge starts from three-fourths of costa, runs first obliquely outward, then vertical, again obliquely inward, and vertical to inner margin at three-fourths on one wing; on the other obliquely inwards to inner margin at twothirds, so that the white fasciae of the two wings do not correspond in shape; the dark margin contains a hook-shaped yellow spot below apex with a small yellow dot below it and two diamond-shaped yellow spots above anal angle; these spots lie in the 
intervals between the veins, and two very minute dots can be detected between the apical and anal spots; fringe black; an orange dot at base and one beyond it below the median.

Hindwings: with basal one-third black, and a black uniformly broad marginal fascia, containing three yellow diamond-shaped spots, one towards apex, the other two below the median; the inner edge of the marginal fascia on both wings is deeper black, edged by a faintly paler shade before the row of spots; the basal and marginal black areas are united along the costa of each wing, more broadly in the hindwing than in the forewing.

Underside the same. Face yellow; vertex, shoulders, and base of patagia orange; thorax and first segment of abdomen black; rest of abdomen orange, with broad black dorsal triangles on each segment and a pair of black spots at the sides; a series of lateral spots, and a double series of spots beneath; legs with the femora orange spotted with black, tibiae and tarsi black; tongue and palpi yellow; tips of palpi and antennae black.

Expanse of wings : $60 \mathrm{~mm}$.

One \& from Cedar Bay, south of Cooktown, Queensland (A. S. Meek).

\section{Potera intervacuata sp. nov.}

Forewings: white, the base black along costa, median and submedian veins; a strongly curved thick black line at one-fourth, with a more irregular abbreviated curved line inside it; costa beyond first line broadly black, containing a small white spot touching first line, united with a square black cell-spot, from the lower end of which a thick black streak runs horizontally to the hindmargin; an exterior curved line of contiguous blotches, its outward edge dentated; hindmargin broadly and irregularly black, thickened at apex, middle, and anal angle.

Hindwings: the same, with a faint basal line; the postmedian more regular, with a blotch running from it to hindmargin opposite the cell; margin much narrower than in forewings.

Underside the same; hindwings with a black subbasal costal blotch. Face and collar pale yellow; front of thorax with a Llack bar; thorax and abdomen yellow, with black spots.

Expanse of wings : $50 \mathrm{~mm}$.

One $\delta$ from Mt. Mulu, North Borneo, 1000-4000 feet (Hose).

\section{SubFamily BRACCINAE.}

\section{Bursada bistrigata sp. nov.}

Forewings: deep brown-black, with two orange patches from the costa; the first small, at one-fourth, oblique and reaching just below the median; in the $\delta$ it starts from below the costa; in the $q$ it is decidedly broader and paler, and starts from the costa; the second patch, also oblique, at two-thirds, somewhat bent, is directed towards the anal angle, but only reaches beyond the median, where it is swollen outwardly towards hindmargin; this, which is orange in the $\delta$, is yellow in the $q$, and twice as large, reaching nearly to the hindmargin; the costa of forewing is sinuous, being shouldered at the base, the shoulder containing a hyaline blotch, larger than that in B. hyaloplaga, and present in the $q$ as well as in the $\delta$. 
Hindwings: orange, with a black border; on the inner margin this border runs up to the base and has a projection towards costa above the anal angle; the margin between veins 2 and 4 opposite the sinus is very narrow, the yellow ground in the $q$ almost touching the margin, while at the apex it is much broader, with two curved projections; fringe of hindwings black; of forewings black, with a white patch above anal angle and below apex, but much less strongly so than in hyaloplaga Warr.

Underside like upper; in the forewings the inner blotch runs, as above, from the costa, while in hyaloplaga it starts from the base. Head, thorax, and abdomen all black.

Expanse of wings: $\delta, 24 \mathrm{~mm}$; ; $\uparrow, 26 \mathrm{~mm}$.

Two $\delta \delta$, one + , from the Tenimber Islands, July 1892 (W. Doherty).

Nearly related to B. hyaloplaga from Humboldt Bay, New Guinea, but certainly distinct.

\section{Bursada hyaloplaga sp. nov.}

8. Forewings: deep brown-black, the costa shouldered at base and with a semihyaline blotch within it; a small fulvous blotch in cell, more or less obseured by dark scaling; an oblique oval yellowish blotch from below two-thirds of costa towards anal angle, shaped as in synestia Meyr., but without any red tinge; fringe dark, with pale patch above middle and anal angle.

Hindwings: yellow, with all the margins black; a small black tooth on costal margin facing that above anal angle on inner margin; the yellow without any red tinge; fringe wholly black.

Underside the same, but the spot in cell of forewing clear yellow and narrowed to the base. Face, palpi, head, thorax, and abdomen all blackish; sides of abdomen yellow.

Expanse of wings : $28-32 \mathrm{~mm}$.

In some numbers from Humboldt Bay, New Guinea, October 1892 (W. Doherty).

Distinguished from both fulvimacula Warr. and synestia Meyr. by the absence of the red tint, and by the semihyaline space at base of costa in the $\delta$.

In a few cases the oblique blotch (which is considerably variable in shape and size) touches the costa ; and in one example, where this blotch is more than usually developed, the obsolete basal patch has a yellow spot on costa above it.

\section{Bursada oppositata sp. nov.}

Bursada salamandra Kirsch, Mitth. Diesd. Mus. I. (1877), p. 133 (part), nec figure.

Kirsch appears to have confused two species: his description and figure apply exactly to Boisduval's xanthomelas; but he adds that some examples showed a tendency to throw off a black streak from the anal angle. I have before me both forms from Humboldt Bay; in this latter form, for which I propose the name oppositata, not only is the protuberance from the anal angle prominent, but there is a corresponding, though smaller, prominence from the costal black margin opposite. In the forewings the yellow basal blotch is more interrupted by the protrusion into it of the black inner margin, this protrusion having generally an irregular triangular form. 
Two $\delta \delta$, one $q$, from Humboldt Bay, October 1892 (W. Doherty).

In Walker's B. quadripartita from Aru (= salamandra Pagenst., nec Kirsch), which much resembles the present insect, the projection from anal angle lies higher up the inner margin, and runs to within the middle of costa instead of towards its apex; and in the forewings the outer yellow spot has a pointed lower end, while in oppositata the end is always bluntly rounded.

\section{Bursada pyrifera sp. nov.}

Like $B$. xanthomelas Boisd., but larger; the pear-shaped yellow basal bloteh broader, its lower edge straight; the central black fascia, which varies in width, not so oblique; the apical yellow blotch larger and nearer hindmargin, so that the black marginal border is narrower.

Hindwings: yellow, with the black marginal border narrower.

Underside like upper. Head, thorax, and abdomen all black.

Expanse of wings : $30-34 \mathrm{~mm}$.

Three $\delta \delta$ from Korrido, Dutch New Guinea (W. Doherty).

\section{Craspedosis (?) bicolorata sp. nov.}

Forewings: velvety brown, with a broad whitish fascia from just beyond middle of costa towards anal angle, before which it stops, but throws off a dull pale line to inner margin; the inner edge of the white fascia is straight, the outer irregularly wavy.

Hindwings: brown, with two large contiguous yellow lunules from third median to hindmargin before anal angle; fringe of both wings brown.

Underside like upper, the yellow lunules of hindwings more developed. Head, thorax, and abdomen all brown, as well as the legs and underside, except the last four segments of abdomen, which are yellow with brown rings.

Expanse of wings: $58 \mathrm{~mm}$.

One $q$ from Amboina, August 1892 (W. Doherty).

In the forewings the first and second subcostals are stalked, the second becoming coincident with third and fourth.

\section{Craspedosis leucosticta sp. nov.}

Forewings : dull blackish slate-colour; a straight white streak running obliquely from subcostal vein to first median, bordering the discocellular, varying in shape and development; above the anal angle is a faint trace of a pale grey submarginal line.

Hindwings: slate-colour, with a broad white central space, not touching the costa, the inner edge of which is straight and the outer sinuous, almost angled at vein 3 ; along the middle of the dark outer margin runs a curved dull slate-coloured fascia ; fringes of both wings concolorous.

Underside like upper, but blacker, with no trace of submarginal band in either wing. Head, thorax, and first two segments of abdomen slate-colour; rest of abdomen yellow.

Expanse of wings: $54 \mathrm{~mm}$.

In great abundance from Cedar Bay, south of Cooktown, Queensland. 


\section{Craspedosis ovalis sp. nov.}

Like $C$. semiplaga Warr., but in the forewings, instead of the narrow sinuous white fascia, is an oblique oval white blotch. Hindwings with the base black; the inner margin narrowly, the hindmargin very broadly, black. Abdomen with first three segments orange above; head wholly black.

Expanse of wings: $42 \mathrm{~mm}$.

Two $\delta$ ठ from Humboldt Bay, New Guinea, October 1892 (W. Doherty).

\section{Craspedosis schistacina sp. nov.}

Forewings: black, with a bluish slate-coloured streak from base to middle of cell ; an oblique oval white blotch from near middle of costa towards anal angle, its edges marked with pale slate-colour; a similar-coloured submarginal line from anal angle diverging from hindmargin and ending diffusely at vein 6 .

Hindwings: with base narrowly black, edged with slate-colour; a broad black marginal border, with a bluish slate-coloured distinct line through the middle; central area white, with its edges slate-colour.

Underside without the submarginal lines. Head, thorax, and first two segments of abdomen blackish varied with slate-colour; last five segments of abdomen yellow.

Expanse of wings: $52 \mathrm{~mm}$.

One $\delta$ from Simbang, near Finschhafen, German New Guinea.

Extremely close to $C$. aruensis Pagenst., but with the white blotch straight, not rounded, above.

\section{Craspedosis semilugens sp. nov.}

Forewings: dark smoky slate-colour; a curved slightly paler slate-coloured fascia close to base, with darker margins; from centre of costa, but not quite touching it, a broad white fascia runs to inner margin before anal angle, its inner edge quite straight, its outer slightly curved and waved.

Hindwings: bluish slate-colour, with a paler curved line, inwardly darkmargined, from three-fourths of costa to inner margin above anal angle; fringe concolorous.

Underside of both wings paler, the markings as above. Head, thorax, and abdomen all pale slate-colour.

Expanse of wings : $48 \mathrm{~mm}$.

Both sexes from Humboldt Bay, New Guinea, October 1892 (W. Doherty).

\section{Stenocharta gen. nov.}

Forewings : narrow, elongate; costa straight, with a slight shoulder at base, and curved before apex ; hindmargin very obliquely curved.

Hindwings : narrow; the apex slightly produced; hindmargin and inner margin curving into each other.

Abdomen of $\delta$ very long and slender; the anal tufts exaggerated. Palpi with the second joint long and stout, suberect, the third short. Antennae of $\delta$ simple, lamellate, thickened beyond middle and ending in a point, as in Cystidia Hüb. Hind tibiae thickened, with a pencil of hairs and four spurs. 
Neuration: forewings, cell quite half as long as wing; discocellular angulated, the lower arm oblique; first median at four-fifths, second just before end of cell; lower radial slightly above centre of discocellulars, upper from top end of cell; last four subcostals stalked, first anastomosing with costal, second with first. Hindwings with costal abruptly curved upwards at middle of cell ; the first subcostal also similarly curved before the end of cell.

Type: Stenocharta quadriplaga Wlk. (Nyctemera).

\section{SubFamily SELIDOSEMINAE. \\ 1}

165. Petelia (?) inconspicua sp. nov.

Forewings: dull reddish brown, much sprinkled and suffused with fuscous, the base, a broad diffuse fascia in middle, and the marginal area being darker and leaving two obscurely paler spaces between them; the inner edge of the marginal area is fairly distinct and obtusely bent at middle; submarginal line indistinctly indicated by slight patches of whitish scales between the veins; fringe concolorous, with a row of minute dark dots at the ends of the veins.

Hindwings: the same.

Underside pale ochreous grey, dusted with fuscous; a narrow central and broad dark marginal fascia. Head, thorax, and abdomen reddish grey-brown; fillet and antennae whitish.

Expanse of wings: $48 \mathrm{~mm}$.

Two $q$ \& from Geraldton. Cairns, Queensland (A. S. Meek).

In the forewings vein 11 anastomoses strongly with 12 , and then less strongly with the stalk of $8,9,10$.

\section{SubFamily BISTONINAE.}

\section{Blepharoctenucha albescens sp. nor.}

Forewings: white, irrorated with fuscous grey ; the lines oblique, blackish; first from costa at one-third, bent on subcostal, then obliquely curved to inner margin close to base, preceded by a similarly curved fascia of grey scales; a diffuse central shade, broad above, narrower and darker towards inner margin; the discocellular mark an irregular white lunule edged with dark; outer line from costa at threefourths, wavy and vertical to the middle, then sinuous and oblique to inner margin beyond the middle, followed by a grey-scaled fascia; submarginal line pale, obscure, with a fascia of grey scales on each side, which is distinct only towards costa ; a row of black marginal dashes between the veins; fringe white.

Hindwings: the same, with the antemedian line straight and thick.

Underside white; the cell-spots and marginal spots of both wings black; apex of forewings with a subapical costal blackish blotch curved to the hindmargin. Face and palpi whitish, face sometimes with dark streaks; thorax and abdomen white, irrorated with fuscous; shoulders and patagia with a dark bar towards apex ; segments of abdomen dark.

Expanse of wings: $\delta, 52 \mathrm{~mm}$;, $65 \mathrm{~mm}$.

One $\delta$, two $q+$, from South Java, 1891, 1500 feet (Fruhstorfer). 
The forewings are elongate, with very oblique hindmargin; the antennae of the $\delta$ are ciliated, the cilia rising in short tufts from the shaft; in the type of the genus, B. virescens Butler, the cilia are strongly fasciculated.

\section{Buzura pustulata sp. nov.}

Forewings: ochreous, coarsely irrorated with black scales; first line black, curved, from one-fourth of costa to near base of inner margin, preceded by a yellow tinge and a black line from median to submedian; a black spot on costa before middle, from which an indistinct curved yellow central shade runs to middle of inner margin ; cell-spot dull grey; outer line at three-fourths, black and sinuous, forming a blunt angulation outwards opposite cell and on submedian fold and a strong sinus inwards between, followed by a broad yellowish shade containing patches of black scales beyond the line, those opposite the cell and below vein 4 large and conspicuous; fringe yellow.

Hindwings: the same, without first line; the central yellow shade marked with black on inner margin.

Underside yellower, with fuscous irroration; the cell-spots black, that on the forewings large. Palpi and face yellowish below, black above; vertex yellowish; thorax and abdomen yellowish ochreous, irrorated with black scales; abdomen with a black band at base.

Expanse of wings: $64 \mathrm{~mm}$.

One $\delta$ from Perak, Malay Peninsula.

\section{Cusiala fessa sp. nov.}

Forewings: bone-colour, with ferruginous and blackish dusting; first line at one-fourth, diffuse, consisting of black and ferruginous scales; an indistinct cloudy central shade; exterior line from three-fourths of costa to inner margin before anal angle, irregularly angled and waved; followed by a ferruginous fascia, separated by a pale submarginal line from the ferruginous hindmargin.

Hindwings: with a curved diffuse central line; exterior line straight from above anal angle to middle, then slightly bent and angled; followed by ferruginous scales traversed by the pale submarginal line.

Underside pale, without dusting; the cell-spots of both wings large and rusty. Face ochreous, with a broad brown central bar ; antennae ferruginous ; vertex, thorax, and abdomen bone-colour.

Expanse of wings: $52 \mathrm{~mm}$.

One $\delta$ from Adonara, November 1891 (W. Doherty).

\section{Cusiala semialbida sp. nov.}

Allied to $C$. semiumbrata Warr., from Fergusson Island, with which it agrees in the markings and coloration of the forewings, except that the cell-mark is a distinct black lunule, not ocelloid.

The hindwings are entirely white, coarsely and sparsely speckled with fuscous; the outer line fuscous, forming a very strong sinus inwards from inner margin to beyond cell, where it is acutely angled; in the sinus formed by this line is a fuscous somewhat annular blotch; submarginal line obscure, fuscous, marked only towards inner margin. 
Vertex, collar, and thorax whiter than in semiumbrata; the shoulders and patagia tipped with rufous.

Expanse of wings: $52 \mathrm{~mm}$.

One $\delta$ from Batchian, March 1892 (W. Doherty).

\section{Subfamly ASCOTINAE.}

\section{Carecomotis gen. nov.}

Distinguished from Chogada Noore by the antennae of the $q$, which are strongly pectinated for three-fifths, as in the $\delta$; but whereas the pectinations in the $\delta$ are strongly pubescent, those of the $q$ are very slightly so.

Type: Carecomotis perfumosa sp. nov.

\section{Carecomotis perfumosa sp. nov.}

Forewings: pale grey, slightly tinged in parts and especially along the veins with pale olive-green; the markings purplish black; first line at one-third, wavy, preceded by a similar but less distinct one; the extreme base black, and a black spot below the median; cell-spot of leaden-grey scales, surrounded by blackish scaling and connected above with a black costal spot; exterior line from costa beyond two-thirds to inner margin at two-thirds, wavy and denticulated, followed immediately by a similar but fainter line, consisting of connected lunules; subterminal line formed by a series of broad wedge-shaped blotches; a submarginal line of smaller blotches connected laterally with a similar marginal line; marginal area beyond outer line tinged more or less with pale slate-colour, except a small pale spot on hindmargin below middle; fringe pale grey, with darker spots at end of veins; from the outer side of cell-spot a wavy central line runs to inner margin, nearly touching the outer line.

Hindwings: like forewings, but the exterior line more excurved in middle.

Underside whitish, suffused with smoky grey; the cell-spots large and black; a broad diffusely edged black marginal band, containing a small pale spot on hindmargin of both wings below the middle and at apex of forewings. Palpi dark grey ; face, vertex, and patagia dull olive-yellow ; thorax and abdomen bluish grey, the latter with a double row of black spots down the back and with black lateral markings; the first segment with a double yellowish grey tuft.

The form above described is the palest. Equally common is a very dark form in which the ground-colour is dull greenish grey, suffused and speckled with blackish and with all the markings darker, the basal area, the hindmarginal pale spot, and a blotch on inner margin beyond outer line being tinged with reddish. Head, thorax, and abdomen dark olive-grey, with markings obscure. Underside much darker than in the type.

Expanse of wings : $36-40 \mathrm{~mm}$.

Three $\delta$, two $q f$, from Cedar Bay, south of Cooktown, Queensland.

\section{Catoria camelaria carbonata subsp. nov.}

Differs from the type-form camelaria Guen. in the markings of the underside. Instead of a smoky black marginal fascia, there is a subapical blotch, coal-black, as 
is the discal spot; the blotch below and that at the apex of hindwings is of the usual smoky fuscous tint. Both sexes from Lifu.

Examples from Dili and Oinainisa, Timor, agree entirely with the typical form from Australia.

\section{Chogada epistictis Meyr. ab. albibasis nov}

Forewings: with the central line thick and black, twice angulated; the basal line faint; basal area and marginal half beyond central line rufous grey, dusted with coarse blackish atoms, the outer line being fine and indistinct; space between basal and central lines white.

Hindwings: with base white to the thick black basal line; all the rest of the wing dull rufous grey with black atoms, the exterior line of forewings becoming central and blackish.

Underside wholly dull smoky cinereous.

One $\delta$ from Biak, Geelvink Bay, New Guinea, collected by Doherty. A very striking aberration.

\section{Dryocoetis cineracea Moore ab. subalbida nov.}

Marked above exactly as typical cineracea ; but the underside, instead of being dark smoky cinereous, is nearly white, so that the upperside appears paler; and in the hindwings the space between the antemedian and postmedian lines is largely white.

Several from the Khasias, taken at the same time as the ordinary form.

\section{Ectropis dentilineata Moore ab. pulverosa nov.}

Forervings: dirty grey, confusedly irrorated with fuscous olive, and having all the markings more or less obscured; the base and costa are especially darker.

Hindwings: rather paler. paler.

Underside dull whitish. Head and thorax dull grey; the abdomen a little

Apparently common in the Kulu district.

Besides differing in coloration, this form is distinguished from the type by the more elongate forewings.

\section{Lassaba indentata sp. nov.}

Very much like $L$. albidaria Wlk., but smaller, less coarsely irrorated and with the lines finer and less evident; the exterior line not outcurved round cell; the submarginal line edged internally by an olive-grey diffuse fascia, abruptly bent in above third median towards the dark mark in the exterior line and darker beyond it, but not forming a second dark line as in albidaria; marginal area from apex to the bend suffused with grey and with a darker grey blotch before the bend, the marginal area within the sinus being conspicuously pale.

Underside of forewing with a blackish apical blotch beyond submarginal line as far as third median, including a square white spot at the apex; a slight grey submarginal continuous fascia on both wings.

One $\delta$ from South Java, 1891, 1500 feet (Fruhstorfer). 


\section{Myrioblephara picta sp. nov.}

Forewings: pale green, suffused with darker green and varied in places with ochreous, and marked with blackish transverse striae; basal area varied with ochreous and blackish scales, then a pale fascia of ground-colour, followed by an antemedian curved fascia of blackish and ochreous scales; central space pale green, containing a small dark cell-spot connected with a darker costal blotch, which is produced as a central shade to inner margin; outer line just beyond middle, blackish and sinuous, to inner margin beyond middle, forming a short but decided prominence opposite the cell; space beyond varied with darker green and ochreous, traversed by a distinct, hardly waved, pale ochreous submarginal line; the veins beyond outer line yellowish; a row of dark marginal lunules; fringe pale ochreous grey, its basal half somewhat darker, with blackish streaks throughout from the ends of the veins.

Hindwings: paler towards base, with a broad submarginal fuscous band, the margin itself dull green.

Underside ochreous grey, with a broad submarginal grey band on both wings. Face, palpi, and thorax ochreous; abdomen greyish.

Expanse of wings: $26 \mathrm{~mm}$.

One $q$ from South Java, 1891, 1500 feet (Fruhstorfer).

In the forewings veins 10 and 11 are coincident and anastomose for a considerable distance with the costal.

Although $I$ have not seen a $\delta$, the resemblance of the single $q$ to the Indian species of the genus, as well as the neuration, induces me to refer it without much misgiving to Myrioblephara.

\section{Pachyplocia gen. nov.}

Forewings: with costa straight; apex rounded; hindmargin strongly rounded, slightly crenulate.

Hindwings: in $q$ with hindmargin crenulate in upper half only, straight towards anal angle, which is squared; in the $\delta$ strongly rounded throughout, with the inner margin greatly expanded so as to form a swollen lobe, generally folded over above, and with a tuft of long hairs from the base of wing.

Fovea of forewings large and prominent. Palpi stout, upcurved in front of face; antennae of $\delta$ with short even pectinations, of $q$ simple; hind tibiae of $\delta$ somewhat thickened, with four spurs.

Neuration: forewings, cell more than half as long as wing; first two subcostals coincident; last three stalked, from before end of cell ; radials normal. Hindwings with cell two-thirds of wing, the discocellular oblique; the costal vein approximated to subcostal half-way along cell, then abruptly curved away.

Type: Pachyplocia griseata sp. nov.

\section{Pachyplocia griseata sp. nov.}

Forewings: fuscous grey, rufous-tinged and speckled with dark atoms; first line black, from costa at one-third, strongly curved to inner margin close to base, preceded by a dark cloud; outer line from costa at three-fourths to middle of inner margin, sinuous; submarginal line oblique, irregularly dentate, the space between it and outer line darker; the submarginal line is edged with paler; fringe concolorous, with 
dark marginal line at base; cell-spot dark, a central line sometimes visible nearly touching it.

Hindwings: with darker antemedian, central, and postmedian lines, the last most distinct.

Underside dull grey, with the margins darker. Face and palpi dark grey ; thorax and abdomen paler, the latter with darker segmental rings and a black ring at base.

Expanse of wings : $26 \mathrm{~mm}$.

Both sexes from Cedar Bay, south of Cooktown, Queensland.

\section{Poecilalcis semiclarata Wlk. ab. albilinea nov.}

Differs from the type in having a small diffused whitish blotch occupying the subcostal angle of the outer line; a similar whitish blotch at middle of hindmargin instead of the larger ochreous one; and the submarginal line fine, waved, and whitish throughout.

Four $q q$ only, from Darjiling (Pilcher leg.).

\section{Poecilalcis semiclarata Wlk, ab. fasciata nov.}

Ground-colour of forewings brownish ochreous with a rufous tinge; the inner line immediately preceded and the outer line followed by a dark brown-black shade; the submarginal line scarcely paler and indistinct; the blotch at middle of hindmargin slightly enlarged and without fuscous striation.

Four $\delta$ o from Darjiling (Pileher leg.).

\section{Polylophodes gen. nov.}

8. Forewings: elongate; the costa shouldered and hairy at base, faintly insinuate beyond, and faintly curved to apex, which is blunt; hindmargin very obliquely curved; inner margin convex.

Hindwings : forming an equilateral triangle, the apical and anal angles broadly and bluntly rounded; the hindmargin slightly sinuate inwards in middle; the region of the anal angle beneath covered with a thick mealy efflorescence, mixed with long hairs along the hindmargin.

Abdomen with tufts of long silky hair from the sides of second and following segments; vertex with projecting scales; antennae pectinated, the pectinations stiff and ciliated; palpi short, hairy, decumbent; third joint minute; tongue well developed; frenulum present; forewings with a strong somewhat puckered fovea; hind tibiae broken; mid tibiae with a pair of long spurs clothed with hair.

Neuration: forewings, cell not quite half the length of wing; discocellular vertical ; first median at two-thirds, second and third from end of cell ; lower radial from centre of discocellular, upper from top angle of cell ; last three subcostals stalked from a little before end; first and second coincident, anastomosing with costal above origin of fifth. Hindwings with cell quite half the length of wing; discocellular with lower arm oblique; first median at two-thirds; second considerably before lower angle; costal approximated to subcostal for half the length of cell; first subcostal nervule considerably before upper angle.

Type: Polylophodes triangularis sp. nov.

A genus of which the typical species is abnormal both in structure and appearance; it should probably be placed near Myrioblephara Warr. 


\section{Polylophodes triangularis sp. nov.}

Forewings: pale green, suffused and irrorated with darker olive-green and fuscous; costa dotted with dark green and fuscous; first line at one-third, wavy and dark, starting from a larger costal spot; second line at two-thirds, dark and wavy, from a dark costal spot, incurved below middle, then outeurved to inner margin at two-thirds; the area between the two lines paler than rest of wing; cell-spot dark green, with a large costal blotch above it; submarginal line very pale greenish, distinct and denticulate below costa, where it is preceded by a dark olive-green patch; indistinct below and followed by two dark patches, one opposite the cell, the other half-way between first and anal angle; a row of dark green contiguous triangles along hindmargin; fringe pale greenish ochreous, with a darker central line, and strongly mottled with blackish opposite the veins.

Hindwings: with basal half ochreous white; an oblique pale greenish shade before middle, becoming dark green and distinct only on inner margin, where it is broad and edged outwardly with blackish; a wavy fuscous submarginal line, parallel to hindmargin, beyond which the margin is dull greenish fuscous in the costal half and olive-green mixed with dark fuscous and rufous towards anal angle, where a denticulate line is visible close to margin ; fringe olive-green, varied with fuscous; fringe of inner margin white.

Face, palpi, and thorax olive-green, speckled with darker; abdomen ochreous and olive-green; the lateral tufts pale olive. Underside ochreous white for two-thirds; this space edged by a bent dark line, followed by a dark shade and pale fuscous marginal area; costa dotted and spotted with fuscous; hindwings the same: the efflorescence at anal angle pale ochreous, yellower above.

Expanse of wings : $30 \mathrm{~mm}$.

One $\delta$ from Bandong, Java.

\section{Pseudocoremia flava sp. nov.}

Forewings: pale yellow, the costa and inner margin speckled with fuscous; a brown hourglass-shaped blotch on middle of costa extending to a little below the middle; a blotch on costa before apex, with a smaller one below it, and another on hindmargin below apex; a line of fuscous dashes along hindmargin between the veins; fringe yellow.

Hindwings: wholly yellow.

Underside dull yellow, the forewings suffused with brownish. Face and palpi yellowish, tinged with fuscous; antennae brown; thorax and abdomen yellow.

Expanse of wings : $38 \mathrm{~mm}$.

One $\delta$ from Greymouth, New Zealand.

\section{Scotorythra rara Butler ab. brunnea nov.}

Differs from the type-form, in which the $q q$ are dull fuscous and the $\delta \delta$ blackish, with the stigma, especially in the $q \uparrow$, large and dark, in being red-brown or reddish grey-brown in the $q q$, and slightly darker in the $\delta \delta$; the cell-spot almost obliterated, and all the lines obscure and marked only by dots on the veins.

Two $q f$, one $\delta$, from Oloa, Hawaiian Islands. 


\section{Subfamily FIDONIINAE.}

\section{Callerinnys marginata sp. nov.}

Forewings: yellowish ochreous, tinged in parts with bright ferruginous, and thickly irrorated with dark brown transverse striae; first line at one-third, much curved and waved, forming a dark brown curved spot on the submedian fold; cell-spot dark brown; second line at four-fifths, sinuous, thick, brown-black, contiguous to a thick brown-black shade which opposite the cell is connected with hindmargin; the margin above and below this dark blotch is bright ferruginous; fringe yellow, chequered with black.

Hindwings: more tinged with ferruginous; a brown wavy central line; a postmedian line from costa just beyond central line to anal angle, sinuous, dark brown; marginal area beyond it ferruginous, with dark brown markings, most developed towards costa and hindmargin opposite cell.

Underside bright straw-colour, with the lines and marginal markings bright rich brown. Face and palpi deep yellow; thorax and abdomen yellow, mixed with ferruginous.

Expanse of wings : $36 \mathrm{~mm}$.

One $\&$ from Nias.

This is near C. deminuta Warr., from Padang Rengas, Perak.

\section{Fidonia albigrisea sp. nov.}

Forewings: whitish, the markings dark olive-grey; basal area irrorated with grey, limited by a double curved fascia, the two arms coalescing on the veins forming a series of ocelli; an oblique olive-grey fascia beyond middle, recurved at costa ; its outer edge straight, its inner toothed along the veins, uniting with the linear discal spot, and nearly touching the curves of the basal fascia ; a broad curved submarginal fascia, darker on the veins, its inner edge formed by an exterior lunulate line, the lunules containing a series of pale spots; marginal fascia dark grey; fringe white, mottled with grey opposite the veins.

Hindwings: whitish, speckled throughout with grey, the speckles hardly forming fasciae corresponding to those of forewings, except the central line passing over the dark cell-spot; fringe as in forewings.

Thorax and abdomen whitish, mixed with olive-grey; face whitish, with dark middle bar; palpi dark. Underside duller.

Expanse of wings: $26 \mathrm{~mm}$.

One $\delta$ from West Java.

\section{Subamily SEMIOTHISINAE.}

\section{Acadra acutaria Wlk. ab. olivata nov.}

Markings less distinct than in the type; the outer half of both wings suffused with olive-fuscous; the basal half whiter; the subapical white spots and marginal markings of forewings and the submarginal line of hindwings snow-white.

Fairly common from the Khasias. 
186. Bulonga subcinerea distans subsp. nov.

Forewings: with the outer line much nearer the hindmargin and often recurved towards the costa, the central area being thereby much broader than in the usual form.

In the hindwings also the marginal space is conspicuously narrower than in typical subcinerea.

Two o \& , two $q$ \& , from Cedar Bay, Cooktown, Queensland.

These specimens differ also in colour, being dull brownish grey instead of silvery grey; but I am not sure if this is a natural tint.

The genus Antibadistes, under which I described subcinerea, Nov. Zool. III. p. 142, is identical with Bulonga Wlk., and must sink.

Bulonga schistacearia Wlk. has the fringes dark, whereas in subcinerea they are silvery white.

\section{Evarzia deformis sp. nov.}

Forewings: dull white, suffused with grey, irrorated and striated with fuscous; first line dark brown, fine and indistinct, excurved below costa, then vertical; cell-spot blackish; central line olive-yellow from costa beyond middle, very obliquely waved to inner margin at one-third, where it touches first line; outer line broad, blackbrown, straight and oblique from four-fifths of costa to before anal angle, followed by a line of small brown blotches; a dark cloud towards the elbow ; fringe grey, varied with fuscous, with an interrupted dark line along base.

Hindwings: paler, ochreous, unsuffused with grey as far as the outer line; a dark wavy antemedian line, followed by the dark cell-spot; marginal area blotched with olive-brown towards apex and with a round black blotch beyond outer line between the second and third medians; fringe ochreous yellow, with a strong black crenulate line at base.

Underside whitish, much mottled with blackish, and all the markings blackish; the outer line, which is much thickened on the hindwings, followed by a bright brown fascia, touching hindmargin of forewings above middle and filling up the apex of hindwings. Head, thorax, and abdomen ochreous grey.

Expanse of wings : $36 \mathrm{~mm}$.

One $\delta$ from Batchian, March 1892, collected by Doherty.

The species is remarkable on account of the shape of the forewings; these are elongate, twice as long as wide; the hindmargin is bluntly elbowed at the third median, and thence curved obliquely into the inner margin, which is strongly convex, so that no real anal angle appears. The hindwings are strongly excised on hindmargin between veins 4 and 6,6 and 7 , the three teeth being prominent and acute. The abdomen of the $\delta$ reaches considerably beyond the hindwings.

\section{Gonodela olivescens sp. nov.}

Forewings: white, with fine olive-fuscous striae, and with greyish olive-fuscous markings, varied with minute dull yellow scales; first line curved from costa at onefourth to inner margin near base; second line at two-thirds, angled below costa, then oblique to inner margin before the middle, thick and diffuse; a dark cell-spot; the entire basal area up to this line is more or less obscured by dull scaling; outer line 
from costa at four-fifths, fine, angled outwards towards hindmargin, then oblique and double to inner margin at two-thirds; its costal arm closely followed on costa by an olive blotch, beyond which the apex of the wing is whitish and connected with the paler fascia between the second and outer lines; marginal area suffused with olivefuscous; fringe pale olive-grey, with paler base, and dark patches at end of veins; margin of wing with a row of olive-fuscous triangles.

Hindwings: with ground-colour whiter; an olive-fuscous basal blotch, a broad antemedian and a double postmedian and submarginal fascia ; cell-spot black; fringe and margin as in forewings.

Underside white, with all the markings grey-brown; the costa of forewings and all the veins ochreous. Head, thorax, and abdomen olive-fuscous.

Expanse of wings : $30 \mathrm{~mm}$.

One $\&$ from Kandy, Ceylon, April 1894.

\section{Gonodela perconfusa sp. nov.}

Forewings: whitish, thickly varied with dark fuscous; some dark marks close to base ; a double curved very diffuse inner line before middle, indicated chiefly by dark blotches on costa and towards inner margin; a broad diffuse fascia beyond middle containing an oblique blackish costal blotch, an elongated black blotch below middle, and a blackish blotch on inner margin; marginal area with clouds of dark striae at apex, middle, and anal angle.

Hindwings: with obscure basal fascia; postmedian fascia broad, with large black central blotch.

Underside white, tinged in parts with ochreous yellow, and with the veins yellowish; both wings with dark fuscous cell-spot, thick curved outer line, followed by a broad fuscous fascia mixed with yellowish. Face and palpi dull ferruginous; thorax and abdomen fuscous and grey.

Expanse of wings: $28 \mathrm{~mm}$.

One $\delta$ from Dili, Timor, May 1892 (W. Doherty).

\section{Gubaria albimedia sp. nov.}

Forewings: with the basal fourth and marginal half deep brown-black, with a broad pure white central fascia, not reaching costa ; costa spotted with yellow, most thickly at top of white fascia; cell-spot linear, black; fringe black, with a minute white spot just below costa, and another at middle. The usual dark exterior line can just be traced, forming the edge to the white fascia as far as vein 2 , then running into the dark marginal field and angled below costa; the usual dark costal blotch beyond the angulation blacker than the rest of the dark area.

Hindwings: with base brown-black from one-third of costa to two-thirds of inner margin ; the white fascia very broad at costal end, containing a small black cell-spot; the dark marginal area varied with yellowish scales beyond the exterior line and with black blotches; a pure white blotch on hindmargin from vein 2 to 4 ; a black marginal line; fringe black, with white spots below apex, below vein 7 , and along the white blotch.

Underside like upper ; the dark parts wholly black, except the basal patch, which is varied with yellow scales. Head, thorax, and abdomen above brown-black; abdomen below and at sides yellow. 
Expanse of wings : $40-44 \mathrm{~mm}$.

A pair from South Java, 1500 feet, 1891 (Fruhstorfer).

Related to $G$. niveostriga Warr., but larger and much darker. Of the two examples recorded the $q$ is the smaller.

\section{Gubaria niveostriga sp. nov.}

8. Forewings: purplish grey, tinged with fuscous; a snow-white central fascia narrowing towards inner margin, with the edges quite straight, the costal end narrowly fuscous with a few scattered striae below; the discal dot black; outer line thick, black, angled below costa, and forming, below the median, the outer edge of the white fascia, followed by a thick dark fuscous cloud; a darker spot on costa beyond it, followed by a small white spot towards apex below costa ; fringe white at apex and below middle, the rest fuscous.

Hindwings: with the central fascia narrowing to a point before reaching inner margin; the black outer line which bounds it is followed by black blotches mixed with yellowish ochreous scales; a white blotch, varying in size, on hindmargin below the middle, the purplish fringe being white beyond it.

Underside of both wings with basal area yellow, edged by a dark brown line, which represents the inner edge of the white central fascia ; outer area dark fuscous, with the small subapical spot of forewings and the marginal spot of hindwings white. Head, thorax, and base of abdomen purplish fuscous; anal half of abdomen with the sides, and all the underside and legs yellow.

Expanse of wings : $40 \mathrm{~mm}$.

Three $\delta$ from Dili, Timor, May 1892, collected by Doherty; and two from Oinainisa, Dutch Timor.

\section{Gubaria amplata sp. nov.}

The forewings above are like those of niveostriga Warr., but in the hindwings the dark basal area barely reaches to half the costal and inner margins, and in consequence the central white band, instead of being narrowed to a point at two-thirds from the costa, as in niveostriga, becomes curved and very much wider than that of the forewings, while the marginal white blotch is much increased in size. On the underside the dark basal areas of both wings are hardly tinged with yellow, and the abdomen above is fuscous to the tip. The cell-spot of the hindwings is distinct, lying in the white fascia.

One of from Dili.

\section{Luxiaria calida sp. nov.}

Forewings: brownish ochreous, dusted with dark atoms; a dark cloudy cell-spot, through which a faint curved darker first line can be traced; exterior line slightly sinuous, marked by dark dots on veins; preceded by a paler ochreous fascia, and followed by a fascia of the ground-colour, of which the outer edge is dentate, and bounded by the obscure submarginal line, the marginal space again being paler ochreous; a row of dark marginal spots; fringe paler.

Hindwings: like forewings, but the outer third darker than the basal area, and with traces of a dark central line; hindmargin strongly dentate. 
Underside paler, with fuscous transverse strigae; the markings plainer; the outer line followed towards costa by a ferruginous fascia. Face and palpi dark brown; thorax and abdomen concolorous with wings.

Expanse of wings: $42 \mathrm{~mm}$.

One of from South Java, 1500 feet, 1891 (Fruhstorfer).

\section{Luxiaria punctata sp. nov.}

Forewings : straw-colour, dusted with ochreous and pale fuscous ; first line near base, very indistinct, marked by spots on the veins; cell-spot large, brown, followed by an indistinct waved central line; exterior line at three-fourths, dull rusty, accompanied by dark dots on veins, with a small brown blotch on inner margin before it; submarginal line wavy, hardly paler, preceded by a slight brown cloud opposite the cell; a marginal row of black spots on the veins; fringe clear ochreous.

Hindwings: the same, the cell-spot small and dark, followed by a grey central line.

Palpi and face ochreous below, brown above; thorax and abdomen ochreous, dusted with darker; abdomen with dark dots along back. Underside paler, with the central and outer lines bright ferruginous, the latter followed on forewings by a bright ferruginous, dentate-edged cloud from costa to middle, which is fuscous-tinged opposite the cell ; hindwings with a fuscous cloud on submarginal line opposite cell.

Expanse of wings : $34-36 \mathrm{~mm}$.

Two $q$ from Bandong, Java.

The smaller of these examples, though more worn than the type, has the dots denoting the first and outer lines enlarged into a distinct series of brown spots, those on costa and inner margin swollen; the marginal spots and clouds on the submarginal lines are also darker and more conspicuous.

\section{Nadagarodes straminea.}

\section{Luxiaria (?) straminea Warr., Nov. ZooL. III. p. 303.}

When describing the $q$ of this species from Fergusson Island I queried the genus. I have now met with a $\delta$ from Amboina (agreeing with the $q$ in all respects, except in not having the dark blotch heyond cell), which, having short pectinated antennae and non-crenulate hindwings, must be placed in Nadagarodes.

\section{Semiothisa angustimargo sp. nov.}

Forewings: whitish ochreous, semitransparent, rather thickly dusted with fine black atoms; the costa yellowish, more densely scaled; the lines pale fuscous; first at one-fourth, forming two outward curves; second just beyond middle, outcurved above median, and obtusely bent on the submedian fold; traces of a bent line immediately preceding it and passing over the black linear cell-spot; exterior line at four-fifths of costa, angled strongly below apex, then straight, oblique, and double, dark fuscous, to inner margin just before anal angle; the narrow marginal area fuscous grey ; fringe grey, darker along the excision.

Hindwings: with a thick straight central line passing over the small black cell-spot; outer line and margin as in forewings. 
Underside like upper, but the outer line diffusely thickened with brown, the marginal area beyond it whitish and glossy. Head, thorax, and abdomen concolorous.

Expanse of wings : $32-36 \mathrm{~mm}$.

Three $\delta \delta$ from Oinainisa, December 1891 (W. Doherty).

\section{Semiothisa fusca sp. nov.}

Forewings: dull fuscous grey, with darker specks and striae; first line very indistinct, at one-fourth; a thick vertical central shade beyond the dark cell-spot; outer line formed of regular grey lunules, followed by a slightly darker fascia edged with three brown spots at costa, and with some brown spots below the middle; fringe concolorous, with an interrupted dark line at base.

Hindwings: the same.

Underside clear white, strigulated with fuscous towards base, with all the marks very distinct and brown; the discal spots deep black. Head, thorax, and abdomen hoary grey.

Expanse of wings: $32-40 \mathrm{~mm}$.

In some numbers from Cedar Bay, Cooktown, Queensland (A. S. Meek).

The forewings have the hindmargin entire, not excised below the apex, very faintly crenulate; that of the hindwings is strongly crenulate.

\section{Semiothisa subcastanea sp. nov.}

Forewings: whitish ochreous, densely dusted with fuscous atoms; the base and costa tinged with brownish; first line and cell-spot not marked; second line indistinct, at three-fourths, starting from a dark costal spot, angled below costa, then faintly waved; followed by a grey-brown fascia, edged on costa by an oblique red-brown blotch; marginal area greyish brown; two whitish subapical streaks, the lower one running in above vein 6 to its origin; marginal spots black; fringe ochreous, except along the subapical excision, where it is dark brown, as is the margin itself.

Hindwings: like forewings, but with a black cell-spot.

Head, face, palpi, thorax, and abdomen whitish, speckled with fuscous. Underside white, with blackish coarser speckles; the outer line darker; the outer third, especially the fascia, chestnut-brown; the veins ferruginous; apex of forewings and submarginal space on hindwings varied with white black-spotted blotches.

Expanse of wings: $36 \mathrm{~mm}$.

One $\&$ from Bandong, Java.

\section{Tephrinopsis gen. nov.}

Under Tephrina Guenée placed together species having simple antennae in the $\delta$ and species having them pectinated. I propose to separate the former, those with simple antennae, under the above name, with Tephrinopsis parallelaria Wlk. for type.

\section{Tephrina munda sp. nov.}

Forewings: whitish, thickly dusted with grey-brown striae; the costa ochreous, dotted with fuscous; inner line brown, curved, obsolescent towards costa; second line 
at two-thirds, faintly sinuous and irregular, closely followed by a fuscous shade, with darker patches between the veins; a row of brown marginal dots between the veins; fringe pale; a blackish distinct cell-spot.

Hindwings: the same, without first line, and the submarginal shade very faint.

Underside with a yellowish tinge and a marginal cloud. Head, thorax, and abdomen whitish; collar, face, and palpi tinged with rufous.

Expanse of wings: $26 \mathrm{~mm}$.

A pair from Sumba, October 1891 (W. Doherty).

\section{Tephrina subocellata sp. nov.}

Forewings: pale ochreous, dusted and suffused with olive-fuscous; costa dotted slightly with fuscous; three fasciae parallel to hindmargin; first at one-fourth, second at one-half, both fuscous-olive above median vein, brown-black and thickened below it; the lower part of the central fascia is twice as broad as the first; its upper half contains a pale darker-edged ocelloid cell-spot; third fascia sinuous, fuscous-olive throughout, edged inwardly by a twice-curved brown-black band which does not reach the costa; marginal area suffused with fuscous-olive strigae; marginal line brown ; fringe ochreous.

Hindwings: with a central fuscous-olive streak containing the dark cell-spot and not reaching the costa ; the exterior fascia diffuse externally and edged internally by a nearly straight brownish line.

Head, thorax, and abdomen ochreous. Underside pale ochreous, with the markings dull olive-brown.

Expanse of wings : $24 \mathrm{~mm}$.

One $\delta$ from South Othman, Arabia.

\section{Thamnonoma insularis sp. nov.}

Forewings: dull straw-colour, dusted with ochreous and fuscous atoms; the three lines starting from three outwardly oblique brownish grey costal blotches, at one-fourth, one-half, and two-thirds respectively; all angled below costa and then inwardly oblique, but very ill defined; a dark curved mark before the subapical excision ; fringe straw-colour, with dark spots at end of veins and along the excision.

Hindwings: with the two outer bands continued, one antemedian, the other postmedian; a black cell-spot.

Underside like upper, but the forewings suffused with pale ferruginous. Head, thorax, and abdomen concolorous.

Expanse of wings : $36 \mathrm{~mm}$.

One $\delta$ from Lifu.

\section{Petrodava sordida sp. nov.}

Forewings: dull fawn-colour, speckled with dark fuscous; the first and central lines very indistinct, with a slightly darker shade before each; both angled below costa, the central also angled on the median and lower veins, and running obliquely inwards to inner margin at middle; exterior line dark brown, angled below the costa, and thence running straight and oblique but slightly wavy to inner margin at twothirds; marginal area and fringe darker fawn-colour, the submarginal line indicated 
by some still deeper clouds; the area between the inner and outer lines slightly paler than the rest of wing; cell-spot dark.

Hindwings: still paler, more ochreous; a curved outer line brown, followed by a brown shade and an interrupted cloudy submarginal line; fringe dark brown; cell-spot distinct, black.

Head, face, thorax, and abdomen pale ochreous. Underside bright yellow, mottled with tawny; a wavy indistinct central line and a distinct thick red-brown outer line on both wings ; marginal area fulvous, deeper on hindwings; the lower part of hindmargin remaining yellowish; apex of forewings dull whitish.

Expanse of wings: $48 \mathrm{~mm}$.

One $\delta$ from Humboldt Bay, New Guinea, taken in September by W. Doherty.

Nearest to $P$. khasiana Swinh., but not so large, and more sombre-coloured above.

\section{Xenoneura gen. nov.}

Forewings: narrow; costa straight, convex only just before apex; apex blunt; hindmargin obliquely curved into the inner margin, which is convex; the anal angle rounded off.

Hindwings: broad; hindmargin strongly erenulate in the upper half.

Abdomen of $\delta$ long and slender, the claspers strongly developed; antennae of $\delta$ pectinated for two-thirds; palpi porrect, the second joint thick and hairy, the third blunt; tongue present; hind tibiae of $\delta$ much swollen, with four short spurs; fovea of forewing with a dark thickened scar.

Neuration: forewings, cell half the length of wing; discocellular vertical for two-thirds, then shortly bent outwards and oblique; first median nervule at one-half, second before end of cell, third from end; lower radial from the angulation of the discocellular, and therefore below the middle; upper radial from top end of cell; last three subcostals stalked, first and second coincident.

Type: Xenoneura tephrinata sp. nov.

\section{Xenoneura tephrinata sp. nov.}

8. Forewings: whitish ochreous, with numerous fuscous transverse striae; costa dotted with dark; the lines pale brown; first at one-fourth, outcurved below costa ; second at three-fourths, also outcurved below costa; marginal area rather darker; submarginal line pale, indistinct, preceded on costa by a dull reddish cloud and by a fuscous cloud below ; basal line fine, dark; fringe concolorous; cell-spot blackish, followed by a thick brownish central shade.

Hindwings: like forewings, with no basal line, and the outer line waved; the shade before the submarginal line distinctly reddish; a fuscous marginal shade opposite the cell ; marginal line blackish, strongly crenulate; fringe pale ochreous, with dark mottlings at the teeth.

Underside whiter, with the markings more expressed; marginal shade of the hindwings blackish. Head, thorax, and abdomen concolorous; antennae dark.

Expanse of wings : $32 \mathrm{~mm}$.

One $\delta$, one $q$, from Geraldton, Cairns, and Cedar Bay, Cooktown, Queensland.

The $q$ is almost wholly suffused with brownish grey, with the markings obscured; underside with the colouring very much brighter than in the $\delta$. 


\section{SubFamily ENNOMinaE.}

\section{Capasa viridifascia sp. nov.}

Forewings: greyish fawn-colour, without mottling or suffusion; a central fascia angled on the median; its costal third velvety black, the rest very delicate pale green, with a slightly darker olive-green centre; a dark brown triangular spot on costa at three-fourths; fringe concolorous.

Hindwings: with the green fascia narrower, slightly curved, and edged externally with deep black; costa broadly, inner margin narrowly, yellow.

Underside of forewings deep vinous red, becoming yellow towards costa; the costal spots brown; the fascia, inner margin, and hindmargin grey-brown. Hindwings deep orange-red, with a dark grey blotch at apex and anal angle, and a black fascia from upper angle of cell to anal angle; palpi bright orange, the tips and the tongue black; face dark brown-red; vertex, antennae, thorax, and abdomen concolorous with the wings.

Expanse of wings : $36 \mathrm{~mm}$.

Six $\delta$ o from Humboldt Bay, New Guinea, collected by Doherty, September and October 1892 .

Akin to $C$. incensata Wlk., but smaller and paler.

\section{Heterodisca gen. nov.}

8. Forewings: twice as long as broad; the costa arched for basal third, then straight, becoming convex only just before apex; hindmargin curved.

Hindwings: with both angles and the hindmargin rounded.

Palpi porrect, slightly upcurved, terminal joint short ; tongue present ; antennae of $\delta$ simple, thick, closely lamellate; hind tibiae much swollen, with four short spurs; hind tarsi very short; frenulum strong.

Neuration: forewings, cell about half as long as wing; discocellular angulated, the upper arm oblique outwards, the lower vertical ; first median at three-fourths, second shortly before end, third from end of cell; lower radial from the angulation of the discocellular; upper radial stalked with the last three subcostals from end of cell; first and second subcostals stalked, anastomosing with costal at a point, the second afterwards anastomosing with the stalk of third and fourth. Hindwings without radial; the two subcostals and last two medians from the ends of cell.

Type: Heterodisca scardamiata sp. nov.

\section{Heterodisca scardamiata sp. nov.}

Forewings: orange-yellow, thickly dusted with reddish orange striae; first line at one-fourth, nearly vertical, red-brown, with lustrous leaden scales on it; a round brown cell-spot; second line from costa shortly before apex to two-thirds of inner margin, straight and oblique, edged outwardly by a line of lustrous leaden scales; a fine dark red-brown marginal line; fringe concolorous.

Hindwings: with a straight brown central line, edged with lustrous scales; traces of a much outcurved submarginal line, indicated by dark dots on the veins. 
Underside dull ochreous yellow, with all the markings showing through indistinctly ; forewings with a line of vein-dots beyond outer line, as in hindwings, but less strongly outcurved. Palpi, thorax, and abdomen reddish orange ; face and collar brighter.

Expanse of wings : $34 \mathrm{~mm}$.

One $\delta$ from Humboldt Bay, New Guinea, October, taken by W. Doherty.

\section{Hyposidra maculipennis sp. nov.}

Forewings: pale fawn-colour, slightly rufous-tinged in parts, and dusted with blackish atoms; a small dark cell-spot; a straight oblique rufous line from middle of costa to middle of inner margin; outer line very faint, wavy, and joining central line on inner margin ; a macular submarginal shade of purple blotches, one on costa, another opposite the cell, and a large one at anal angle; a dark blotch on costa before apex ; fringe concolorous. The bindmargin is bluntly rounded and protuberant, with slight projections at the veins, from apex to lower radial, thence obliquely curved.

Hindwings: with large round black cell-spot, preceded by the straight line and followed by a denticulate line nearly in the middle; the blotches of the submarginal line distinct on the inner half, faint towards apex; fringe concolorous; hindmargin strongly waved, with a blunt projection in middle.

Underside much darker, suffused and speckled with fuscous; face and palpi fuscous; thorax and abdomen concolorous with wings.

Expanse of wings: $84 \mathrm{~mm}$.

One $\&$ from the Solomon Islands (Capt. Cayley Webster).

\section{Hyposidra nigricosta sp. nov.}

Forewings: brownish ochreous, speckled with black; costa brown, mottled with pale ochreous; a broad subcostal black-brown stripe with indented lower edge, running through to apex and traversed by the pale submarginal line; the lines rich brown, first curved from costa at one-fourth to inner margin near base; discal spot blackish, lying in the broadest part of the subcostal stripe; a nearly straight brown central line to inner margin in middle; a dark brown wavy and dentate outer line from costa at three-fourths to inner margin just beyond central line, followed beneath costa by another brown line; submarginal line indistinct; a brownish cloud at anal angle; fringe brown.

Hindwings: dark brown, with a strongly dentate postmedian line, pale with dark edges; discal spot black; fringe dark brown.

Underside dark black-brown, becoming paler brown towards the margin; all the lines dark.

Expanse of wings: $60 \mathrm{~mm}$.

One $\delta$ from Batchian, March 1892, collected by Doherty.

Akin to infixaria Wlk., but much larger.

208. Hyposidra variabilis Warr. ab. tetraspila nov.

Among several examples of this species from Humboldt Bay of Doherty's collecting, there occur two forms so strikingly different as to deserve describing. The form which I call tetraspila is of a rich pinkish fawn-colour; the inner and outer lines are 
only slightly marked, but a broad straight deep brown central line is conspicuous just beyond the discal dot; the apical black patch is strongly marked; and beyond the exterior line of both wings below the median is a round black blotch. This aberration is a development of that described by me as nubilosa from Fergusson Island.

\section{ab. innotata nov.}

The other form is as inconspicuous as tetraspila is striking. Both wings are dull fawn-colour, speckled with dark fuscous dots, with no markings except the black cell-spots, and in the forewings some brown interrupted spots indicating the exterior line towards the costa. The short dark lines on the inner margin of hindwings above the anal angle are present, but very inconspicuous.

The two examples were taken in September and October 1893.

Ischalis Wlk. XXVI. p. 1750.

8. Forewings: with costa shouldered at base, then straight, with a faint insinuation, to apex; apex shortly produced; hindmargin toothed at veins 4 and 6 , indented between, oblique below the lower tooth to anal angle, but with a slighter tooth at vein 3 .

Hindwings: with hindmargin rounded. wings,

In the $q$ the hindmargin of hindwings is quite as strongly dentate as in fore-

Palpi porrect, rather long; forehead tufted; antennae lamellate, thickened towards base, subserrate; abdomen of $\delta$ very long; inner half of hindwings of $\delta$ beneath clothed thickly with long furry hair.

Neuration: forewings, cell two-thirds of wing; the median and subcostal veins both bent inwards at extremity; first median at three-fourths, second before end, third from end of cell; radials normal; last three subcostals stalked, second anastomosing with the stem of third and fourth towards apex, forming a very long areole; all three then separating together; first subcostal free.

I have given this diagnosis of Ischalis here because Walker, who described the type-species twice, first as Selenia gallaria and afterwards as Ischalis thermochromata, had only $q f$, while Mr. Meyrick, who described the genus afresh under the name of Stratocleis, did not describe or notice apparently the peculiarity of the underside of the $\delta$ hindwing. It is almost certain, judging from the description, that Guenée's Epione incaria is the same species, although he gives Tasmania, perhaps by an oversight, as habitat.

\section{Omiza columbaris sp. nov.}

Forewings: pale lilac-grey, with very fine dark transverse striae; the lines purple; first from costa at two-fifths to inner margin at one-fourth, slightly curved; second from costa at four-fifths, acutely angled below apex, then faintly curved to inner margin before middle, the interval between the two lines there being narrow; this space is filled in with deep green; discocellular edged with purple; a flattened pale grey costal spot before apex; fringe rufous.

Hindwings: with costal area pale; the basal one-third rufous olive, edged by a straight purplish line; fringe and hindmargin rufous. 
Underside of forewings yellow along costa to outer line, |white along inner margin; the rest of the wing deep vinous red; the outer line and edge of ocellus darker; hindwings deep yellow, with a few large scattered specks and the discal spot red. Palpi and face olive; head, thorax, and abdomen pale grey; vertex and antennae whiter.

Expanse of wings : $38 \mathrm{~mm}$.

One $q$ from South Java, 1891, 1500 feet (Fruhstorfer).

\section{Omiza subaurantiaca sp. nov.}

Forewings: dark purplish brown, strigulated with darker; the lines chocolate; first from just before middle of costa, oblique and somewhat irregularly curved, to inner margin at one-third; second from three-fourths of costa, angled outwards towards hindmargin, then oblique and irregularly waved to inner margin at middle; the central space therefore much narrowed below, as in galbulata Feld.; this space is slightly deeper coloured than the rest of the wing, and towards the costa sometimes varied with dark green; cell-spot annular, edged with chocolate; a dark smoky black blotch on inner margin before anal angle, much more obscure than that in irrorata Moore, and with a metallic lustre; fringe chocolate-brown.

Hindwings: with the fascia produced narrowly across the centre, the outer edge alone distinct; costal area pinkish, not so broadly red as in abstractaria Wlk.; towards the anal angle is a large blotch of shining scales.

Underside of forewings deep orange at base and along costa and inner margins, becoming deep brown-red from centre to hindmargin; hindwings bright orange, with some red-brown spots along costa and in apical region; fringes of both wings lustrous. Palpi orange; face brown; vertex, thorax, and abdomen olive-grey.

Expanse of wings : $36 \mathrm{~mm}$.

Six $\delta$ of from Dili, Timor, collected in May by W. Doherty.

Nearest to $O$. abstractaria Wlk., but quite distinct from any Indian form.

\section{Polyacme gen. nov.}

Forewings: with costa straight, curved at base; apex produced, minutely acute; hindmargin strongly dentate at vein 6 , and bidentate at 4 and 3 ; then oblique and crenulate to anal angle, which is distinct.

Hindwings: strongly dentate at ends of all the veins.

Palpi with second joint upcurved, third short; antennae of $q$ simple.

Neuration: forewings, cell about half as long as wing; discocellular oblique outwards; first median at two-thirds; second and third from end of cell; radials normal; last four subcostals stalked; first anastomosing with costal. Hindwings with first subcostal and second median from before end of cell.

Type: Polyacme dentata sp. nov.

\section{Polyacme dentata sp. nov.}

Forewings: yellowish ochreous, varied with fuscous and ferruginous striae; costa dotted with brown; first line at one-fourth, irregularly curved, and indicated by small spots of black scales; the area within it sometimes brownish; an oblique diffuse ferruginous central shade, touching on its inner side the discal ring ; marginal 
two-fifths dark brown except along costa, the inner edge sinuous and preceded by a sinuous row of dots on veins; exterior line at three-fourths, marked by black dots above, and followed below by a blackish shade, curved outwards above middle and inwards below it; submarginal line similarly eurved, and indicated by dark blotches, of which the two opposite the cell are prominent and black; fringe deep brown.

Hindwings: like forewings, but the central shade passes inside the cell-ring; submarginal line pale ochreous, edged inwardly with brown, bluntly angled opposite the cell.

Underside the same, except that the brown marginal area extends to the costa, leaving only a small apical blotch white; a greyish white blotch on hindmargin of both wings below the third median. Head, thorax, and abdomen all ochreous, dusted with dark atoms.

Expanse of wings : $38-42 \mathrm{~mm}$.

Two $q q$ from Lifu.

\section{Prionia excavata sp. nov.}

Forewings: reddish, much dusted with blackish; the costa dotted and spotted with black, the interspaces paler; first line diffuse and indistinct, oblique inwards from a costal blotch before middle, joined in midwing by a dark shade from a costal blotch at one-fourth; cell-spot dark, linear ; exterior line from dark costal blotch at three-fourths, exeurved and denticulate, incurved before inner margin, followed between the median nervules by two pale ochreous yellow patches; fringe dark red-brown.

Hindwings: orange-yellow, paler along costa; the hindmargin and inner margin diffusely edged with reddish and fuscous scales, the extreme inner margin remaining clear yellow.

Palpi reddish, the terminal joint dark fuscous; face dull reddish, with a small whitish dot at top; vertex whitish in front, reddish behind; thorax and abdomen reddish, mottled with grey; shaft of antennae white. Underside of forewings dull reddish, towards base tinged with orange, with the two yellow submarginal patches distinct; hindwings orange, with margin reddish.

Expanse of wings : $32 \mathrm{~mm}$.

One $f$ from Nias.

The forewings have a strongly developed prominence below the middle of hindmargin, below which the margin is very oblique and incurved; the hindmargin of hindwings is strongly excised from anal angle to end of second median nervule; veins 10 and 11 of forewings are shortly stalked.

Allied to, but distinct from, P. multidenteta Warr., also from Nias. 


\section{$2 \mathrm{BHL}$ Biodiversity Heritage Library}

Warren, William. 1896. "New species of Drepanulidae, Thyrididae, Uraniidae, Epilemidae, and Geometridae in the Tring Museum." Novitates zoologicae : a journal of zoology in connection with the Tring Museum 3, 335-419. https://doi.org/10.5962/bhl.part.5427.

View This Item Online: https://www.biodiversitylibrary.org/item/22554

DOI: https://doi.org/10.5962/bhl.part.5427

Permalink: https://www.biodiversitylibrary.org/partpdf/5427

\section{Holding Institution}

Natural History Museum Library, London

\section{Sponsored by}

Natural History Museum Library, London

\section{Copyright \& Reuse}

Copyright Status: Public domain. The BHL considers that this work is no longer under copyright protection.

This document was created from content at the Biodiversity Heritage Library, the world's largest open access digital library for biodiversity literature and archives. Visit BHL at https://www.biodiversitylibrary.org. 